\title{
فاعلية برنامج إرشادي مقترح في تحسين جودة الحياة و اكتساب أساليب مو اجهة أحداث الحياة الضاغطة لطالبات الجامعة
}

\section{إعداد}

د.جيهان عثمان محمود

مجلة الدراسات التريوية والاساتية ـ كلية التربية ـ جامعة دمنهور الججلا الخامس العدد (1) لسنة 2013 
فاعلية برنامج إرشادي مقترح في تحسين جودة الحياة واكتساب أساليب مواجهة أحداث الحياة الضاغطة لطالبات الجامعة فئرة

د.جيهان عثمان محمود

\section{ملخص الار اسة :}

تهدف الدر اسة الحالية لإعداد برنامج إرشادي مقتر ح لتحسين جـودة الحيــاة و الكشف عن أثر البرنامج علي أساليب مواجهة احداث الحياة الضاغطة لدي الداي طالبات الجامعة

أدوات الار استة الجعة :

استخدم الباحثة في الدراسة الأدوات التالية :

1.مقياس جودة الحياة إعداد الباحثة .

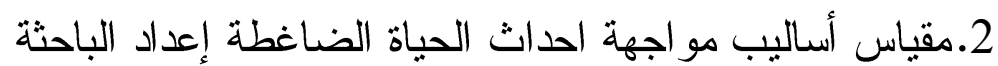

3. برنامج إرشادي مقتر ح لتحسين جودة الحياة إعداد الباحثة .

\section{عينة الار استة :}

طبقت الدر اسة علي عينة من طالبات كلية التزبية جامعة طيبة

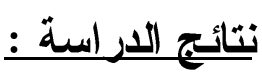

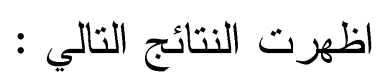

1. يوجد فرق ذا دلالة إحصائية بين متوسطي رتب درجــات المجمــو عتين

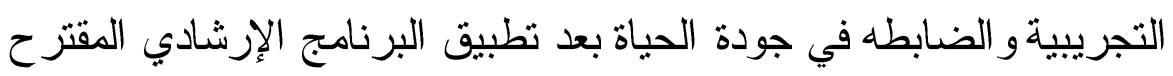

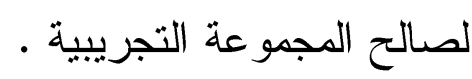

2. يوجد فرق ذا دلالة إحصائية بين متوسطي رتب درجـــات المجمـو عتين

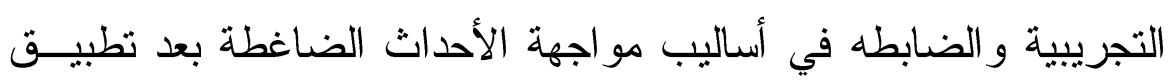

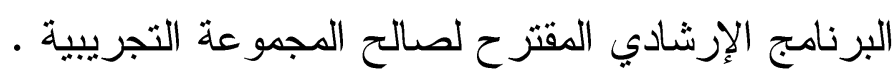
3. لا يوجد فرق ذا دلالة إحصائية بين متوسطي رتب درجيـات القياسـين الإدين

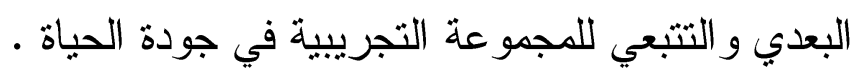


4. لايوجد فرق ذا دلالة إحصائية بين متوسطي رتب درجات القياسين البعدي

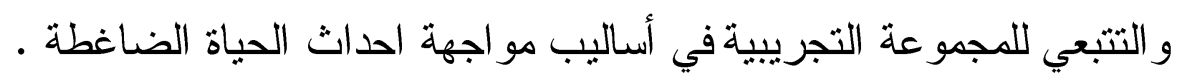
مقدمة:

أصبح الإهنمام بجودة الحياة توجهاً تربوياً ونفسياً في المقام الأول، ولــللك

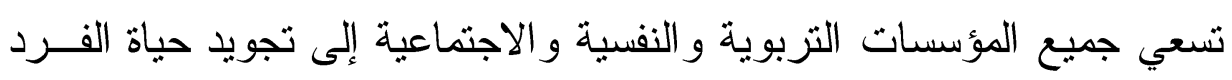

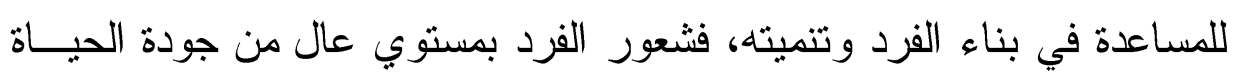
من شأنه أن يؤثز إيجاباً علي مستوب أدائه في مجالات التهات الحياة المختلفة.

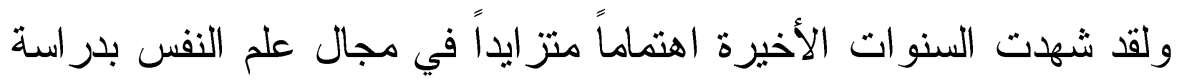

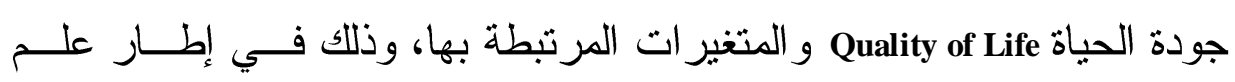

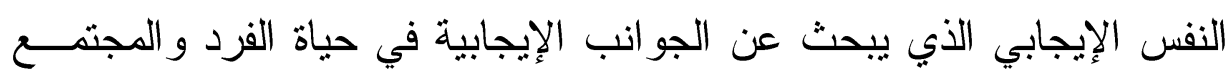
ليصل بهما إلى الرفاهية.(هشام عبد الله، 2008: 139)

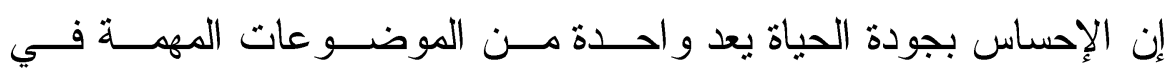

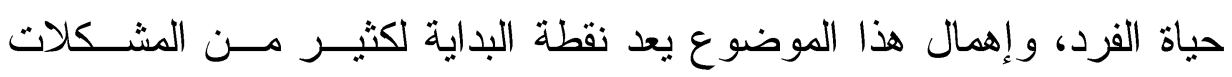

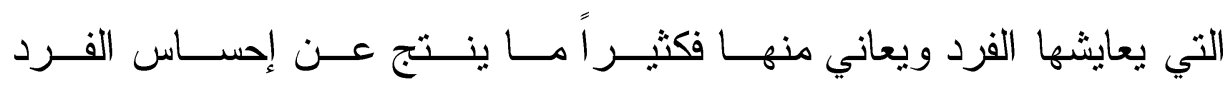
بانخفاض مستوي جودة الحياة مشــكلات و اضــطر ابات نفســية و اجتماعيــة (سعيد عبد الرحمن محمد، 2011: 217)

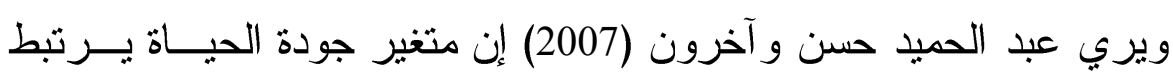
بمتغير ات نفسيه إيجابية و عديدة كالشعور بالسعادة و الرضا عن الحياة و التفاؤل

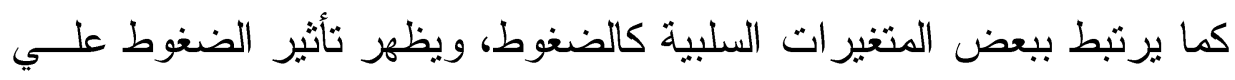

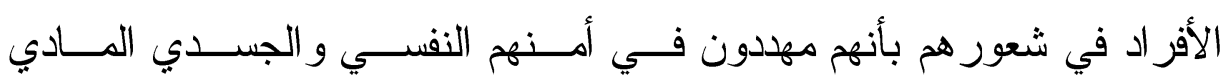
و الإجتماعي، مما دفع الكثير من الباحثين إلى البحث عن العو المل التي تساعد

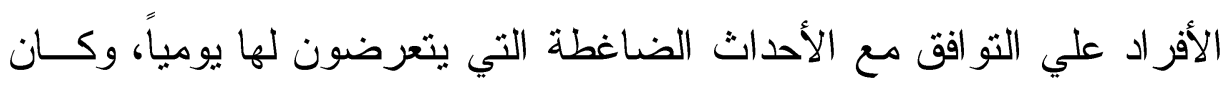

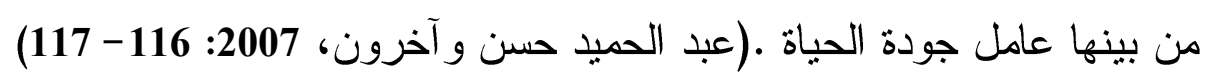


وتعد فئة طلاب الجامعة أكثر فئات المجتمع تعرضــاً للضــغوط المختلفــة

الإكاديمية و الإجتماعية و النفسية و الإقتصادية. (Constance,H., 2004: 515) و انطلاقاً من إن الصحة النفسية للطالب الجامعي ركيزة أساسية فـــي الإنتــاج و التقام، وأن أي مشكلات أو ضغوط حياتية يتعرض لها الطالب في أنثاء حياته الجامعية تترك آثار ها السلبية على صحته النفسية و الجسمية، تؤثر على نجاحه

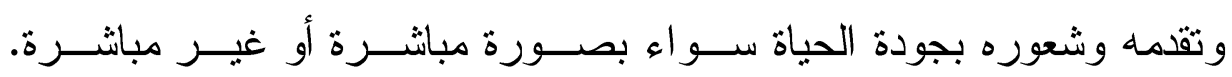

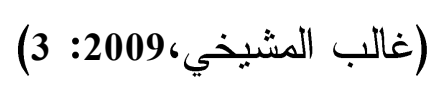

وتعد البيئة الجامعية مهمة في تحديد مستوي جودة الحيــاة لــدى الثـــباب،

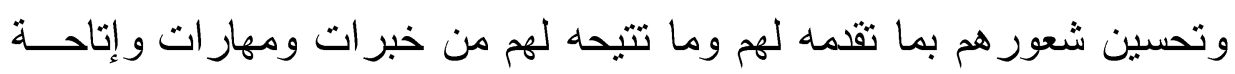

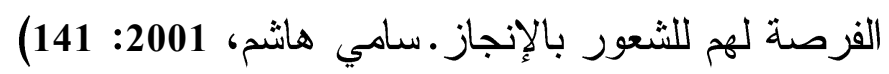

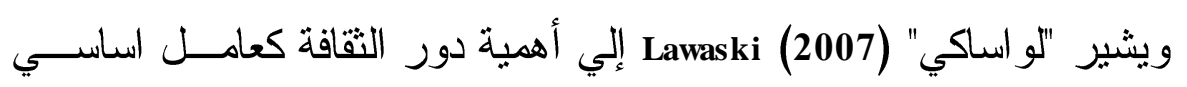

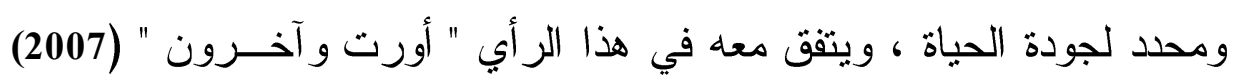
Orte., et, al

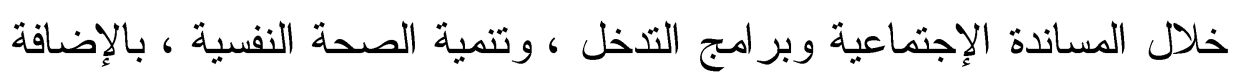

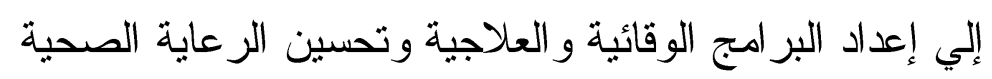

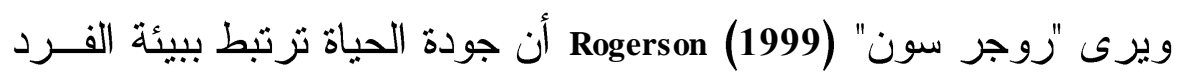

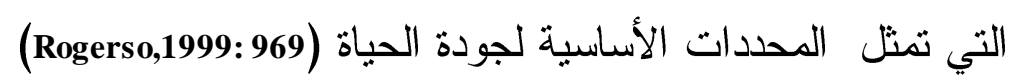
كما يري "الونجست" (2008) أن جودة الحياة تتحقق من خلال قدرة الفرد على إثباع حاجات الصحة النفسية، مثل الحاجات البيولوجية و العلاقات الإيجابية و الاستقر ار الاقتصادي، والقدرة على مقاومة الضغوط المختلفة. و انطلاقاً مما سبق عرضه تسعى الار اسة الحالية إلى محاولة تحسين جودة الإنة

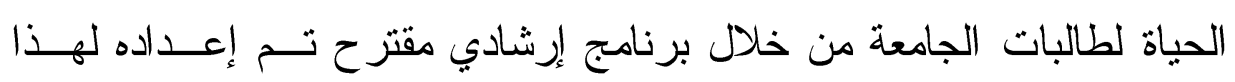
الغرض و اكتشاف أثزه إيضا أساليب مو اجهة أحداث الحياة الضاغطة. 


\section{مشكية اللار اسية:}

أن الشعور بجودة الحياة شيء نسبي يختلف من فرد لآخر اســتناداً إلــى المعايير و المحدات التي يعتمدها الأفر اد لتقويم حياتهم ومتطلباتها، التي تتأثز

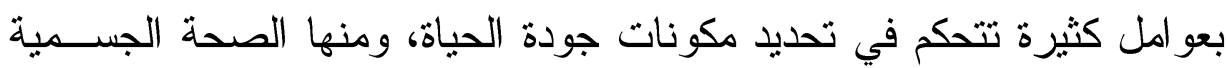
و النفسية و القدرة على اتخاذ القرار ات و التحكم و إدارة الظروف المحيطة سو اء الإقتصادية أو الإجتماعية، وكذلك المعتقدات الدينية و الثقافية، ويحدد الفرد من ون

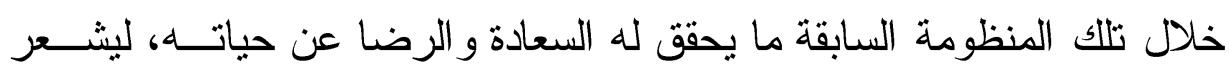
بجودة الحياة. وقد انبتقت مشكلة الدر اسة من خلال الدراسة الإستطلاعية التي قامت بهــا

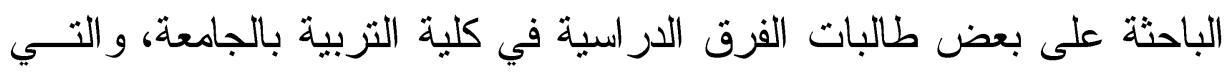
أثنارت نتائجها إلى وجود بعض المشكلات لدى الطالبات من انخفاض مستوي

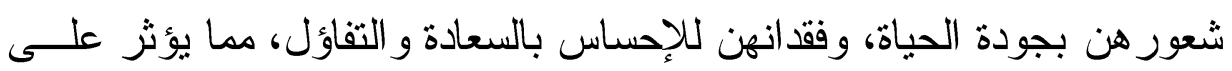
فاعليتهن الذاتية ورضاهن عن الحياة. وفي ضو ء ما اقتزحته وأوصت به بعض الدر اسات السابقة التي أكدت على ألى

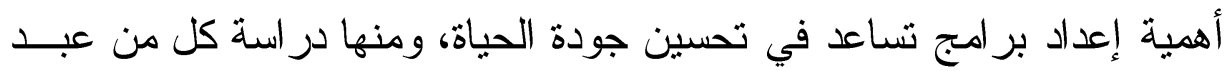

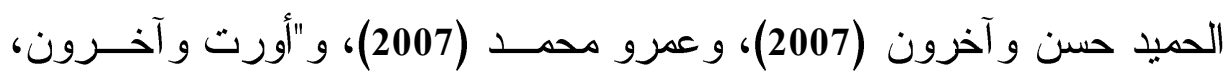

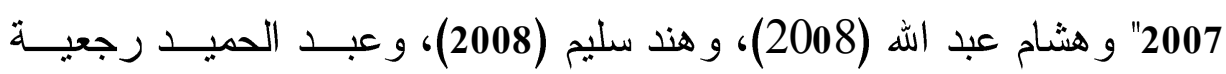
(2009)، هويدا حنفي وفوزية الجمالي (2010)، ومحمود منسي و وعلى كـاظم

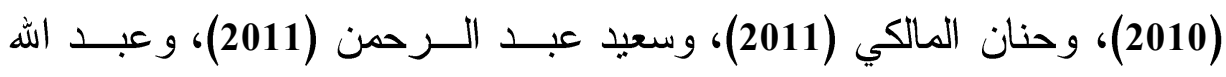

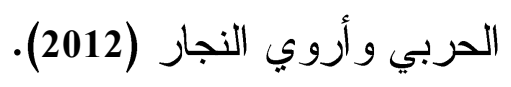
مما دفع الباحثة إلى تتاول الموضوع لأهميته،بالإضافة إلي ندرة الدراسات

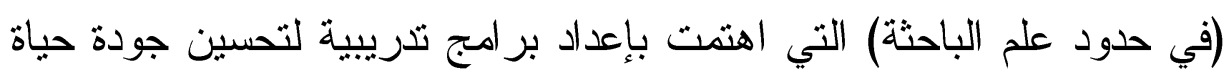
طلاب الجامعة. 


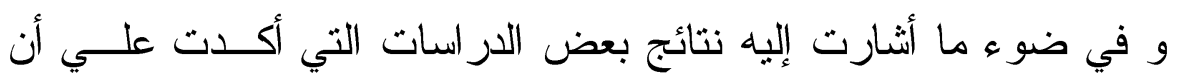

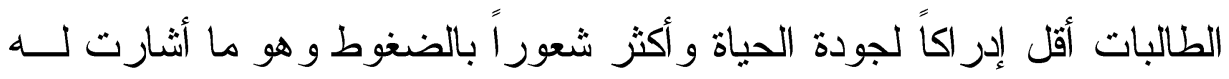
دراسة دراسة عبد الحميد حسن و آخرون (2007)،و عبد الحميد رجيعه (2009)

$$
\text { ،هويدا حنفي وفوزية الجمالي (2010). }
$$

\section{وتحاول الاراسة الحالية الإجابة عن الأسئلة التالية:}

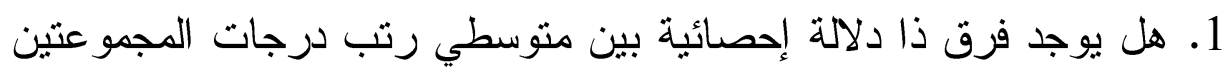

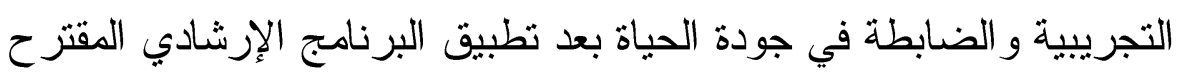

$$
\text { وما وجهة هذه الفروق إن وجدت؟ }
$$

2. هل يوجد فرق ذا دلالة إحصائية بين متوسطي رتب دهد درجات المجمو عتين

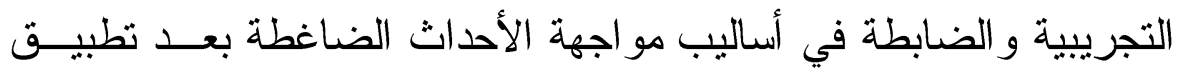
البرنامج الإرشادي المقترح. وما وجهة هذه الفروق إن وجدت ؟

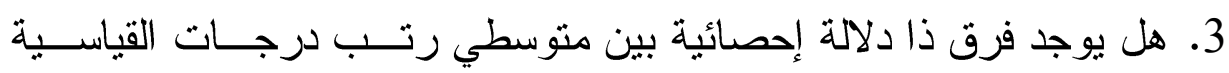

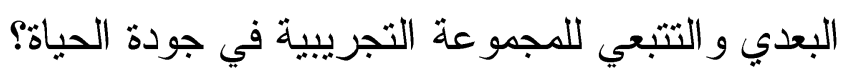
4. هل يوجد فرق ذا دلالة إحصائية بين متوسطي رتب درجـات القياسـين فئن البعدي و التتبعي للمجمو عة التجريبي في أساليب مواجهة أحسـداث الحيــاة الضاغطة ؟

\section{• أهمبة اللار اسة:}

تستهد الار اسة أهميتها من أهمية وحداثة المتغيرات التي تنتاولهــاكويمكن تحديد أهمية الدر اسة في النقاط التالية: 1. تسهم في تحسين إدر الك الطالبات لجودة الحياة.

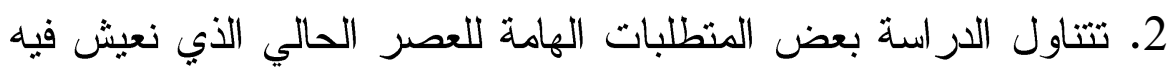
و هو جودة الحياة. 
3. تلفت الدراسة إنتباه القائمين على إعداد وتطوير التعليم الجامعي إلـى الـى

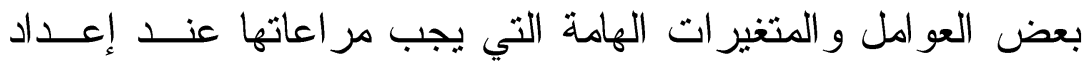
بر امج در اسية تلبي متطلبات العصر ونز اعي حاجات الثباب.

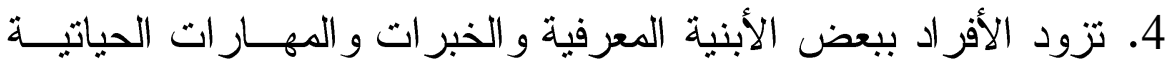

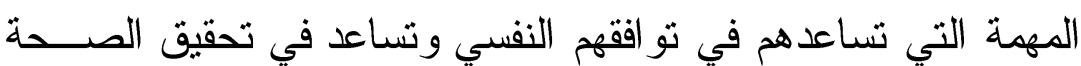

النفسية.

5. تسعى الدراسة للكثف عن أثز الإهتمام بجودة الحياة علـى أســاليب

مو اجهة الأفر اد للضغوط الحياتية.

6. تهتم الدر اسة بالمرحلة الجامعية التي تمثل مرحلة فارقة في حياة الأفر اد

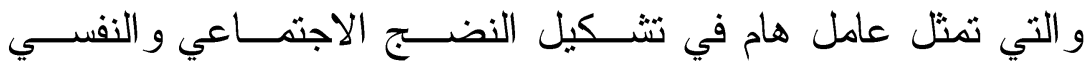

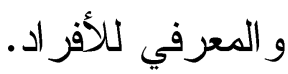

7. ندرة الدر اسات و البحوث التي اهتمت بإعداد بر امج لتحسين جودة الحياة بصفة عامة، وبر امج تحسين جودة حياة طلاب الجامعة بصفة خاصة. • أهداف الادر اسية: يمكن تلخيص أهداف الدراسة الحالية فيما يلي: 1. الكثف عن العلاقة بين جودة الحياة وأســاليب مو اجهــة أحسـداث الحيــاة الضاغطة.

2. تحديد أبعاد مفهوم جودة الحياة، وطرق تحسينه.

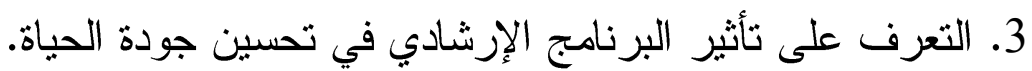
4. تحديد أساليب مو اجهة الضغوط السلبية و الإيجابية.

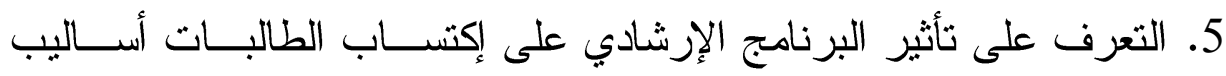
مو اجهة أحداث الحياة الضاغطة. 6. توجيه انتباه الباحثين إلى أهمية إعداد بر امج لتحسين جودة الحيــاة لــدى شر ائح مجتمعية مختلفة. 


\section{• مصططحات الار اسة:}

البرنامج الإرشادي: Counseling Program هو سلسلة من الإجراءات المنظمة و المتكاملة، الهادفة لتحسين جودة الحياة

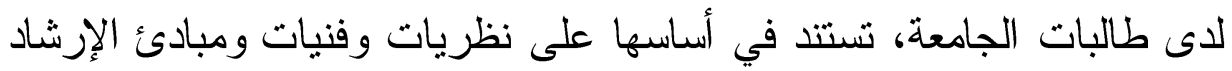

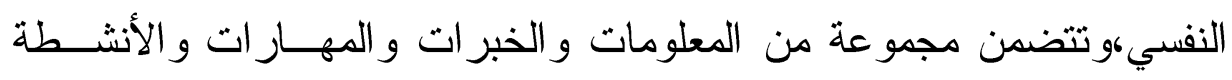
المختلفة التي تقدم للطالبات خلال فترة زمنية محددة من خلال مجمو عة جلسات

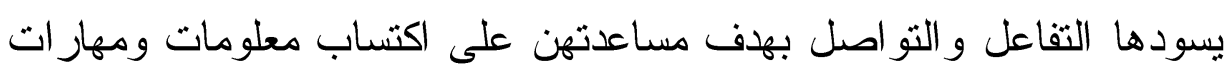
وسلوكيات جديدة تؤدي بهن إلى تحسن إدر اكهن لجودة الحياة، وتساعدهن على على على ألى مو اجهة أحداث الحياة الضاغطة. جودة الحياة: Quality Of life

هي التو ازن بين توقعات الفرد و أهدافه وحاجاته و الإشباعات الفعلية لها من

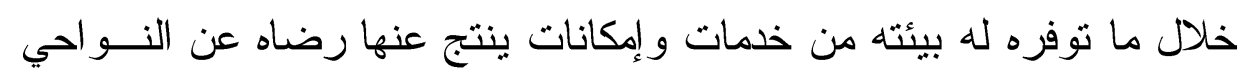

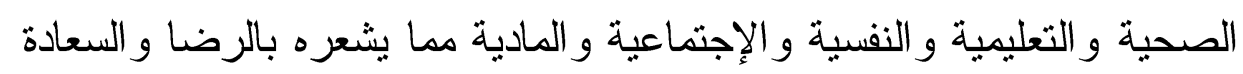

في إطار منظومته الثقافية و الدينية.

وتثضمن جودة الحياة الأبعاد الآتية:

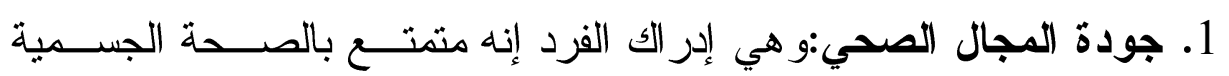

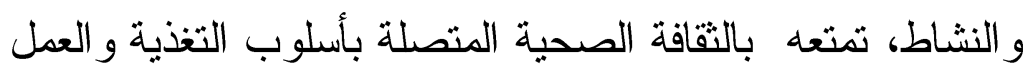

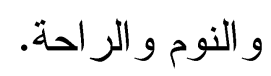

2. جودة المجال الإجتماعي: و هي إدر الك الفرد ونجاحه في تكوين علاقاتــهـ

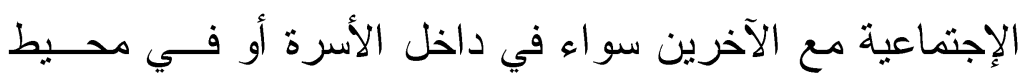

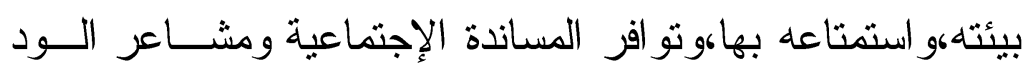
و الإحتر ام و التقة و الإنتماء. 
3. جودة المجال الإقتصادي: وهي إدراك الفرد ورضاه عن الناحية المالية دن

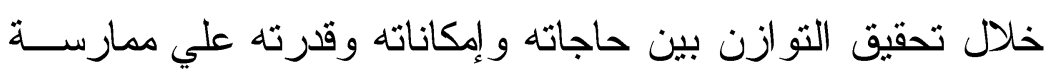
أنشطة و هو ايات وتمتعه بها.

4. جودة المجال النفسي: إدر الك الفرد لمفهوم ذات إيجابي و انخفاض شعوره

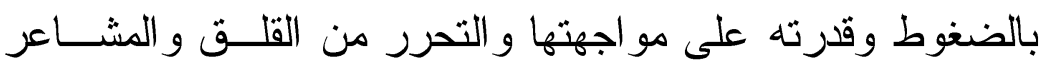

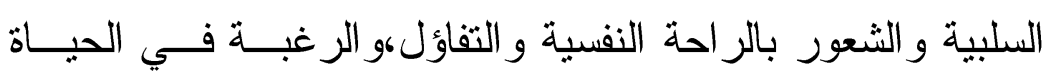
و إحساسه بمعنى الحياة و هدفه فيها و قدرته على التفكير .

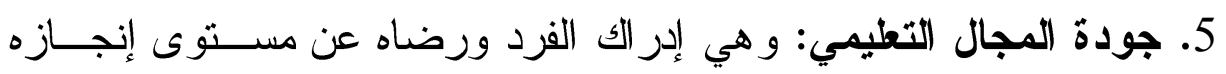

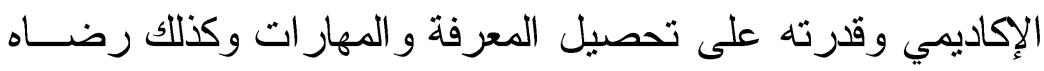
عن علاقاته بزملائه و أساتنته.

6. جودة مجال المعتقدات: و هي إدر الك لتمتعه وحريته في ممارسة معتقداتــــ الدينية و الثقافية و الحقوقية.

وتعد درجة جودة الحياة في الدراسة الحالية هي مجموع الدرجات التي تحصل وله عليها الطالبة على مقياس جودة الحياة المستخدم في الدراسة. أساليب مواجهة أحداث الحياة الضاغطة: Coping Styles Stressful life events هي مجموعة الخبرات المعرفية و السلوكية التي تساعد الفرد على إدراك وتقبل

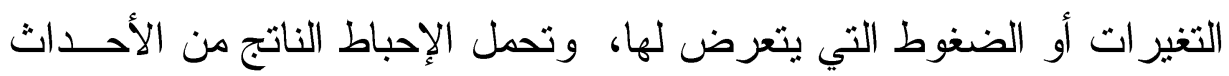

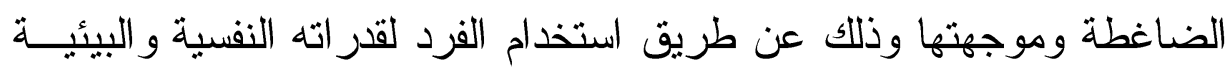
المتاحة، ليشعر الفرد بالتوازن و الراحة وتعد درجات أساليب مو اجهة أحسـداث

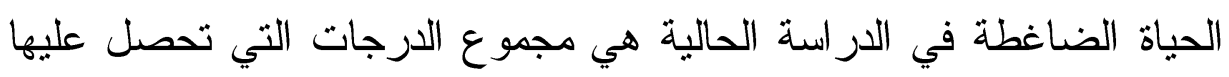
الطالبة على مقياس أحداث الحياة الضاغطة المستخدم في الدراسة. وتصنف أسلايب مواجهة الأحداث الضاغطة في الاراسة الحالية إلى خمســة أبعاد هي: 
(أ) الأساليب المعرفية: وتتمثل في التزكيز على حل المشكلة، و إعادة التقيـيم المعرفي للحدث الضاغط والبحث عن الإيجابيات بالموقف،و إدارة الذات، و إدارة الوقت، و استخدام مهار ات إتخاذ القرار .

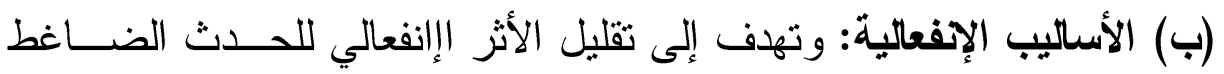

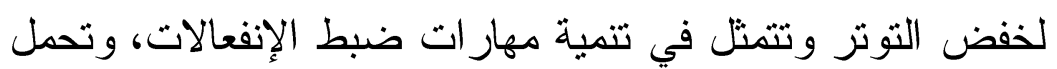

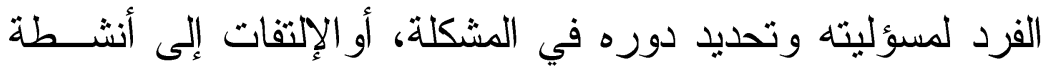

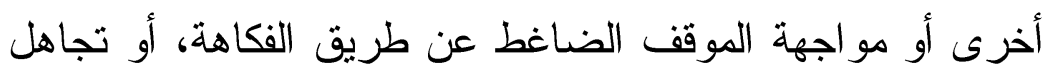
الضغط ، أو التقبل و الإستسلام.

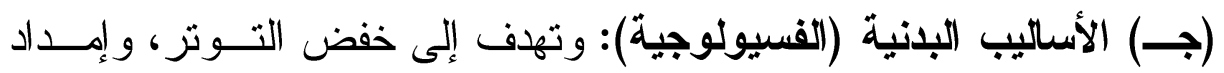

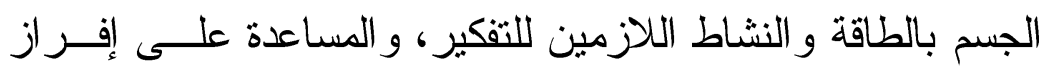

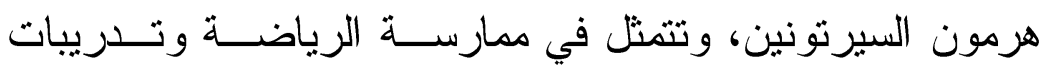
الإسترخاء،و إتباع أساليب تغذية سلمية.

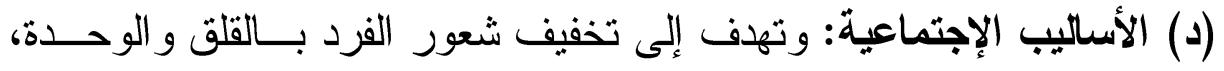
و إثعاره بالمساندة وتتمثل في التفاعل الإجتماعي مع شبكة علاقات إتهات

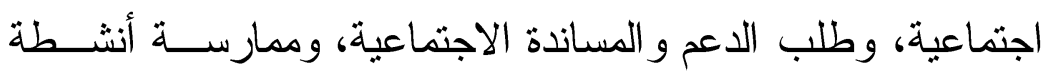

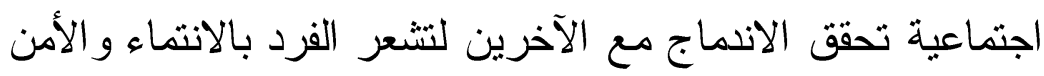

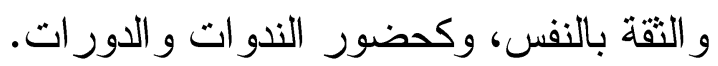

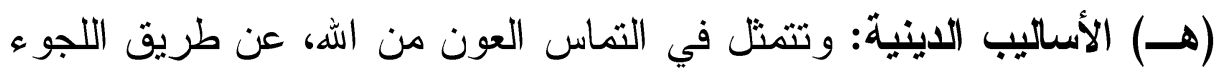

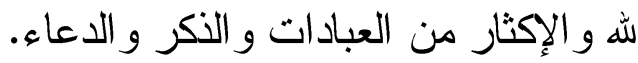
حدود الار اسةة: 1- عينه الدراسة: تكونت عينة الدر اسة من (25) طالبة من طالبــات كليــة

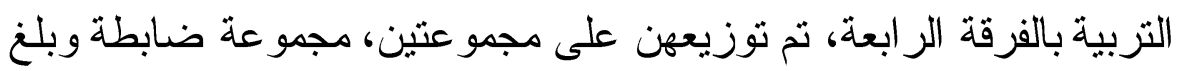
عددها (13) طالبة، ومجموعة تجريبية وبلغ عددها (12) طالبة . 
2- الحدود الزمنية: تم تطبيق الدراسة في الفصل الدراسي الثاني من العـام

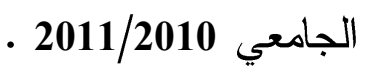

3- الحدود المكاتية: تم تطبيق الدراسة في كلية التربية بجامعة طيبة.

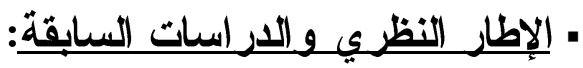

\section{المقدمة:}

أن مفهوم جودة الحياة يعد من الموضو عات المهمة فــي مجــالات كثيــرة

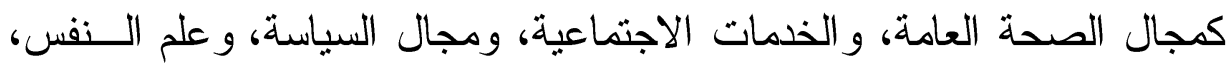

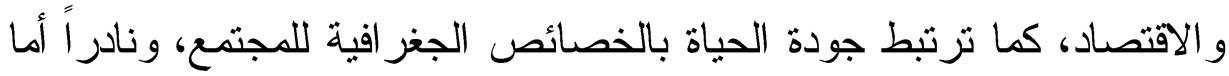

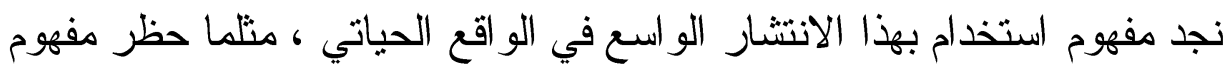
جودة الحياة .(حسام الدين عزب، (585:2004) وقد انتقل مفهوم جودة الحياة من العمومية إلى التخصصية، فقد انتقل مــن

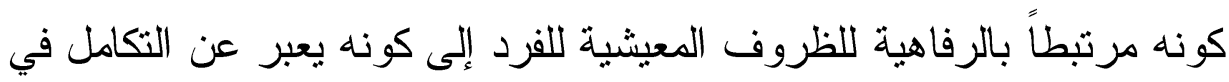

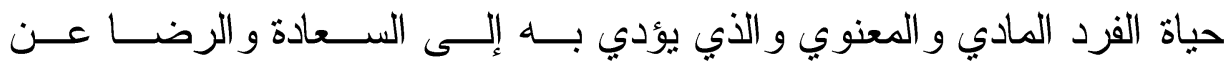

$$
\text { الحياة.(عصام فريد، 2008: 101) }
$$

ويشير شالوك Shalock (2004) إلى أنه على مدار العقدين الماضــيين تــ

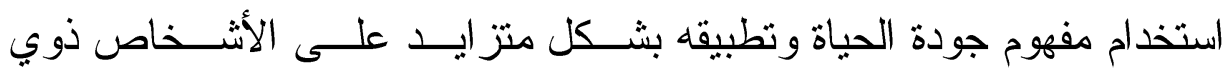

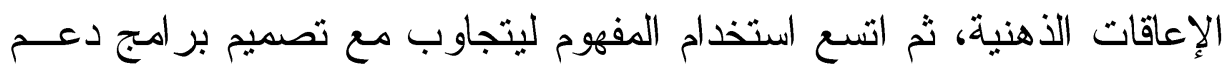

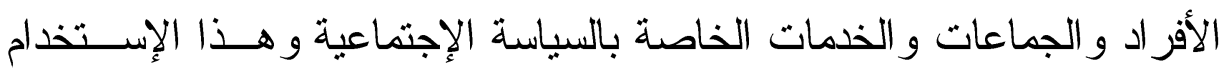
و الإهتمام نتيجة للنظرة الواسعة التي تري أن جودة الحياة هي نتيجة للإهنمام (Shalock,R.,2004:204). بالتعليم و الصحة وبر امج التأهيل وتري هويدا حنفي وفوزية الجمالي (2010) إن جودة الحياة لها أهمية بالغة

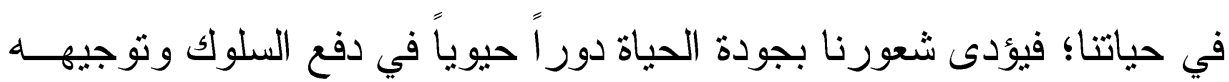

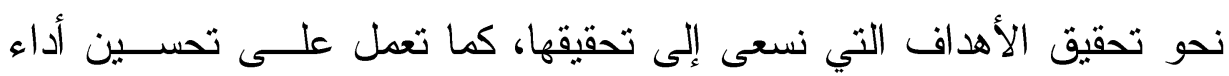
العمل، وتساعد الفرد على بذل الجها لمو اجهة الضغوط الهذى لهختلفة. 


\section{أولاً: مفهوم جودة الحياة:}

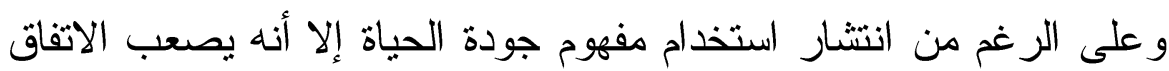

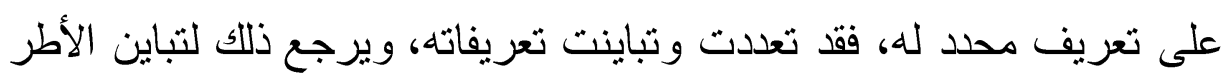

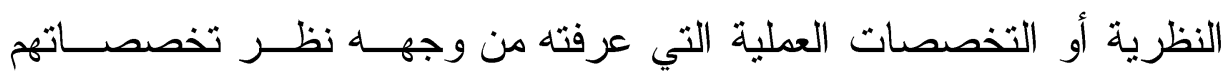
المختلفة.

ويرى عادل الأشول (2005) إن ذلك يرجع إلى لحداثة المفهوم على مســتوى

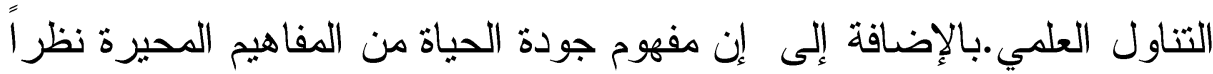

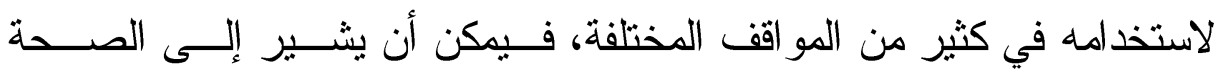

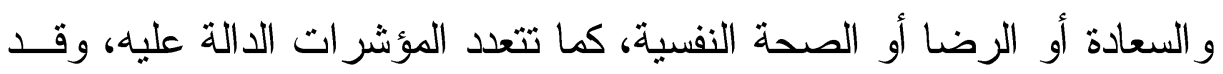
تبين أيضاً أن مفهوم جودة الحياة يتغير الزمن، وحالة الفرد النفسية و المرحلة

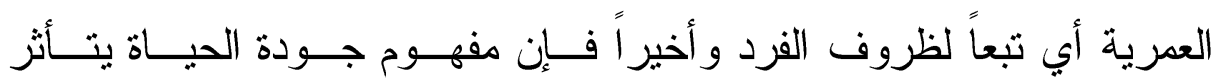
بالمتغير ات الثقافية لكل مجتمع وبالتالي قد يختلف التعريف من مجتمع لأخــر

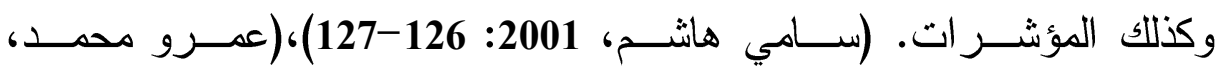

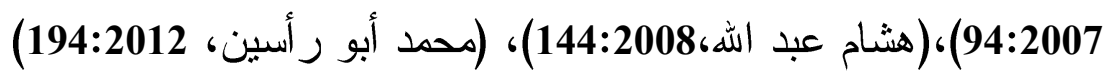
وفي ضوء ما سبق تعرض الباحثة بعض التعريفات لـفهـوم جـودة الحيــاة

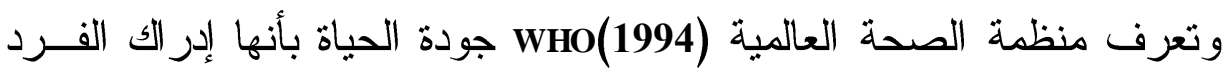

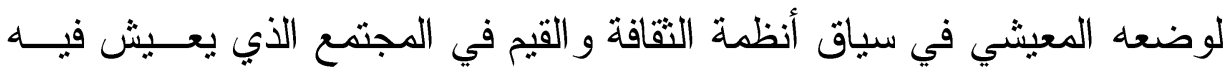

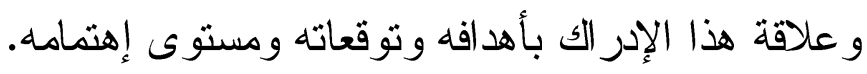

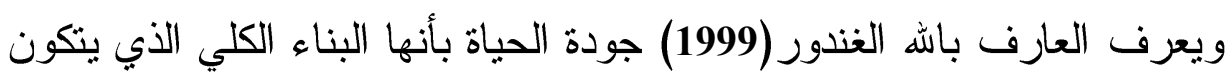
من مجموعة من المتغيرات التي تهدف إلى إثباع الحاجات الأساسية للإنسان بحيث يمكن قياس هذا الإثباع بمؤشرات موضو عية تقيس الإمكانات المتدفقة

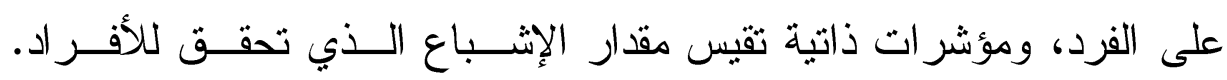
(العارف بالله الغندور، 27:1999) 
ويعرف حسن مصطفي(2005) جودة الحياة بأنها مجمو عة تقيمات الأفــر اد

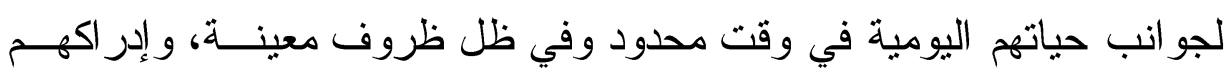

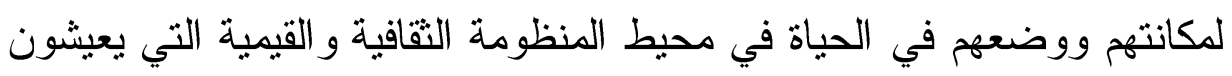

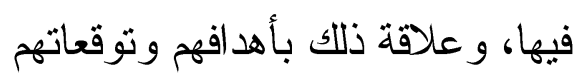
ومعايير هم و إهتماماتهم في ضو ء تقييمهم لجو انب حياتهم التي تحقق الرضا عن ونه

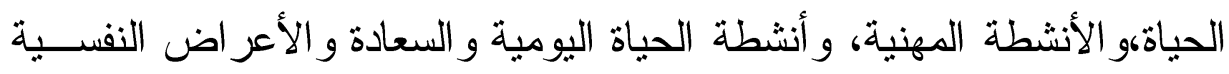

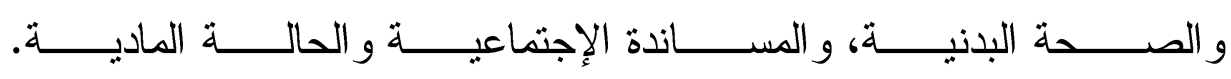
(حسن مصطفي، 15:2005) ويرى أنستيل و آخرون (2007) Anctil,et,al . إنه في

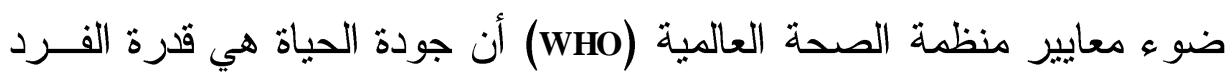

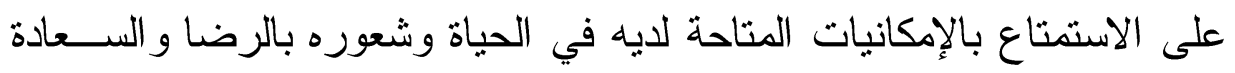
و الرفاهية، حتى ولو كان لديه ما يعوق ذلك.

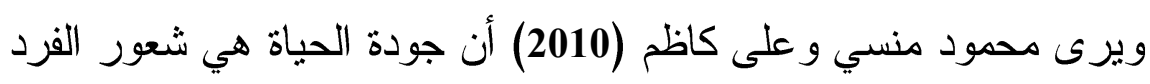

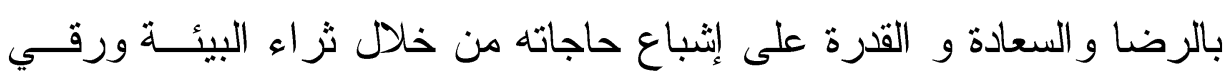
الخدمات التي تقدم له في المجالات الصحية و الاجتماعية و التعليمية و النفسـية ولية

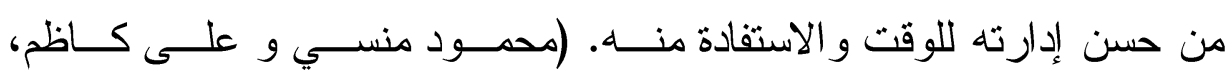
(45:2010

ومما يدلل على أهمية مفهوم جودة الحياة أن منظمة الصحة العالمية (SHO) اهتمت باه و عرفتها بأنها مفهوم يشير إلى تمتع الفرد بالصحة الجسمية و النفسية

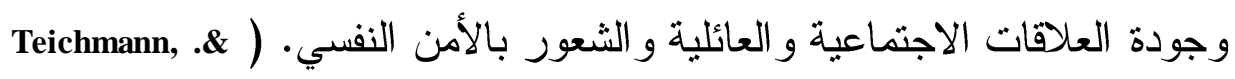
(et al.,2006:146 أما عصام عبد العزيز (2008) فقد عرف جودة الحياة بأنها مفهوم يعبر عن

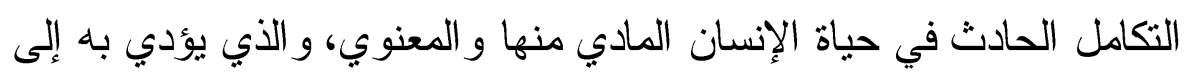
السعادة و الرضا عن الحياة. (عصام عبد العزيز، 101:2008) 
وترى زينب شقير (2010) أن جودة الحياة هي أن يعيش الفرد في حالـــة

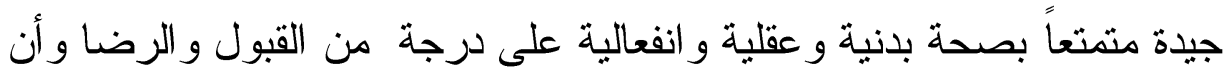

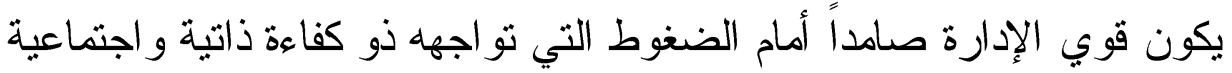

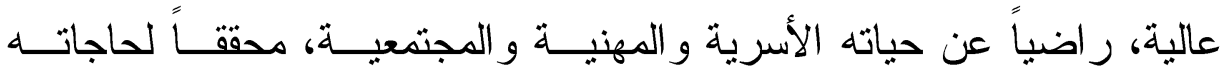

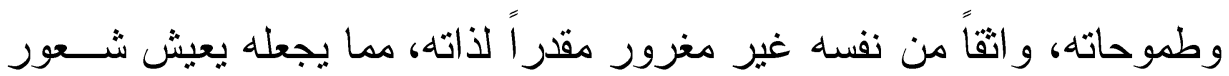

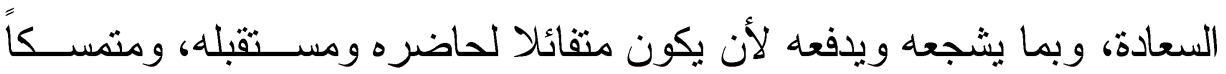

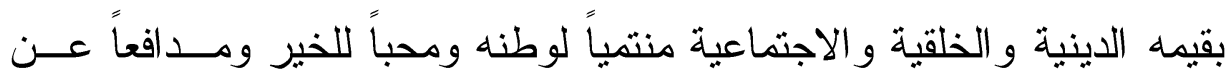

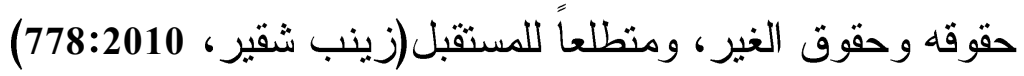

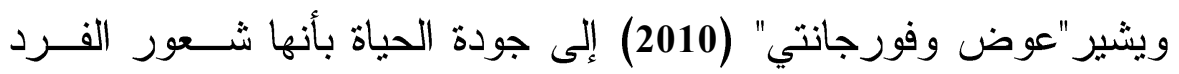

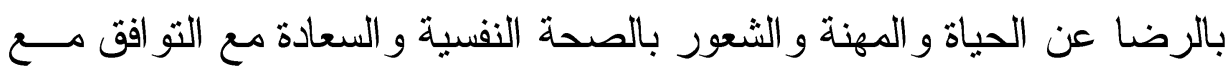
المجتمع. (Awad, Q. \& Voruganti, N., 2010:568) ويذكر وانج و آخرون أن جودة الحياة تعبر عن الرضا عن خمسة مجالات

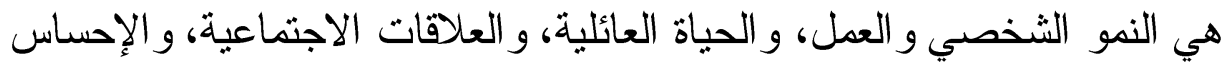
بالأمن. (Wang, J.\& et, al., 2010:32)

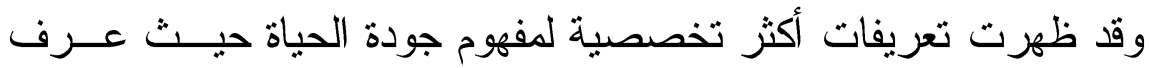

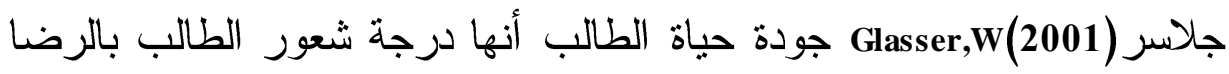

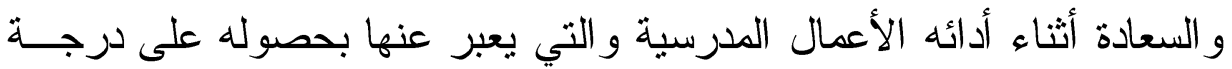
الكفاءة في التعلم، و أداء بعض الأعمال التي تتميز بالجودة وشعوره بالمسئولية

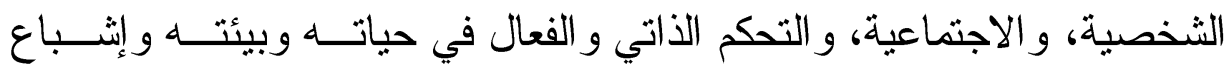
حاجاته النفسية بطرق فعالة ومسئولة وقدرته على حل مشكلاته مـــع ارتفــاع

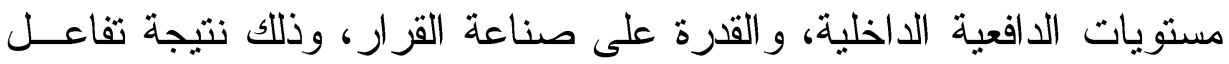

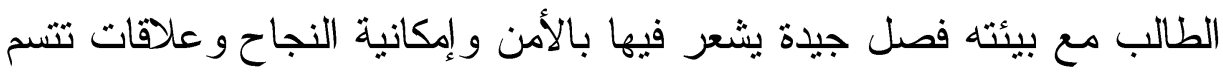
بالجودة.(Glasser, W., 2001:17) 
وفي ضوء ما سبق يتبين أن مفهوم جودة الحياة مفهومساً و اســاً يتــأثر

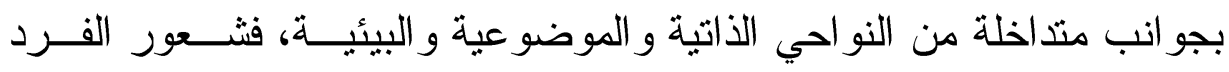

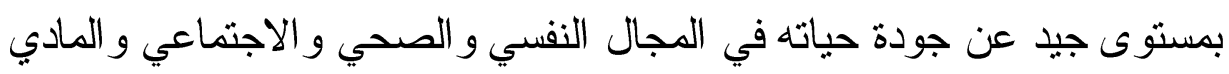

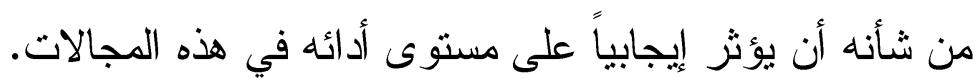

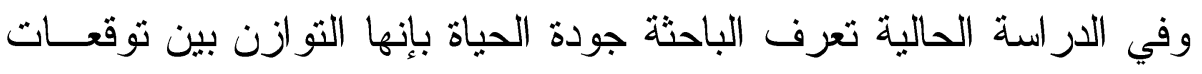

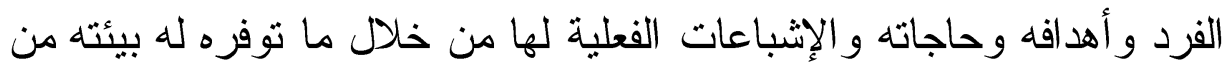

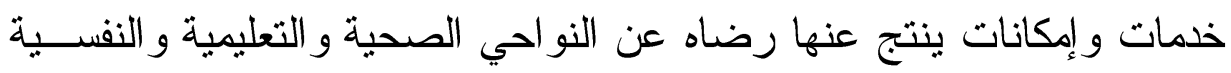
و الإجتماعية و المادية هما يشعره بالر احة و السعادة و الرضا من خلان رناه منظومته الثقافية و الدينية. • أبعاد جودة الحياة:

يشير جود (1994) Goode إلى أربعة عو امل أساسية تحدد جودة الحياة وهي •حاجات الفرد:وتتنتل على (الحب، التقبل، الجنس، الصداقة، الصحة، الأمان) • التوقعات بأن هذه الحاجات خاصة بالمجتمع الذي يعيش فيه الفرد. • المصادر المتاحة لإشباع هذه الحاجات بصورة مقبولة اجتماعياً.

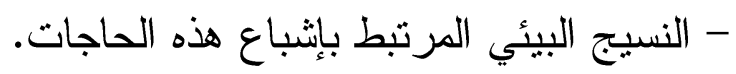
ويشير حسن مصطفي (2005)إلى أن أبعاد جودة الحياة التي يتمخض عنها

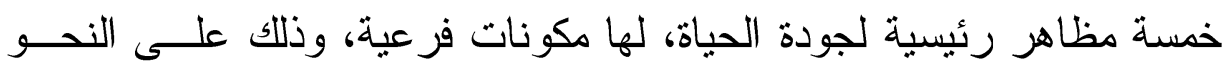
التالي: - أبعاد جودة الحياة وهي: - البي: -جودة الحياة الذاتية: وتعني كيف يشعر كل فرد باهية بالحياة الجيدة التي يعيشها أو مدى الرضا و القناعة عن الحياة و السعادة بها. -جودة الحياة الوجودية: وتعني مستوى عمق الحياة الجيدة داخل الفرد و التي وني

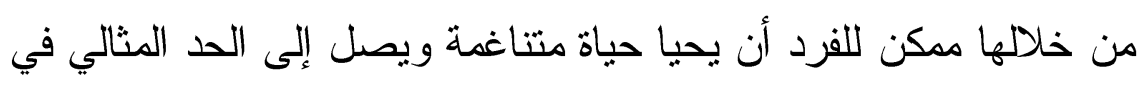


إثباع حاجاته البيولوجية و النفسية إلى ما يعيش في تو افق مع الأفكـار

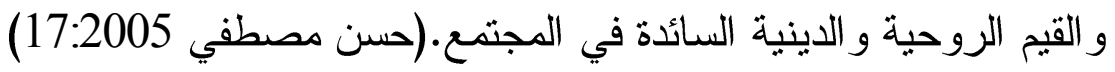

• مظاهر جودة الحبياة:

- العو امل المادية و التعبير عن حسن الحال - إثباع الحاجات و الرضا عن الحياة - إدر الك الفرد للقوى و المتضدنات الحية و إحساسه بمعني الحياة - الصحة و البناء البيولوجي و إحساس الفرد بالسعادة - جودة الحياة الوجودية ويقصد بها الوحدة الموضوعية و الذاتية لجو انب الحياة

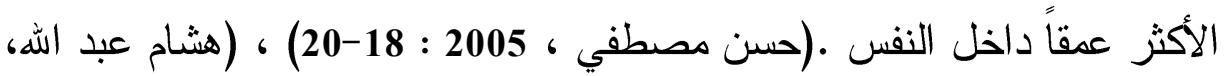
(محمد أبو رأسين، 2012 : 148: 2008 : 200 ويشير مورفي ومورفي (2006) Murphy \& Murphy إلى أن منظمة الصــحة العالمية أعدت مقياس لجودة الحياة عام (2006) حددت فيه معايير لجودة الحياة

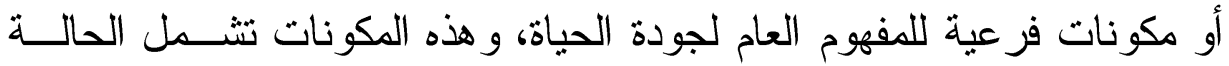
الجسمية،وتقدير وفعالية الذات، الاستقلالية، العلاقـــات الاجتماعيـــة إيجابيــة، الرضا عن الحياة و السعادة. وحدد محمود منسي وعلى كاظم (2006) أبعاد جودة الحياة لــدى طـلاب الجامعة في ستة أبعاد هي: وهئ

-جودة الحياة الأسرية و الاجتماعية - جودة العو اطف - جودة شغل الوقت و إدارته

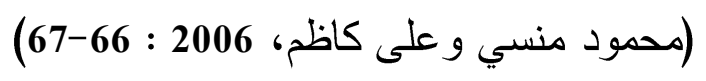

بينما يري شيك ولي Shek \& Lee أن جودة الحياة تتكون من مجــالين هما: * جودة الحياة الأسرية: وتثمل الجودة الو الديه، وجودة العلاقة مع الأبناء 35 
* جودة الحياة الإففعالية: وتشمل الرضا عن الحياة، وتقدير الذات و التفــاؤل

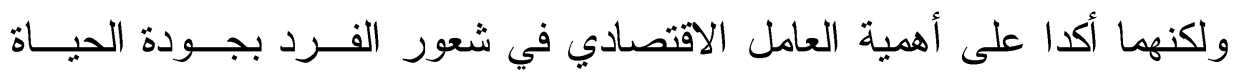

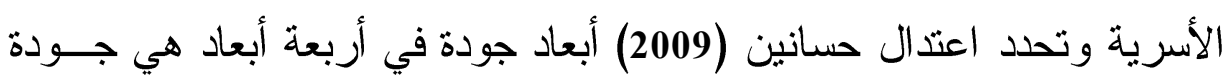

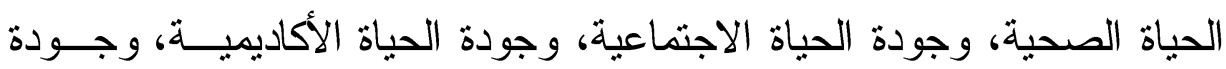
الحياة الإنفعالية. (اعتدال حسانين ، 2009: 246)

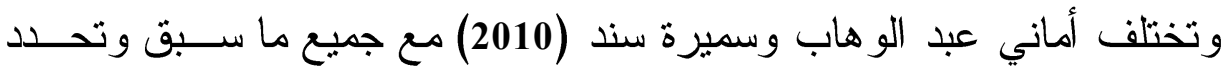

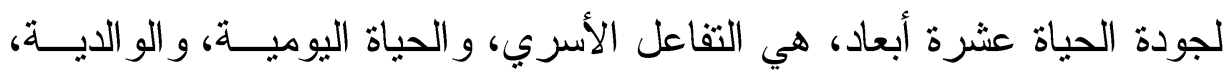

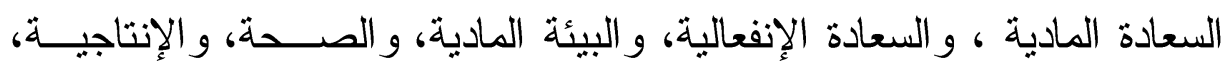
و السعادة الإجتماعية(أماني عبد الو هاب وسميرة سند، 2010 : 200 )

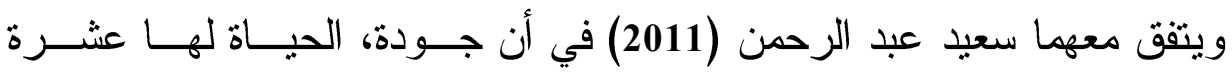

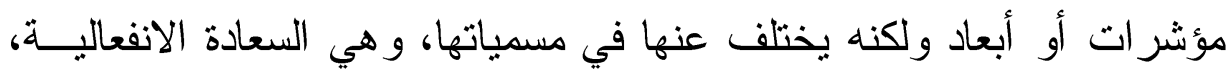

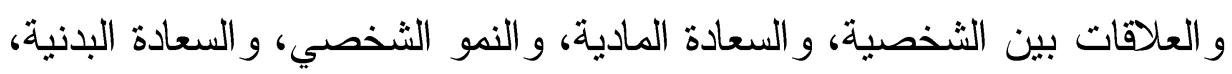

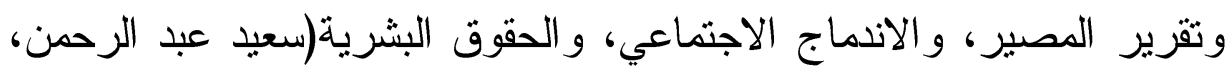
(233-232 : 2011 وقد أثنار سامي هاثم (2001) إلى أهمية البيئة المدرسية في تحديد جودة الحياة لاى التلاميذ وتحسينها من خلال ما تتيحه من:

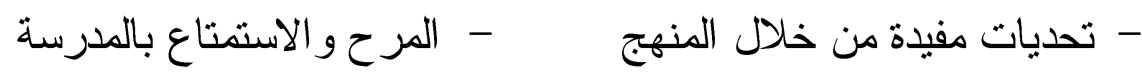
- الفرصة في تحقيق إنجاز ات إيجابية - إثباع الرغبة في حب الاستطلاع

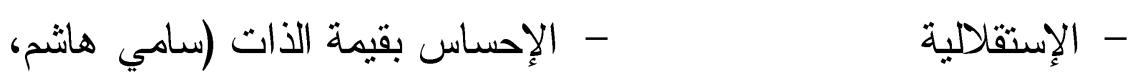
(141: 2001 ويقتر ح لو اساكي Lwasaki 2007 بعض العو امل التي تئدي إلى تحسين جودة

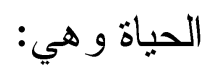
- المشاعر الايجابية المرتبطة بالتفاؤل و السعادة - التو اصل الاجتماعي و الثقافي 
- الهوية الايجابية وتقدير الذات - التعليم و التنمية الإنسانية - البحث عن معني للحياة ويري حمدي الفرماوي (1999)أن السبيل لجودة الحياة ورونقها يكـون فــي ثلاثة أمور هي:

- مجاهدة النفس: عن طريق استتهار الإر ادة، و الاستقامة، و السمو و العفة.

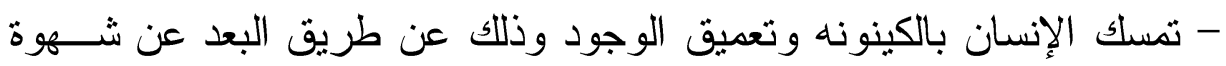
التملك، و البعد عن الأثره إلى الإيثار.

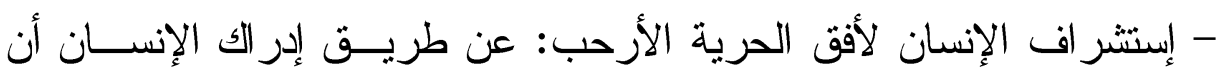

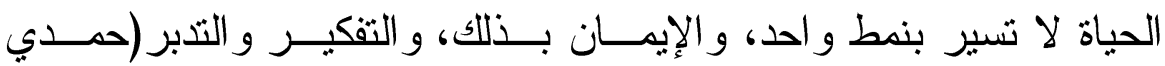

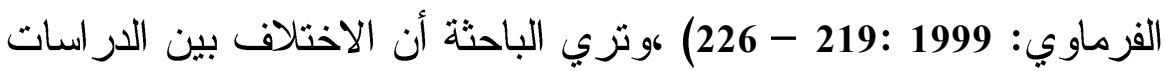

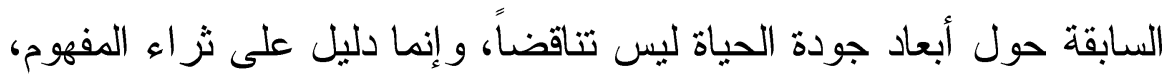
و التباين في عدد تلك الأبعاد يرجع إلى تفصيل البعض في بعض الأبعساد

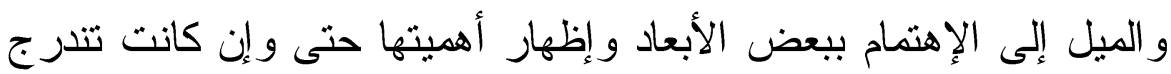

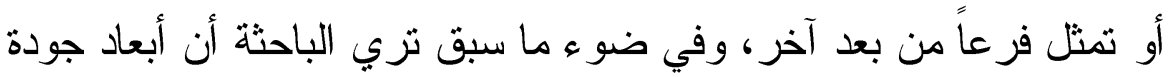

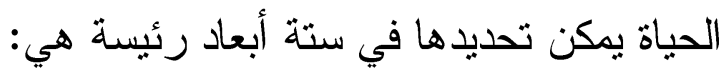
- جودة المجال الإجتماعي - مهي

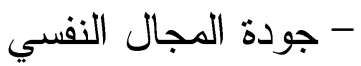

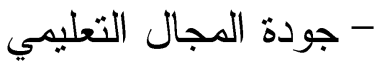

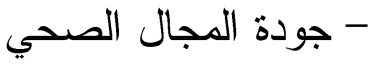

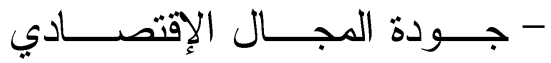

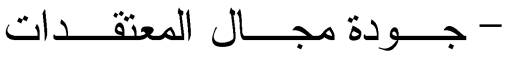
ففهوم جودة الحياة لدي الأفراد يرتبط ببعض العوامل الذاتية كفعالية الــذات الات لـات

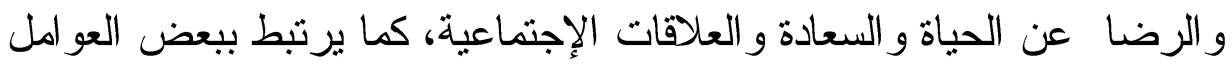
الموضو عية مثل الناحية الإقتصادية و البيئة و الخدمات الصحية. - النظريات المفسرة لجودة الحياة: (أ) نظرية الاختيار: - (أنطريات 
صاحب هذه النظرية هو جلاسر Glasser,W وتفترض النظرية أن الفرد يختار

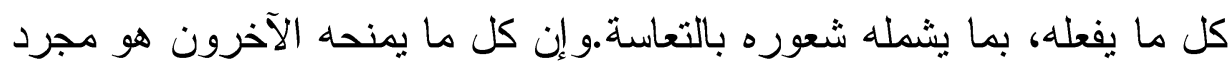

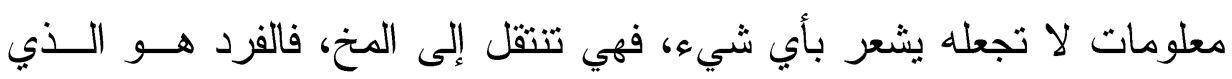

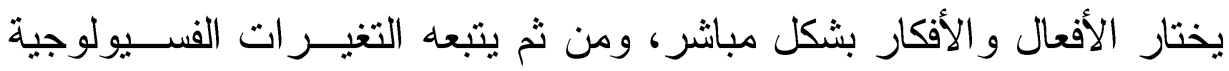
بالجسم، وكذلك الشعور (هانم مصطفي، 2009 : 158) وللنظرية عشرة محاور تقوم عليها وهي: بانئ

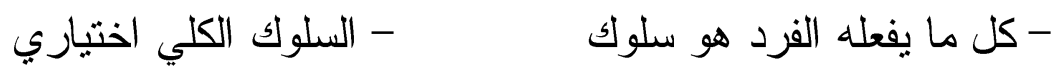
- السلوك الكلي يسمي باسم الجزء الأكبر من السلوك الذي يتعرف عليه

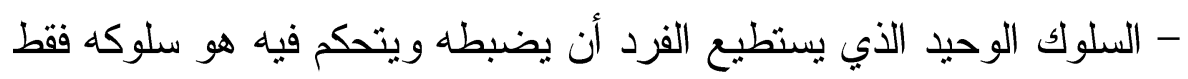

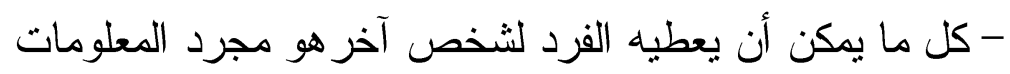

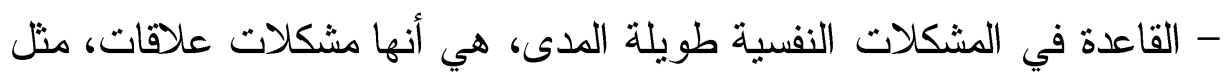
محاولة التحكم في الطرف الأخر بالعلاقة أو فقدان علاقات ذات ذات معني فـي الفي حياة الشخص محارله

- مشكلات العلاقات هي دائماً جزء من الحياة الحاضرة

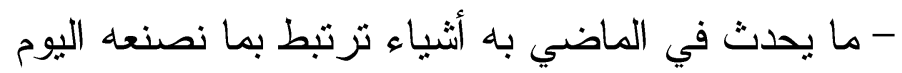

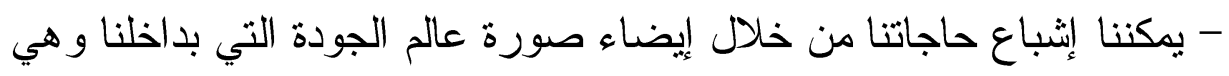
الصورة المتعلمة و المخزنة لدينا

- سلوك الفرد هو سلوك كلى يتكون من أربعة مكونات هي الفعل و التفكير

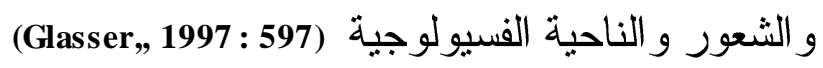
والأساسيات التي تقوم عليها النظرية هي:

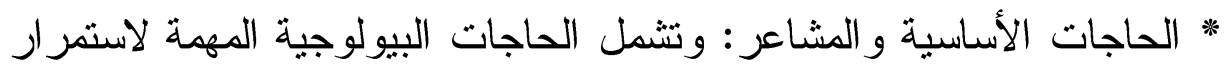

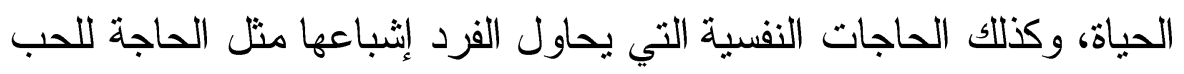

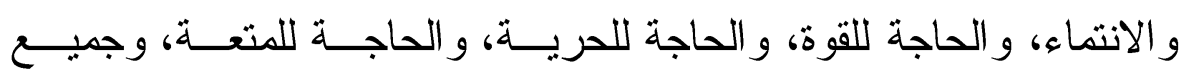

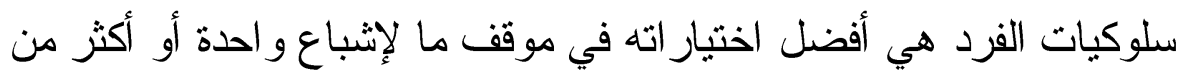


هذه الحاجات ويري جلاسر أن معرفة الفرد بهذه الحاجات هومـــا يعطيـــ القدرة على الاختيار السليم للسلوكيات التي تشبع هذه الحاجــات وتثــــره بالسعادة. (Glasser, W., 1998 : 15 ) أما عالم الجودة عند "جلاسر" فيري أن سبب اخــتلاف الأثــخاص فــي

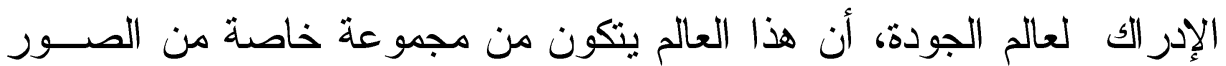
التي تعد أفضل الطرق لإشباع واحدة أو أكثر من الحاجات الأساسية. و هذه الصور تصنف في ثلاث فئات هي:

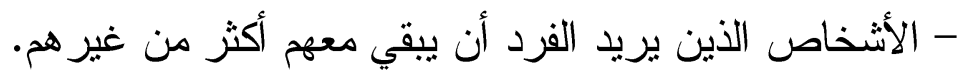

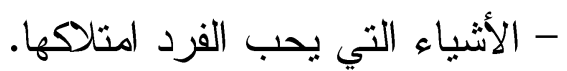
- الأفكار التي يعتقد الفرد فيها و التي تحكم جميع سلوكياته. ففي أي وقت يشعر فيه الفرد بالجودة يكون ذلك بسبب اختياره لســلوكيات

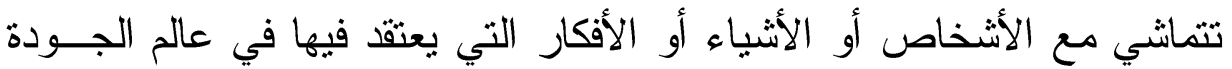

$$
\text { الخاص باه(هانم مصطفي، } 2009 \text { : } 162 \text { - 163) }
$$

كما يري جلاسر أن جميع سلوكيات الأفراد مختارة، وأن السلوك يتكون مسن

$$
\text { - أربع مكونات هي: }
$$

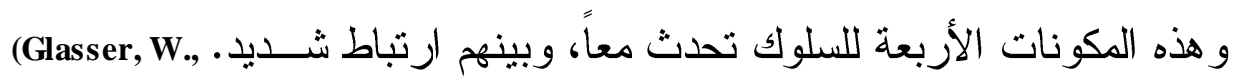

\section{(ب) النظرية التكاملية:}

Ventegodt, Merrick صاحب هذه النظرية هو فينتل جودت وميريك وانرسون

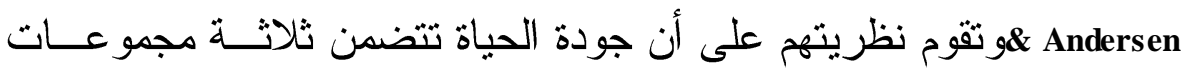
منفصلة على متصل يبدأ من الذاتية إلى الموضو عية، وتشمل جودة الحيــاة

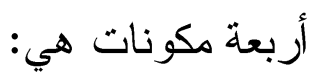




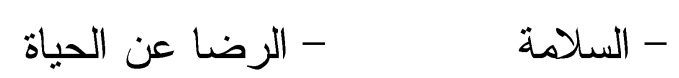

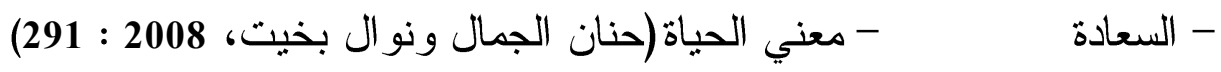
وكل مجموعة تهتم ببعد من أبعاد الجودة، وهي كما يلي:

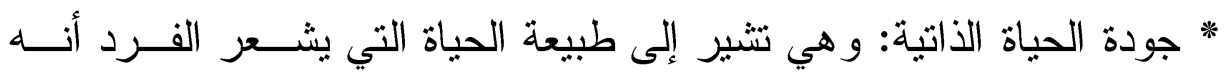
يحياها، إذ أن درجة رضا الفرد وسعادته بالحياة هي انعكاس لرؤيته الذاتية، لهئه

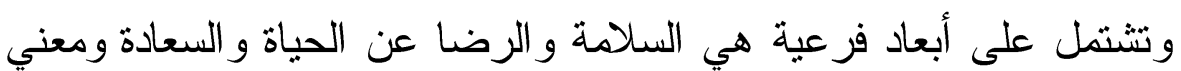

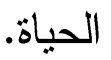

* جودة الحياة الوجودية: وتعني كيفية الحياة الجيدة على المستوى العميق، من

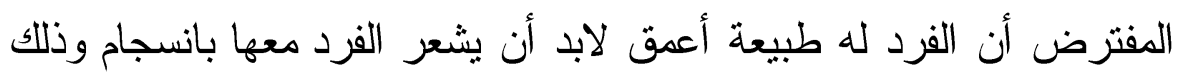

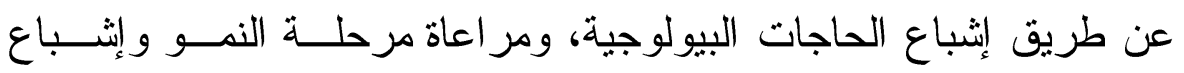
الجو انب الروحية و الدينية.

* جودة الحياة الموضوعية: و هي تهتم بالظروف الخارجية، ويقصد بها إدرالك الفرد للعالم الخارجي، و هذا الإدر الك يتأثز بالثقافة التي يحيا فيها الفرد.

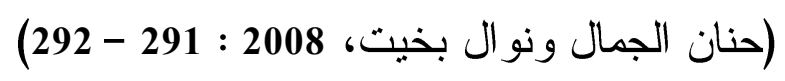

(Ventegodt, S. \& etal., 2003 - 1035 - 1040)

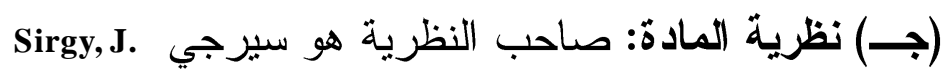

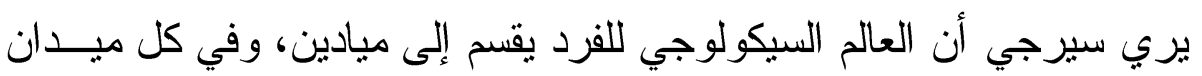

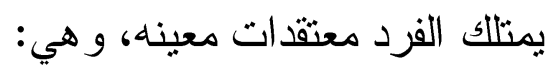
- للأفر اد اعتقادات عن أنفسه تتكون في عقو لهم في ميادين كالصحة و المهنة و العائلة و المجتمع ومستوى الحياة. - للأفر اد معتقدات عن القيم تخص مستوي العيش حسب الممتلكات و الدخل

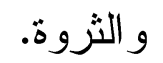

- رضا الفرد عن الحياة يستمر من مستوي الاخل و الثروة، وهذا يؤثر فـي

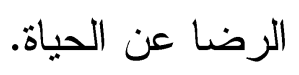


و الإختلاف البسيط بين الصورة، الذاتية التي يكونها الفرد نتيجة لتقيمة لنفســه

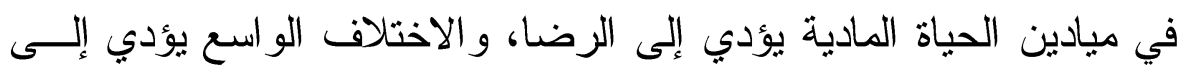
عدم الرضا..Sirgy, M. etal., 1995 : 259) ويري " فينيجودت و آخرون" (Ventegodt, et. AL (2008) أن العو امل المهمة لجودة

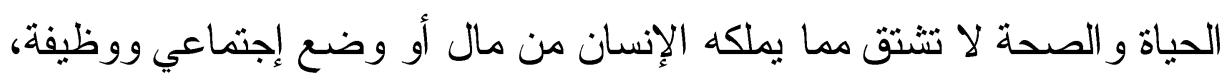

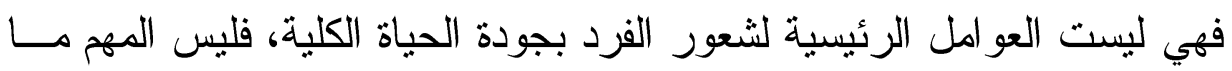
يملكه الفرد، و إنما كيف يري ويقيم ويتعايش مع ما يملكه .

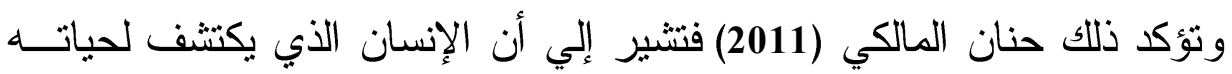

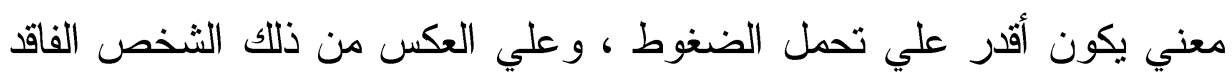

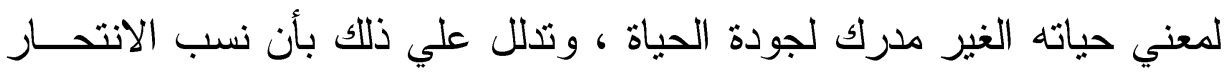

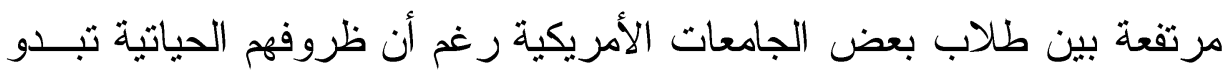

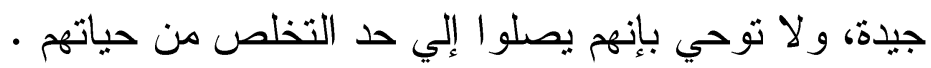
ولقد وجهت بعض الدراسات الحديثة ومنها در اسة مويني و آخــرون (2008)؛

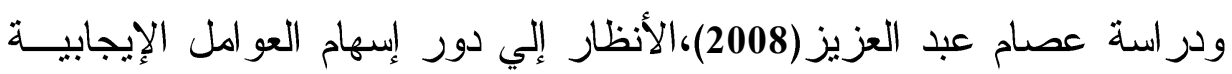

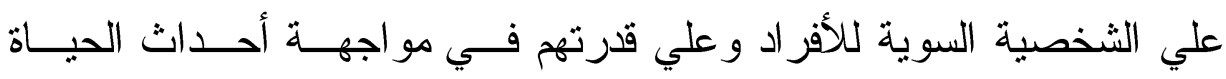

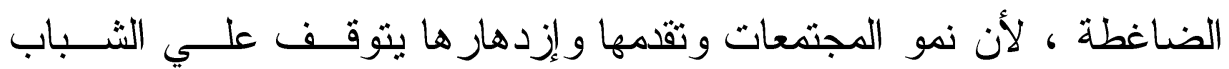

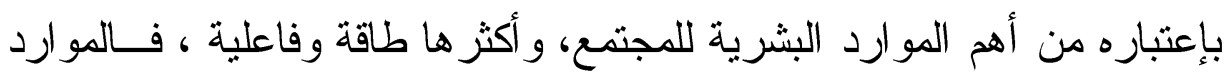

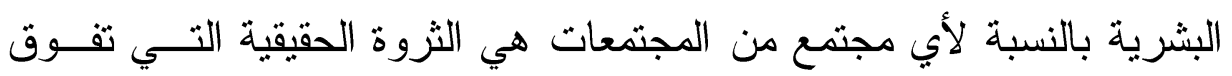

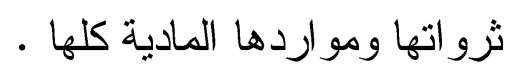

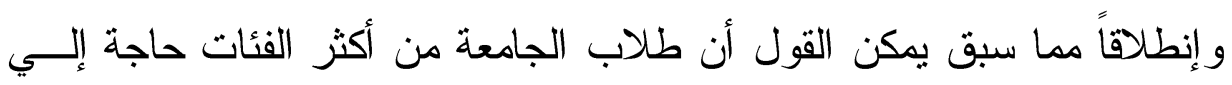

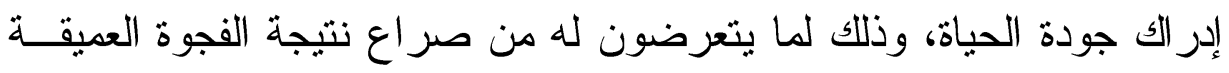
بين الثقام المادي و التكنولوجي الذي يسير بخطي سريعة لا يقابلها في مستوي

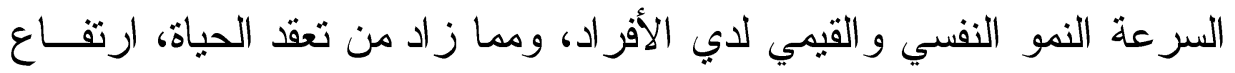
سقف طموحات الثباب مما زاد من إحساسهم بوطأة الضغوط، مما أدي إلـي لـي لفي 
ظهور العديد من الإضطر ابات النفسية و السلوكية، وزاد مــن المعانــاة لــدي

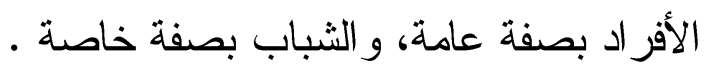

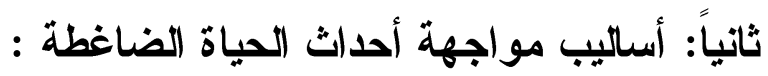

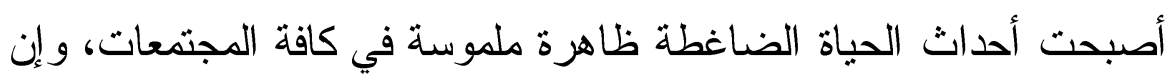

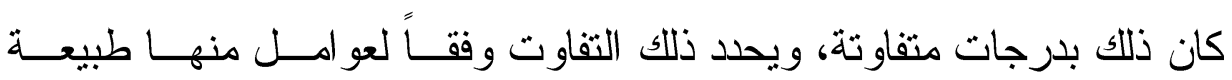

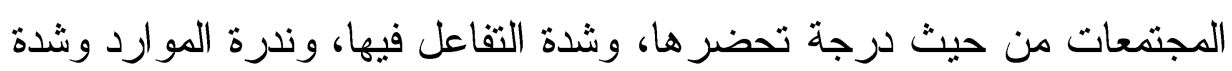

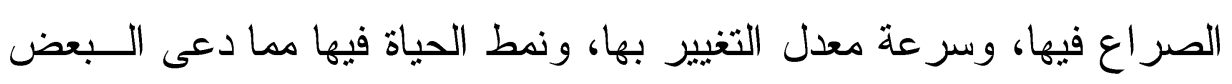
لتسمية هذا العصر بعصر الضغوط النفسية.(أمير بخش، 2007: 16)

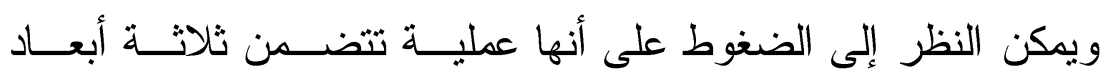

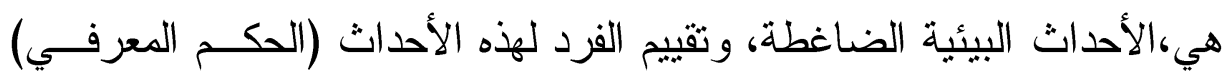

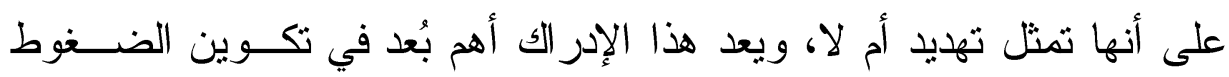

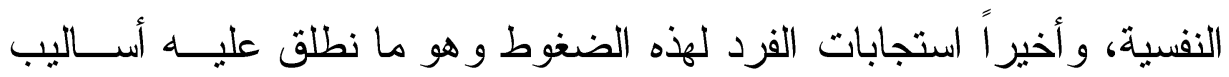
مو اجهة أحداث الحياة الضاغطة.(سامي عبد القوى، 2002، 328) وتتحول أحداث الحياة إلي ضاغطة، عندما تستمر تلك الأحداث ولا يستطيع

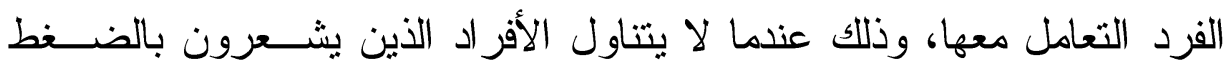
النفسي للتصف سلوكهم بالجمود، أو عندما تتر اكم هذه الضغوط و لا يتعـاملون

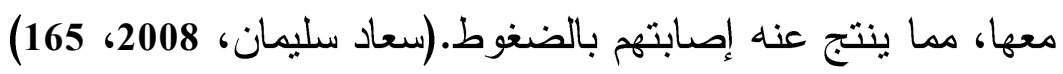

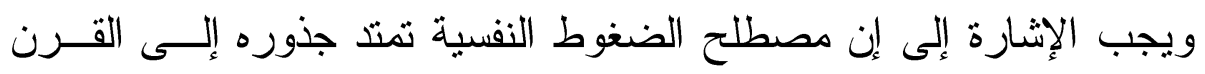

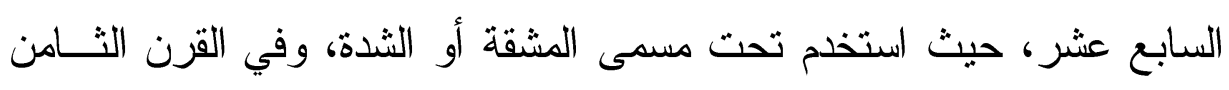
عشر استخدم بمعنى الإجهاد.(وحيد مصطفى كامل، 2005: 575) ويعد "هانزسيلي" Selye أول من قدم مصطلح الضغط النفسي و عرفه بأنـــه

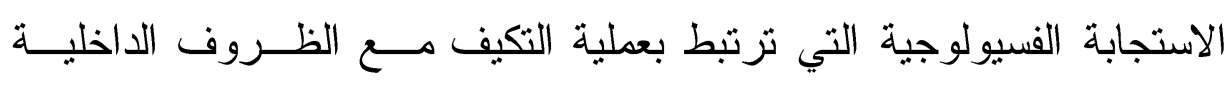

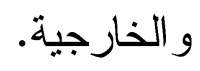


ويعرف سار افينو Sarafino (1994) الضغوط بأنها الحالة الناتجة عن إدر الك

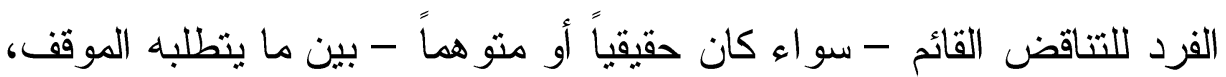

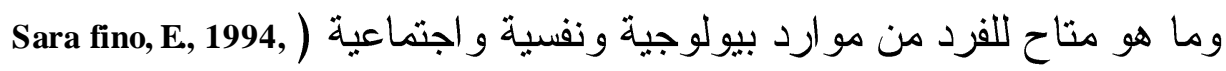

بينما يعرفها أحمد عبد الخالق (1998) بأنها هي المواقف العصيبة للحيــاة

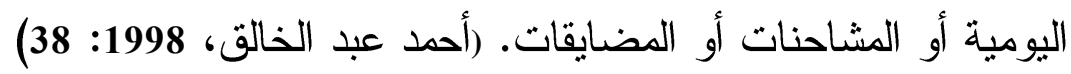

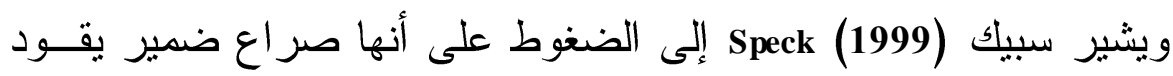

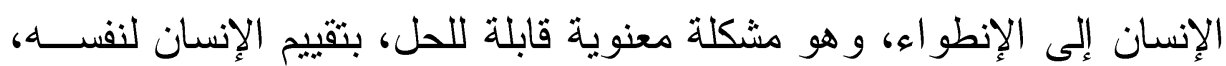

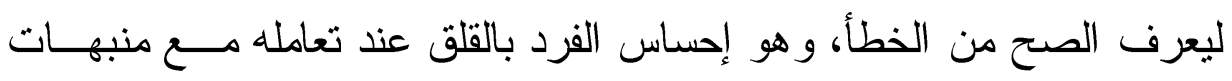

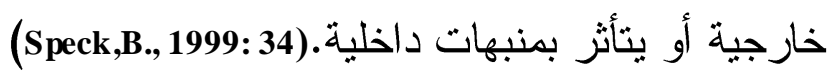
وتذكر هالة عبد الرحيم (2001) أنه يمكن تعرف الضغوط على على أنها مجمو عة

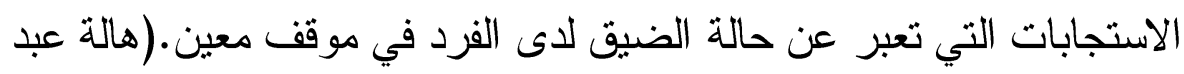
الرحيم، 2001: (19)

ويرى عبد الله السهلي (2010) إن الضغوط هي تفاعل بين الثخص وبيئته

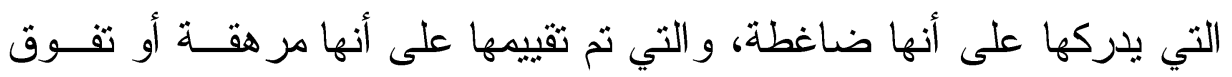
مو ارده للتغلب عليها وتعرض حياته للخطر .(عبد الله السهلي، 2010: 17)

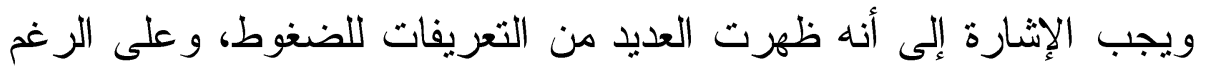

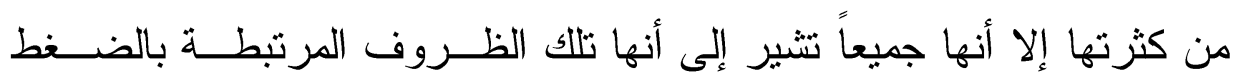

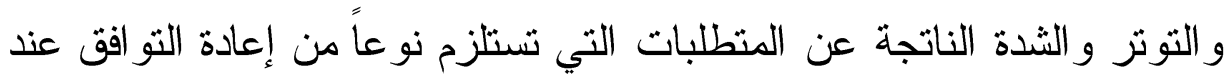

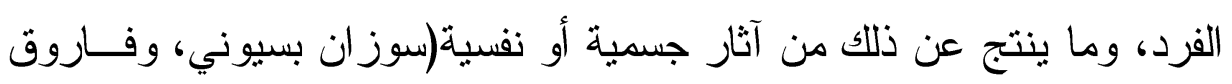

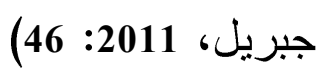
وقد اهتم علماء النفس بأحداث الحياة كدخل لدر اسة الضغوط النفسية التي تتعكس على الحالة الجسمية و النفسية للفرد، فالضغوط ترنبط بأحداث الحيــاة

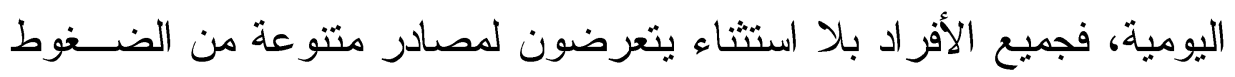




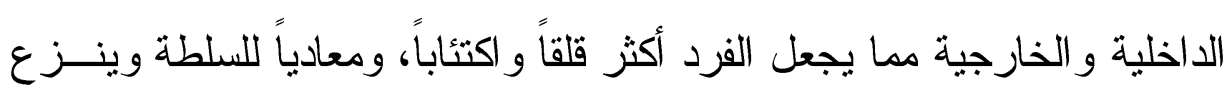
إلى العزلة كإجراء وقائي يحميه من الأحداث الضاغطة. (عماد عبد الــرازق، 2006

وتعرف زينب شقير (2002) أحداث الحياة الضاغطة بأنها مجموعة مـنـ

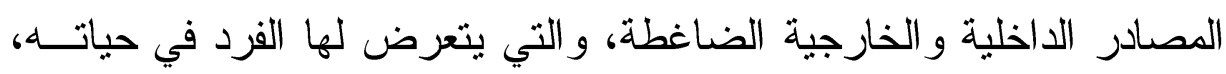

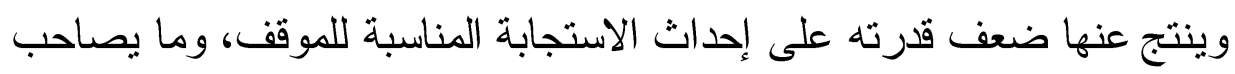

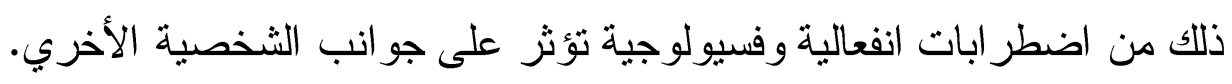

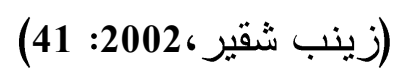

وتثير إيمان محمود (2010) إلى الأحداث الضاغطة على أنهــا الأحسـداث

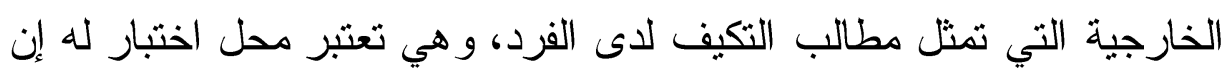

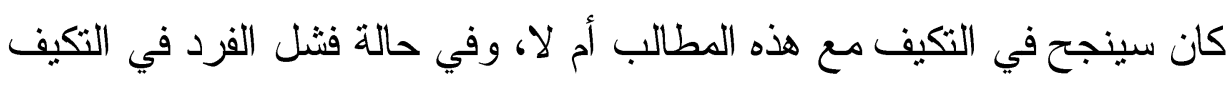

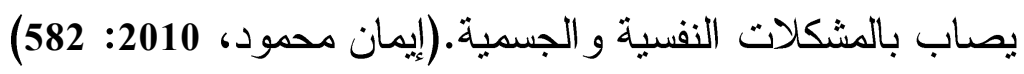

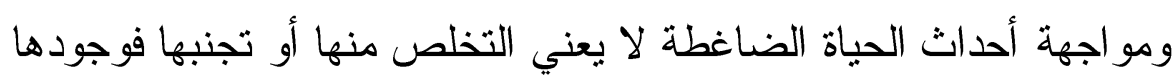

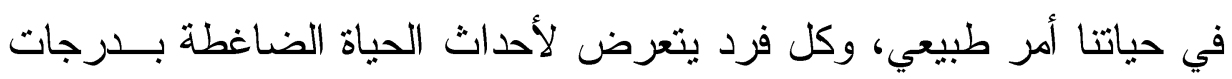

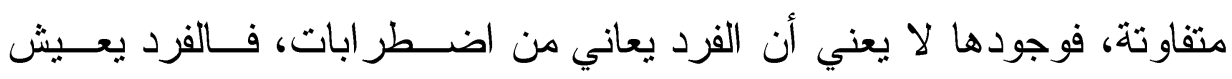

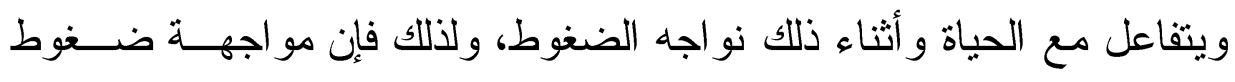

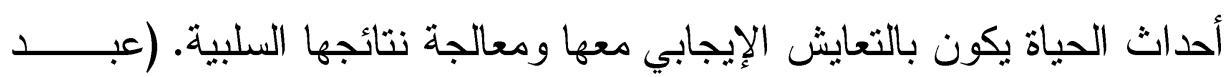
الستار إبر اهيم، 1998: 224)

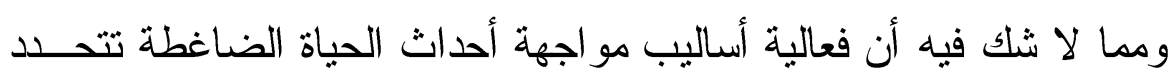

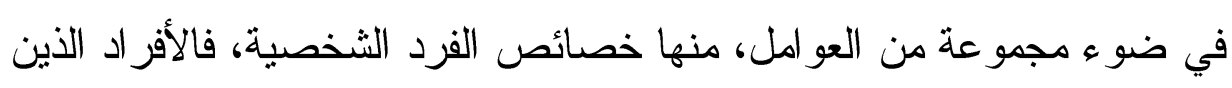

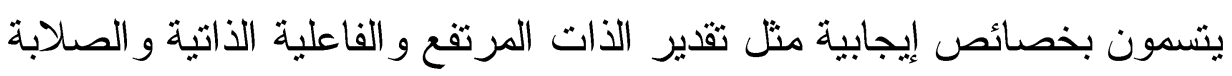

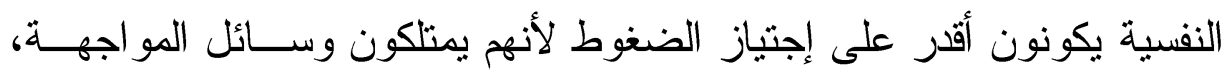

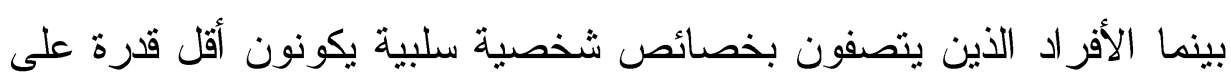

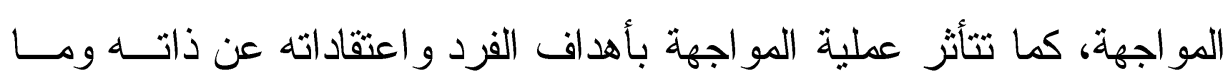


يحيط به، كما أن للفروق الفردية دوراً في إختلاف تقييم الأفراد للأحداث على

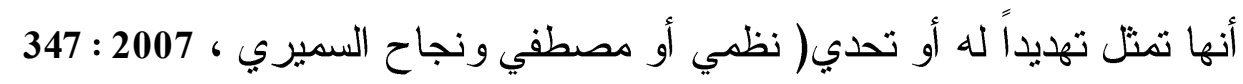

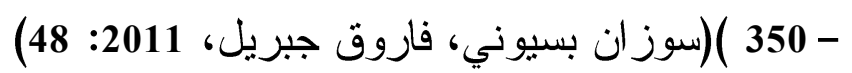

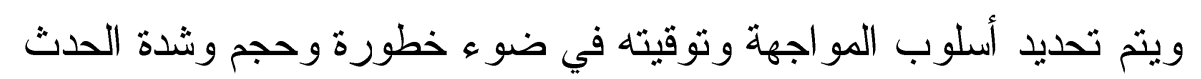

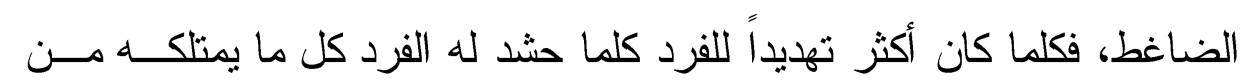
طاقات المو اجهة بفاعلية بعكس إن كان قليل الخطورة، فيميل الفرد إلى تأجيل

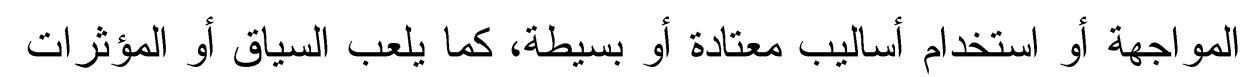

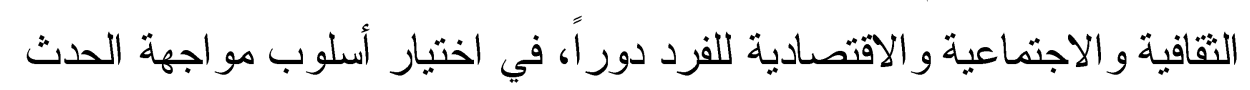
الضاغط، ففي الثقافة الشرقية كثيراً ما يتم ثقبل الحدث الضاغط و الاستســام للقدر أكثر من الثقافة الغربية(محمد السيد عبد الرحمن، 2004: $176-178$ 1 ويعرف "ليتمان" Litman أساليب التعامل مع المو اقف الضاغطة بأنها

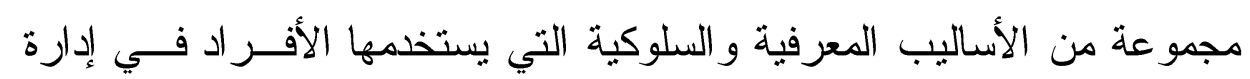

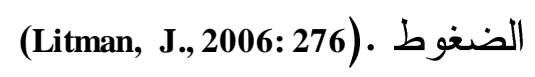

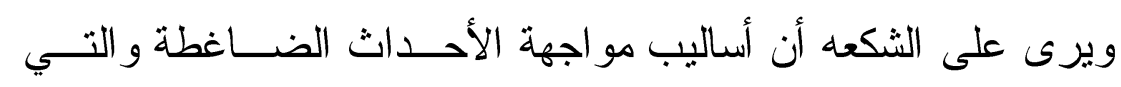

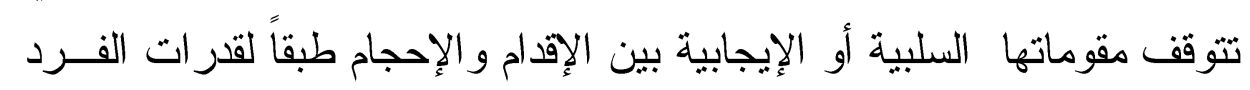

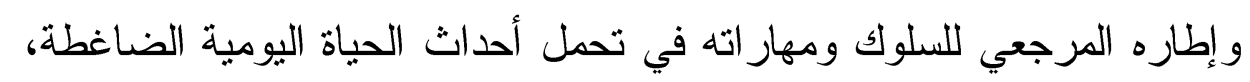

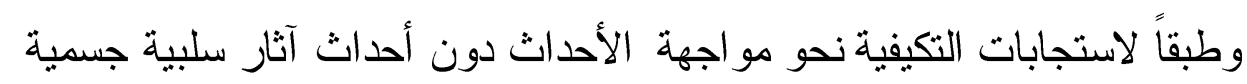

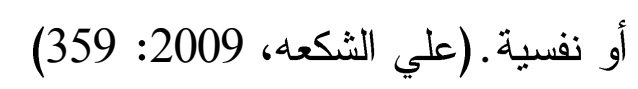
وتوضح حكيمة آيت (2012) أن أساليب مو اجهة الأحداث الضاغطة هـي لهي مجموعة من المجهودات المعرفية أو السلوكية التي يوظفها الفرد بهدف التعامل مع الأحداث الضاغطة، وذلك لتقليص وضبط وتحمل ما تسببه تلك الأحــداث

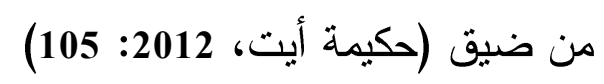

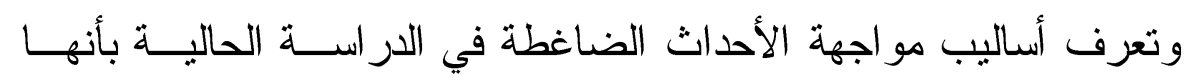

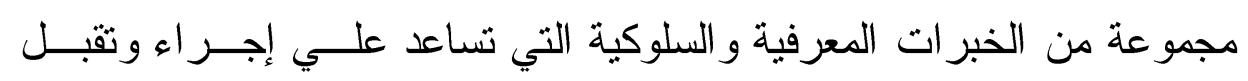
45 
التغيرات التي يتعرض لها الفرد ، وتحمل الإحبــاط النـاتج مــن الأحـــاث الضاغطة ومو اجهتها، وذلك عن طريق استخدام الفرد لقدر اته النفسية و البيئية

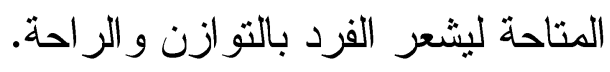
ـ خصائص الأحداث الضاغطة:

1. أن الحدث الضاغط هو تغير يسبب الضيق أو عدم الارتياح للفرد.

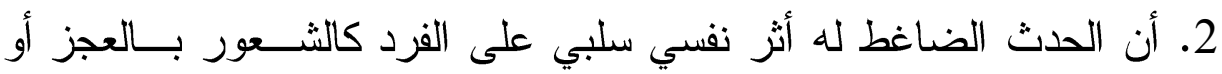
التوتز أو الخوف أو الإحباط.

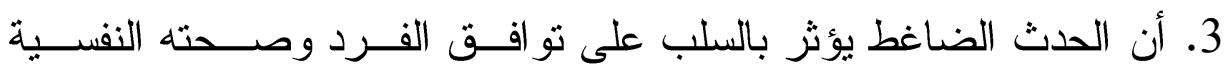
و الجسمية.

4. أن تأثير الحدث الضاغط قد يكون ظاهر أو خفي على الفرد وكــللك قــــ يكون مباشر أو غيرمباشر و أيضاً قد يكون تأثيره حالي أو بعيد المدى، ويتوقف كل ذلك علــى شــدة

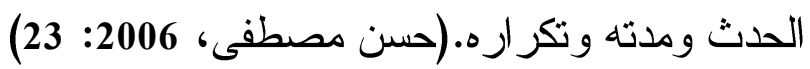
• أنواع أحداث الحياة الضاغطة: ويقسم عمرو محمد(2007) مصادر الضغوط في أحداث الحياة وهي أربعة.

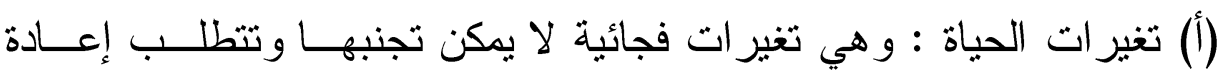
التكيف.

(ب) الكوارث: و هي ضغوط لا يمكن التنبؤ بها أو التحكم فيها مثل الحروب.

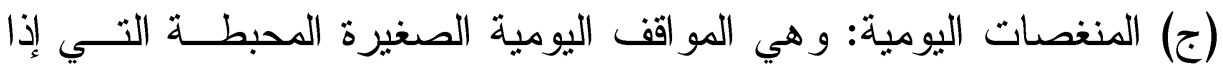
تجمعت تؤدي إلى ضغط أثند تأثير أ من غير ها.

(د) الضو اغط الإجتماعية: و هي ضغوط يعاني منها المجتمع مثل تدني

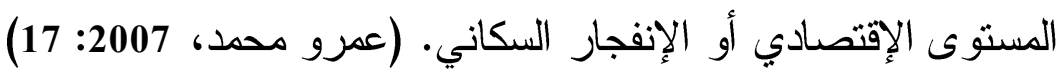
و تقسيم ماكنمار ا MacNamare (2000) الضغوط التي تو اجه الثباب في ثلاثة 
1. الضغوط المعيارية: وتتنتل على الضغوط المتصلة بالحاجات الأساسـية مثل التغير ات الجسمية و الدر اسة و العلاقات الإجنماعية. 2. الضغوط الغير معيارية: وتشنتل على حالات الفقد مثل الوفاة أو الطلاق أو الأن

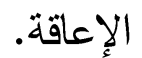
3. الضغوط اليومية و المو اقف المزعجة التي يو اجهها الفرد و لا تستمر لفتـرة (MC Namare,S.,2000: 8). طويلة ويذكر طلعت أحمد (2008) تقسيم آخر للضغوط تبعاً لمدة تأثير ها إلى هـ ضغوط مؤقتة و هي التي تؤُز على الفرد لفترة وجيزة ثم تزول، وهي عـادة

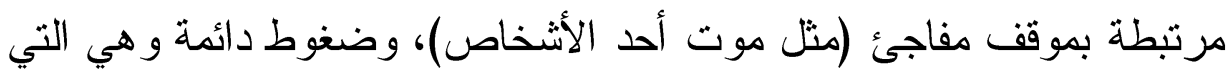

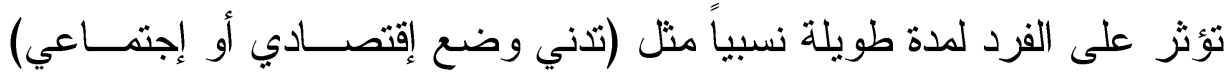

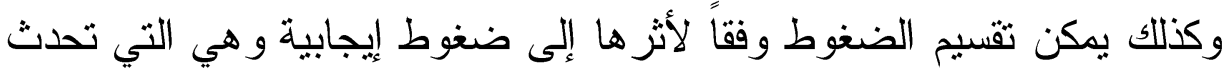

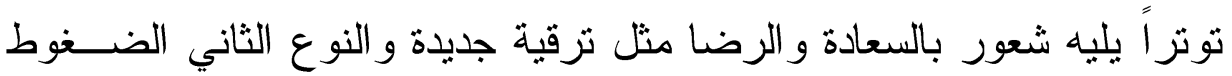

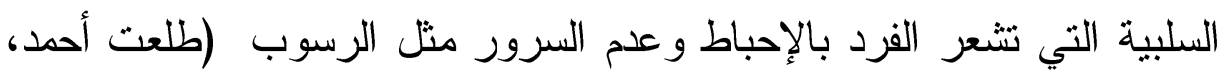
(65:2008

- مصادر الضغوط: - مصن ويمكن أن نوضح أهم مصادر الأحداث الضاغط في ثمانية مجالات و هي: (أ) مشكلات إنفعالية: كالثورة و الغضب انتب. (ب) مشكلات إقتصادية: تدني المسنوى الاقتصادي.

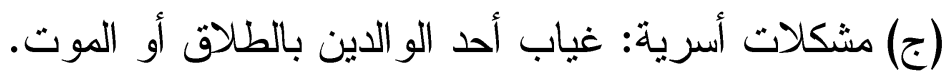

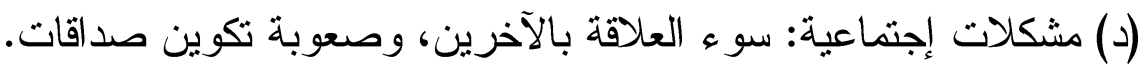
(هـ) مشكلات نفسية: كإنخفاض تقدير الذات، و إنخفاض مستوى الطموح. (ز) مشكلات شخصية: كجمود الر أي، و التردد، و المقاومة.

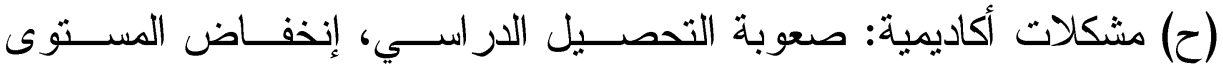
الار اسي، الرسوب.(محد الصافي، 2010: 639) 
ويلخص خالد العبدلي (2012) مصادر الضغوط المتنوعة في مصدرين اثتـين هما:

1- الإحباط: وهو إعاقة الوصول إلى هدف ما، وتنشأ من العقبات التي تعطل

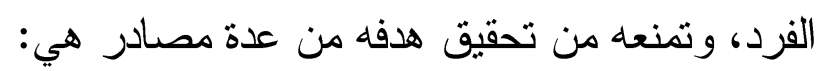

$$
\begin{aligned}
& \text { - الظروف الصحية }
\end{aligned}
$$

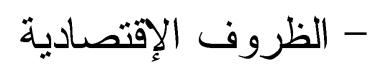

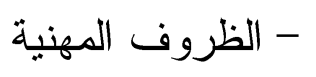

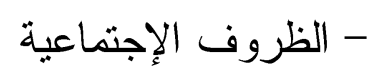

$$
\begin{aligned}
& \text { - العلاقة بين الأشخاص }
\end{aligned}
$$

2- الصر اع: وهو الرغبة في تحقيق أو الحصول على هدفين مختلفين في نفس الأنس

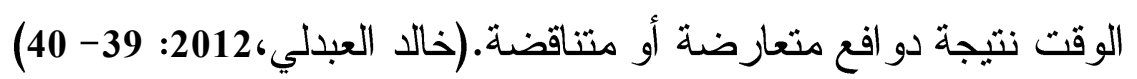

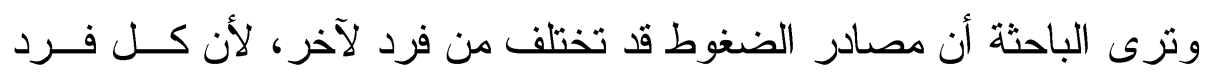

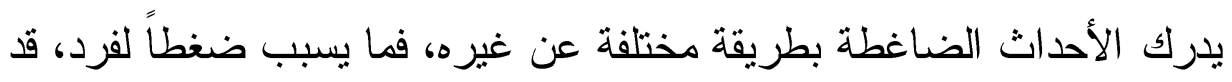

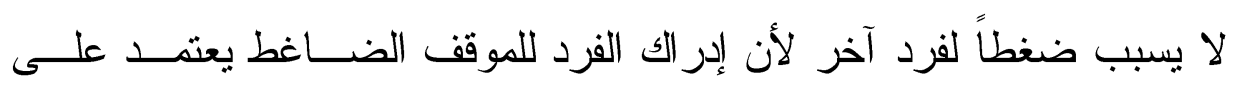

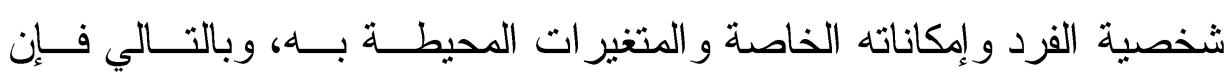
الأحداث الضاغطة تتشأ من مصدرين، المصدر الأول : هو المصدر الداخلي

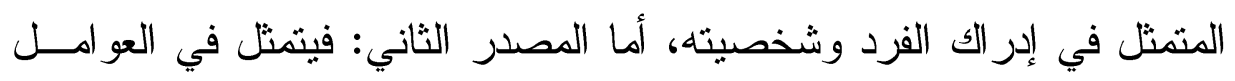
البيئية المحيطية به سو اء كانت اقتصادية أو إجنماعية أو بيئية أو طبيعية.

\section{- أساليب التعامل مع الضغوط:}

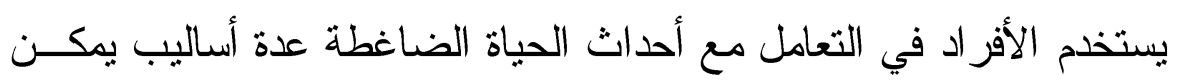

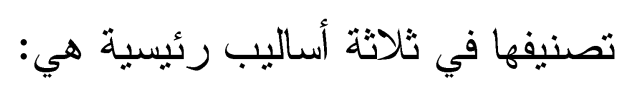

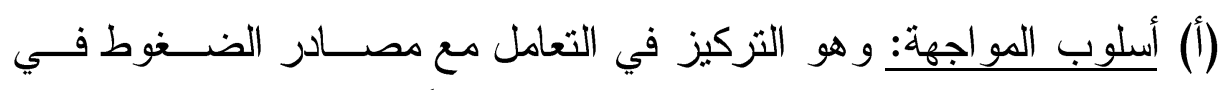

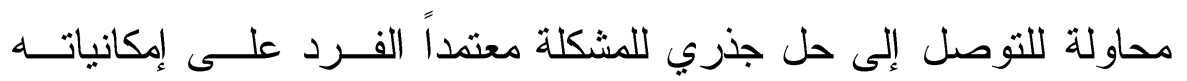
وقدر اته. - مجاه 
(ب) إلتماس العون: يركز على السعي لطلب المساندة الآلهية، وكذلك المساندة

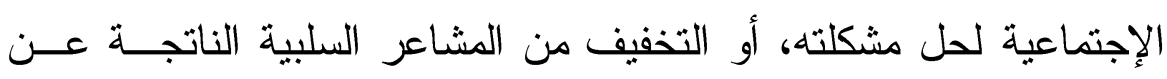
الضغوط.

(ج) أساليب سلبية: وهي تستخدم في المو اقف التي يدركها الفرد على أنهــا. تفوق إمكاناته و أنه عاجز على مو اجهتها بنفسه أو بالإعتماد على الآخرين،

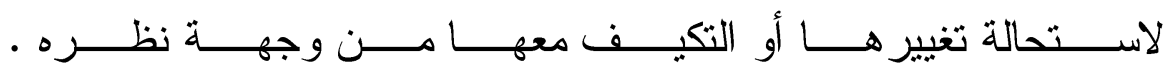
(عبد المنعم حسيب، 2007:164) ويوضح كل من سعيد عبد الرحمن (2011)، وحكيمسـة آيـــ (2012) أساليب المو اجهة، فيصنفاها في أسلوبين رئيسيين هما: 1- أساليب المواجهة المركزة على المشكلة : وتتضدن أسلوبين فرعيين هما:

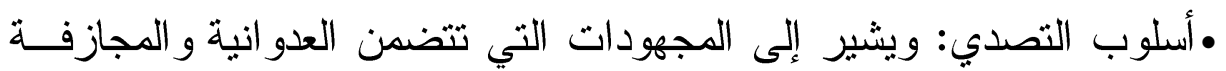
للتخلص من الحدث الضغط.

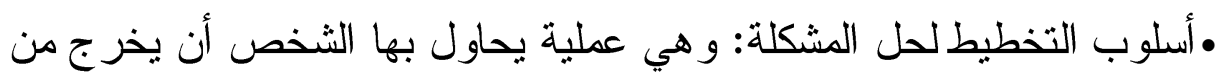
الموقف الضاغط باستخدام أسلوب حل المشكلات. 2- أسلايب المواجهة المركزة على الإنفعال:

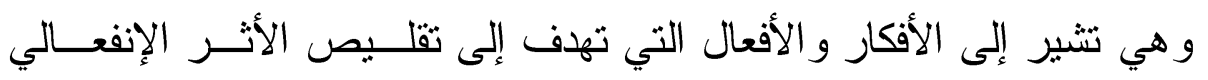

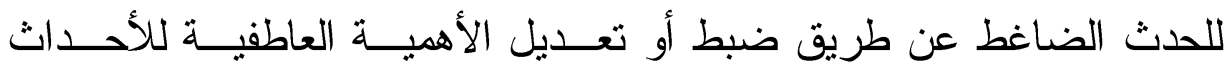

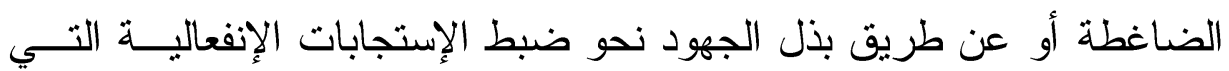

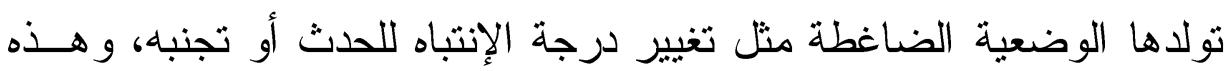

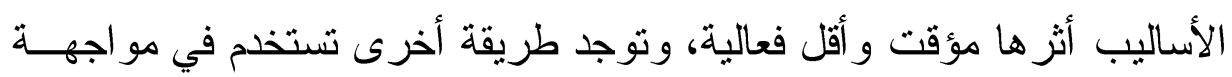

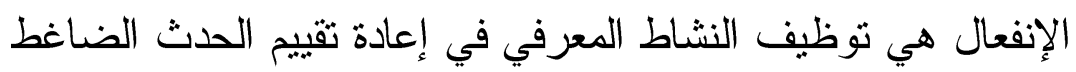

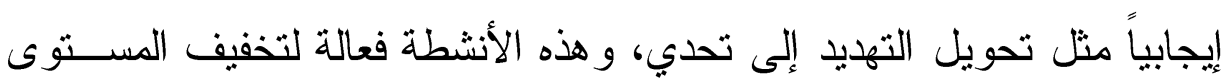

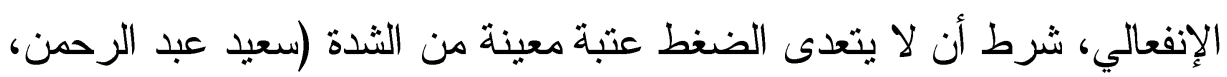

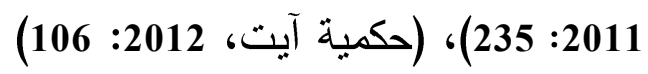


وتشمل تلك الأساليب المركزة على الإنفعال عدة أساليب هـــ، التجنـب،

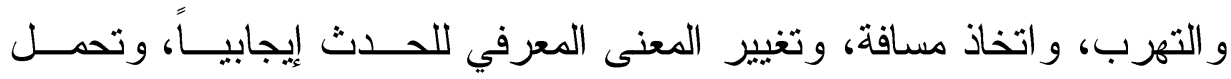

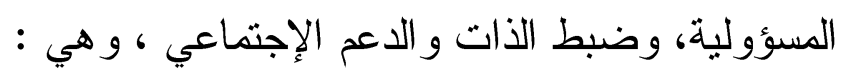

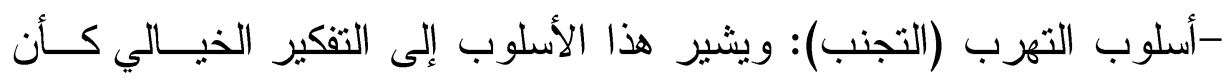

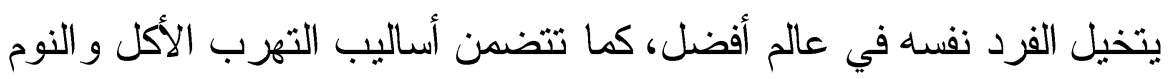

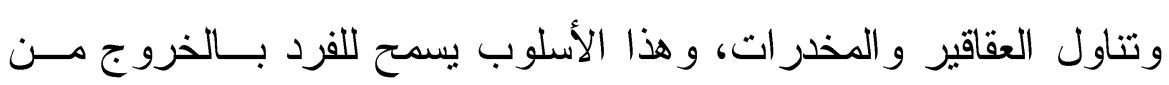
التفاعل الضاغط دون تغييره. - أسلوب ضبط الذات: ويشير هذا الأسلوب إلى التركيز على التنظيم الوجداني دفيره

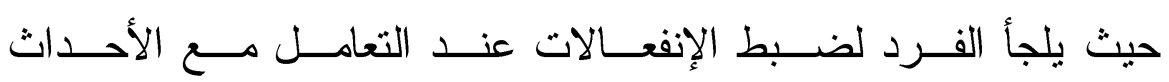
الضاغطة.(بشير الرشيدي، و آخرون، 2001: 147)

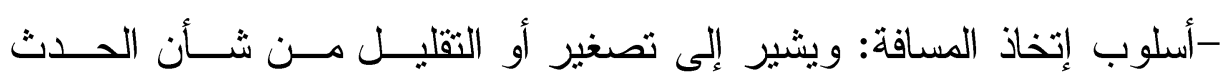
الضاغط. - أسلوب تحمل المسئولية: ويشير إلى إحساس الفـرد ووعيـهـ بالمســؤولية الشخصية في الحدث الضاغط. - أسلوب إعادة التقدير الإيجابي: ويشير إلى المجهودات المعرفية التي يحاول فيها الفرد إعادة ثقييم الحدث إيجابياً.

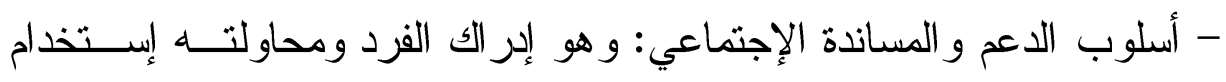

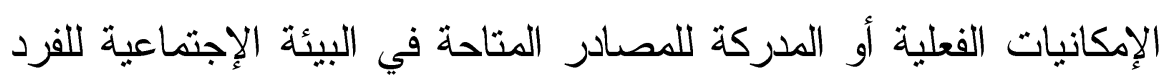

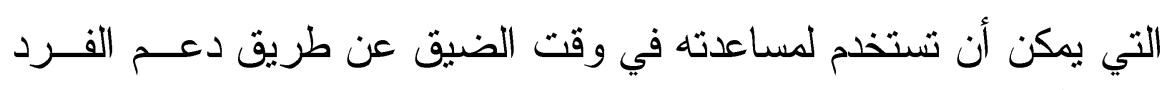
وجدانياً للتخفيف من الحدث الضاغط و آثاره وتشمل هذه المصادر الأسرة

$$
\text { و الأصدقاء. (حكيمه آيت، 2012: 106) }
$$

ويذكر طلعت أحمد (2008) مجموعة أساليب أخرى معرفيــة و إنفعاليــة

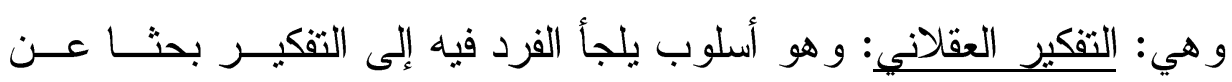

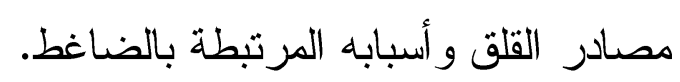


مالإنكار: وهي عملية معرفية يسعى الفرد إلى تجاهل الحدث الضاغط.

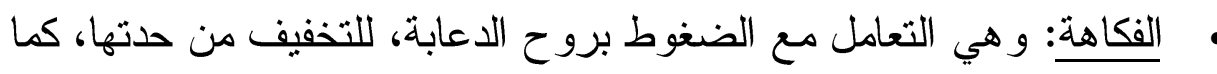
أنها تؤكد على الإنفعالات الإيجابية أثناء المو اجهة.

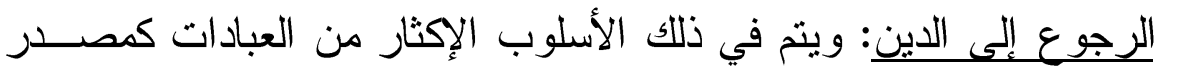
للاعم الروحي و الإنفعالي لمو اجهة الحدث الضاغط. •الإلتفات إلى اتجاهات و أنشطة أخرى: حيث يقوم الفرد بإعادة تنظيم حياتــهـ من جديد بعد الحدث الضاغط و الإهتمام و التفكير في أثنياء جديدة يستمتع بها باعها

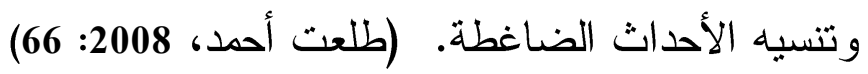
ويتفق محمد السيد (2012) مع طلعت أحمد في تحديد أساليب المو اجهــة ولكنه يزيد عليها بعض الأساليب السلبية ومنها التقبل أو الإستسلام، و التنفيس الإنفعالي .(محمد السيد، 2012: 120) وتزى الباحثة أن أساليب مو اجهة الأحداث الضاغطة يمكن أن تصنف إلى الى الى الفي

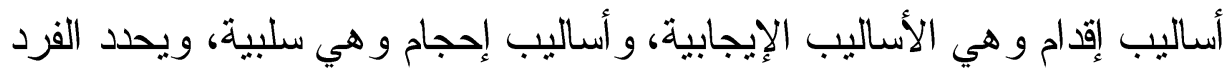
أسلوب مو اجهته لأحداث الحياة الضاغطة من خلال سماته الثخصية و النفسية وسياقه الثقافي و الإجتماعي، كما أن شدة وخطورة الحدث وحجمه يلعبو الدوراً

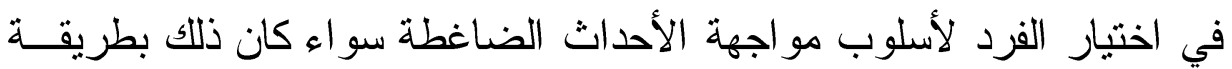
شعورية أو لا شعورية. ويؤكد ما سبق نتائج در اســـة إدو ارد ورميـرو Edwards \& Romero (2008)

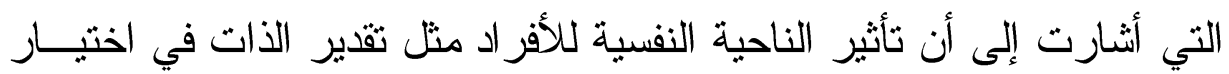

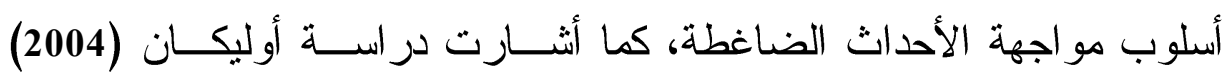
Oleakan في ذلك الر أي عبد الحميد حسن و آخرون (2007)، وقد أظهرت دراسة بيسلي

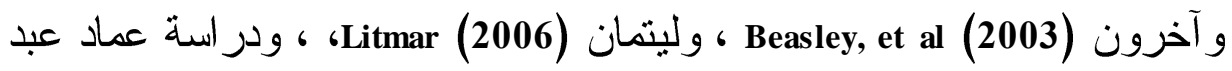

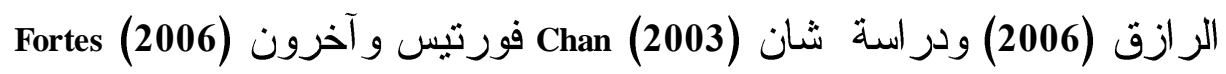




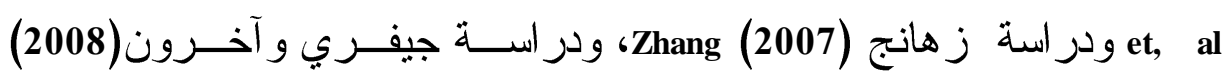
Jeffry,et,al

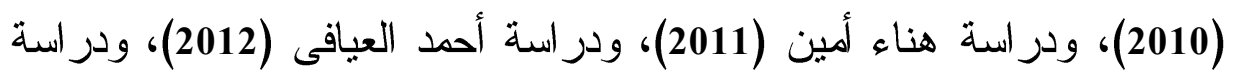
محمد عبد الوهاب (2012)، ودراسة خالد العبدلي (2012)،ودر اسة عند عبد المنعم

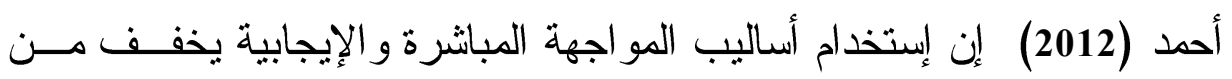
تأثير ات أحداث الحياة الضاغطة، ويؤثز إيجابياً في الصحة النفسية للفرد.

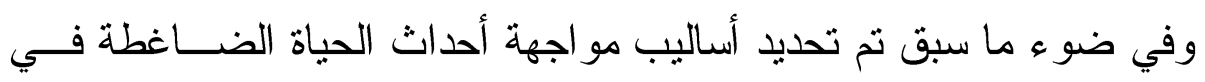
الار اسة الحالية في خمس أساليب رئيسية تثتمل على مهار ات و أنشطة فرعية،

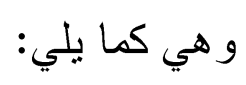

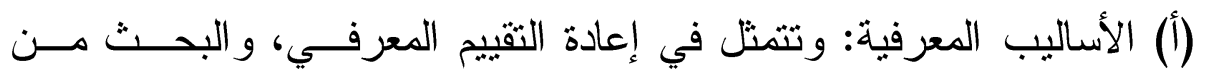

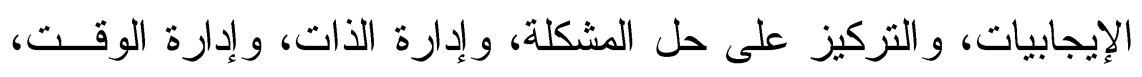

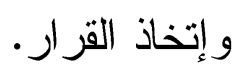

(ب) الأساليب الإنفعالية: وتهدف إلى تقليل الأثر الإنفعالي للحدث الضاغط

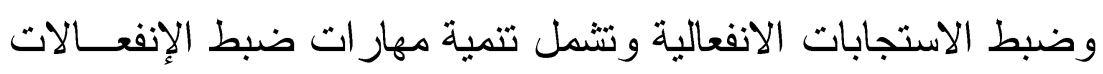
وتحمل الفرد المسؤولية وتحديد لدوره في المشكلة، الالتفات إلى أنثــــة الإنة أخرى لخفض التوتر، وحديث الذات الإيجابي،و تجاهل الششكلة و الفكاهة.

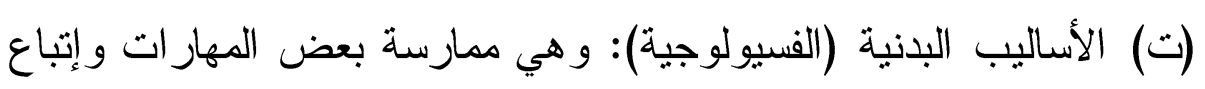

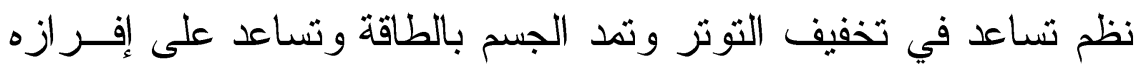

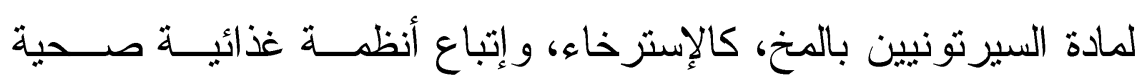
وممارسة الرياضة.

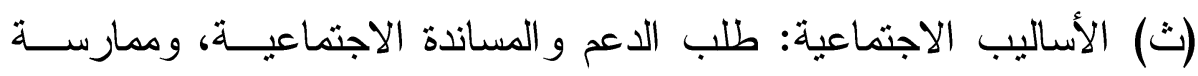

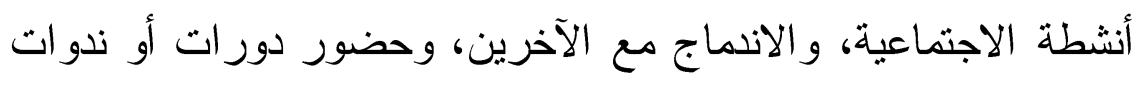
طلب المساعدة من المختصين. 
(ج) الأساليب الدينية: وتتمثل في التماس العون من الله عن طريق اللجوء لله

$$
\text { - أثر الأحداث الضاغثار من العبادات، و الدعاء. }
$$

يوضح محمد عمرو (2007)، سعاد سليمان (2008) ،أحمد العيافي (2012) أن التعرض المستمر للضغوط يؤدي إلى الأعر اض التالية:

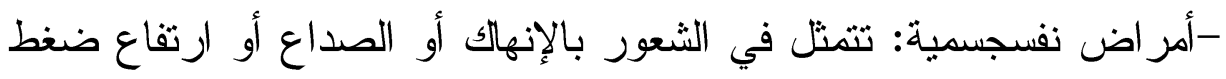
الدم أو زيادة، ضربات القلب، مما ينعكس بالسلب على مستوى أداء الفرد.

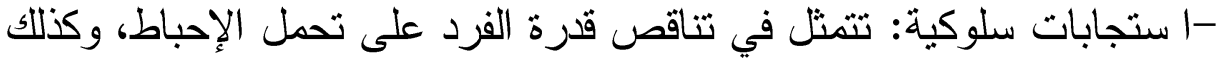

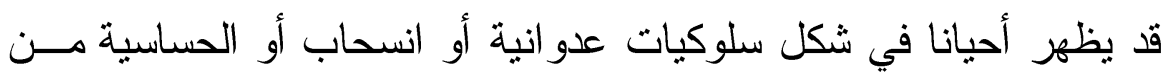
المو اقف.

كما تعمل الضغوط كعامل مساعد في ظهور العديد مــن الاضــطر ابات كالقلق و الاكتئاب، وقد يتطور الأمر في أسو أ الظروف فهول إلى الفصام أو الانتحار

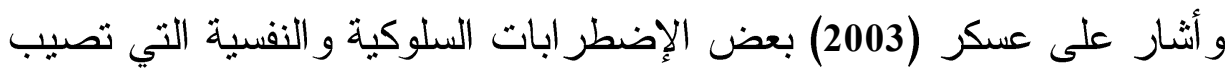

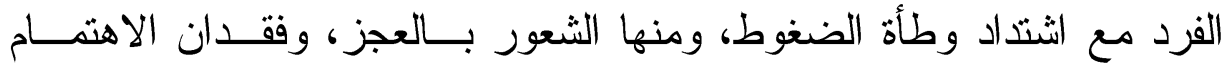
بالآخرين و العمل، و السخرية من الآخرين، و الإكتئاب و السلبية و الثكك في قيمة الحياة. وفي ضو ء ما سبق فإن ليس كل ضغط سيئاً، حيث توجد مسـتويات مــن

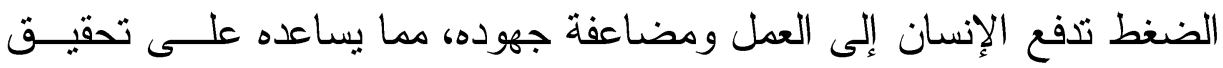
أهدافه وشعوره بالإنجاز أو ما في حالة زيادة شدتها فإنها تصبح سلبية وتؤدي الإني إلى أمر اض جسمية و إضطر ابات نفسية.

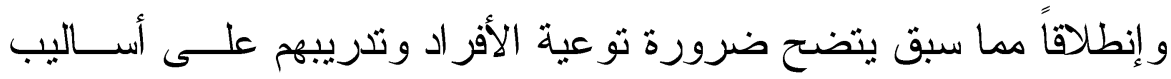

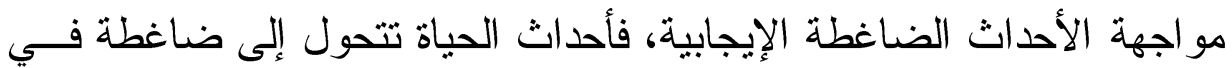

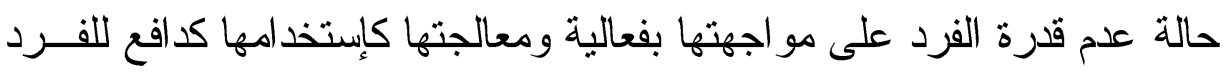


على العمل و الإبتكار مما ينتج عنه في النهاية شعور الفرد بالإنجاز، ومعنـى

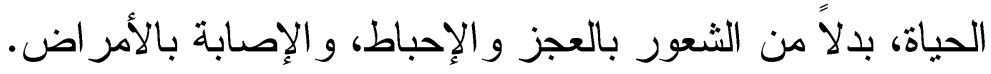

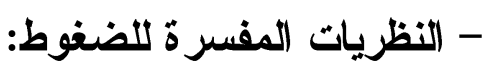

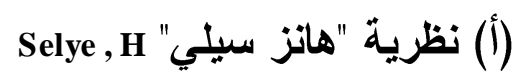

أثارت بشرى إسماعيل (2005) إلى أن سيلي في نظرية الجهائ رأى أن كل

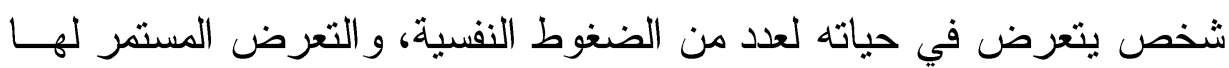
يؤدي إلى تأثير سلبية تظهر في صورة استجابات فسيولوجية أطلق عليها زملة

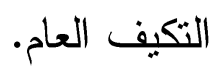
وقد حدد سيلي ثلاثة مر احل لمو اجهة الضغط النفسي هي:

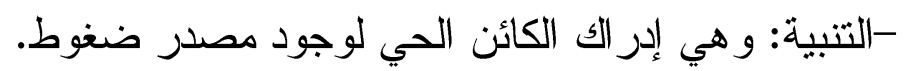
-المقاومة: و هي مرحلة مو اجهته مصدر الضغوط، فيبدأ الجسم في إفــــراز

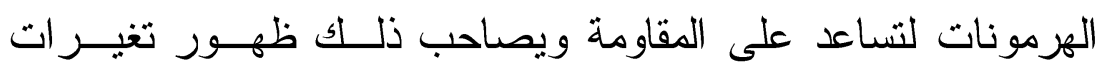

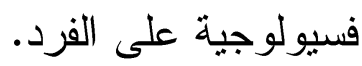
-الإنهالك: ينكلك الفرد من استمر ار مواجهته لمصدر الضغط ويعجز عـن الاستمر ار فيحدث الإنهيار .(محمد عيد، 2005: 67)،(نايف أحمد، 2012:

(ب) نظرية "ولتر كانون" (بnnon, W.

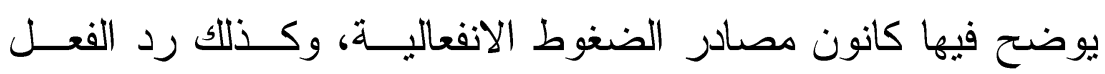

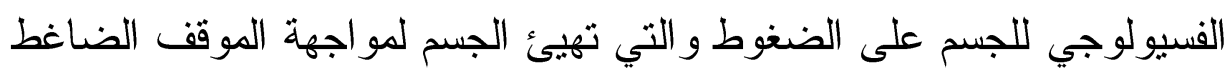

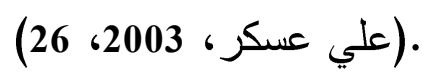
(ج) نظرية "هولمز و راه" Halmas \& Rahe

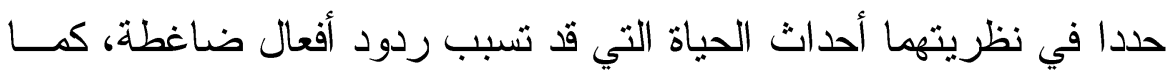
أثنار إلى ردود الفعل للضغوط (حسن مصطفى، 2006: 28) (د) نظرية سبيلبرجر Spielberger: 
وتعرف نظريته بالإدر الك الكلي للموقف، وتشير إلى أن الدافع يلعـب

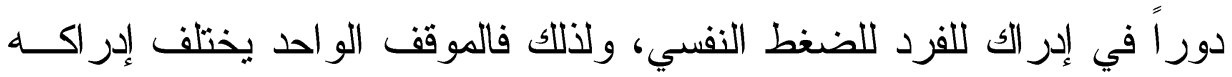

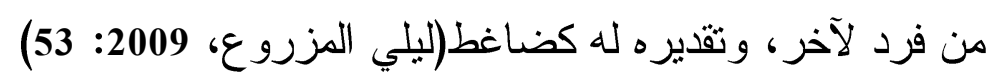

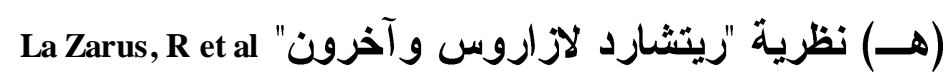
سمي "لاز اروس" نظريته بنموذج التقييم المعرفي، وفيهـيه يتم التمييز بــين

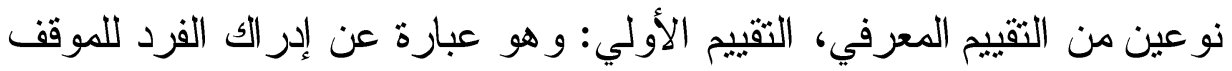

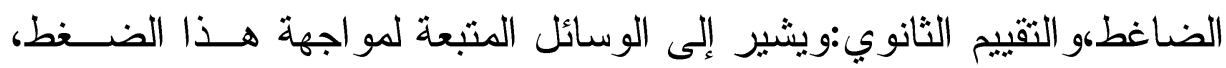

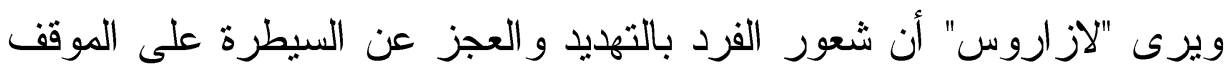
الضاغط يتوقف على تقييمه المعرفي لهذا الموقف، ويقسم الضغوط وله إلى نوعين، أحدها يعرف بالأحداث الضاغطة الخارجية : وهي الأحداث الناتجة عن البيئة

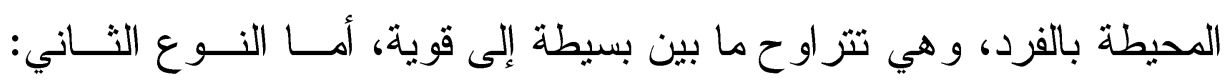

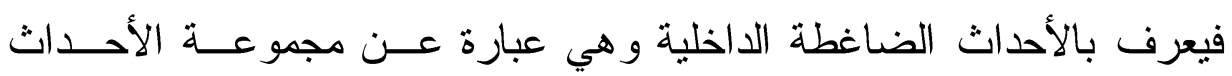

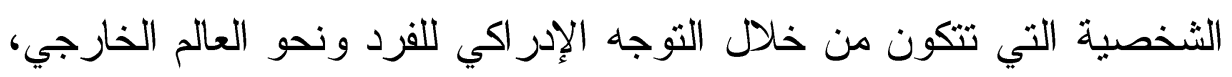

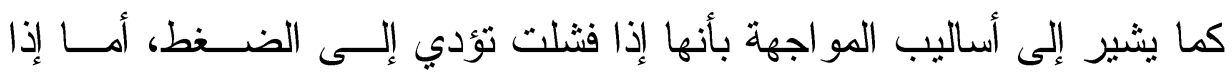

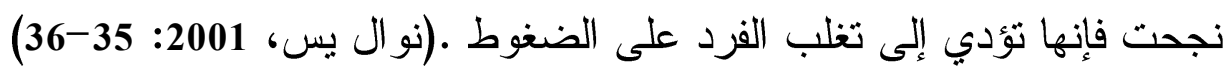

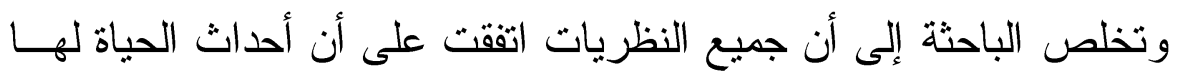

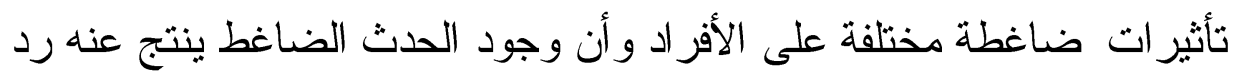

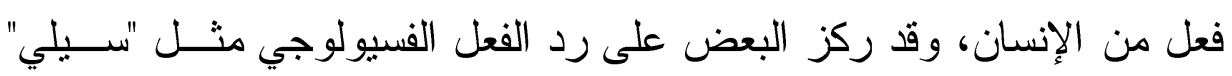

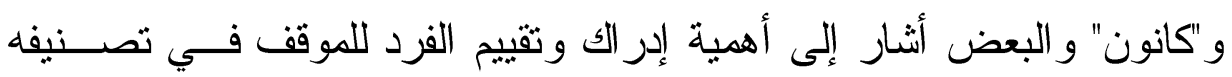
كحدث ضاغط أي أن الحدث الضاغط يتطلب من الفرد استجابة تكيفيه كــرد فعل على الحدث الضاغط. ويشير محمد حسين (2010) إلى أن أساليب المو اجهة هي عملية إعادة إدر الك

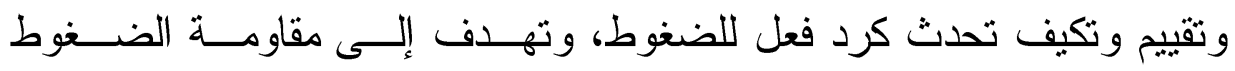

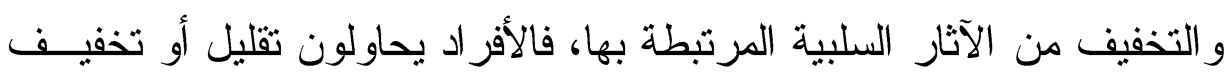


الضغوط بو اسطة التفكير و الثعور أو السلوك بطرق متعددة لمو اجنتها، و هـــه

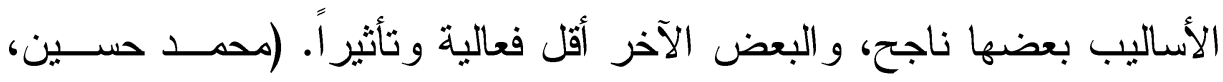

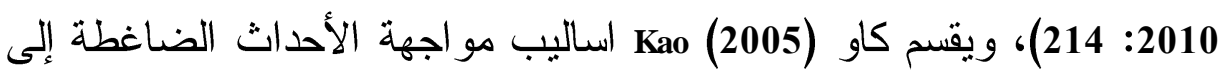
ثلاثة أساليب و هي:

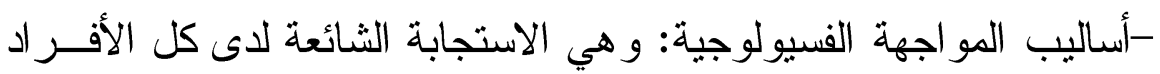

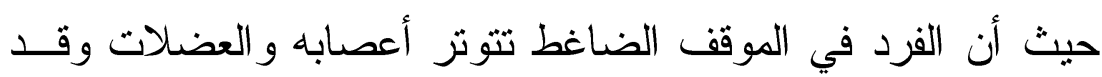

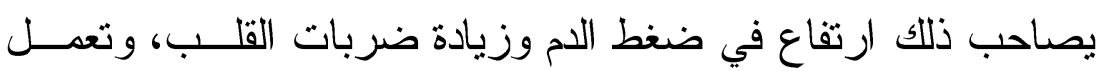
أساليب المو اجهة الفسيولوجية على القضاء على هذه الأعر اض، ومنها التمارين الرياضية، وكذلك الاسترخاء.

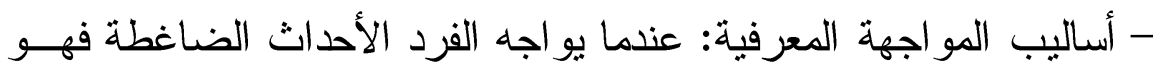

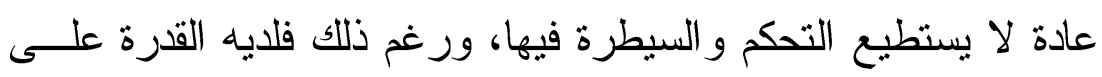

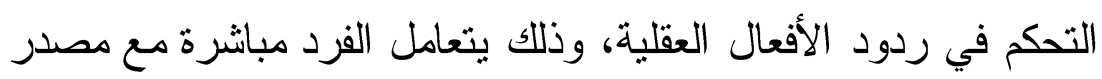
الحدث الضاغط و التعرف على المشكلة و إيجاد حل لها.

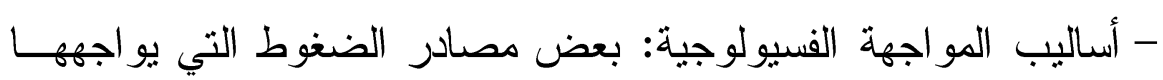

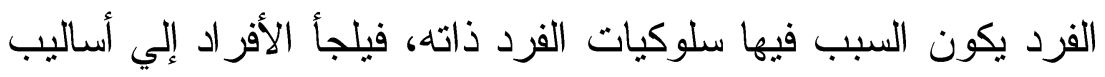

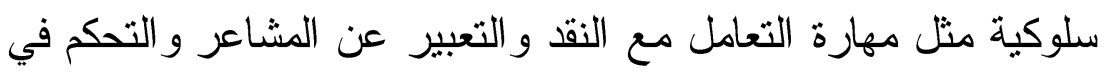
الغضب.(محمد حسين، 2010: 214) ويلخص عبد المنعم حسيب أساليب المو اجهة في ثلاثة أساليب هي:

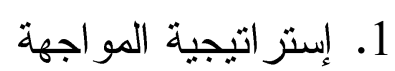
2. إستر اتيجية التماس العون

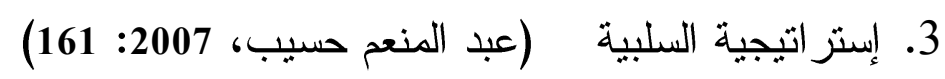
• ثلاثثاً: اللدر اسات (لسابقة:

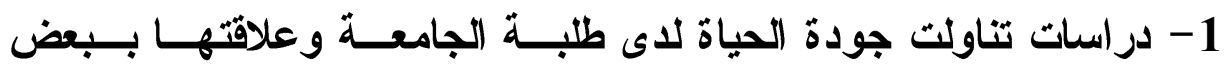
المتغير ات: - (ات 
- قامت جافالا Gavala (2005) بدر اسه هدفت إلى الكثف عن العلاقــة بـين

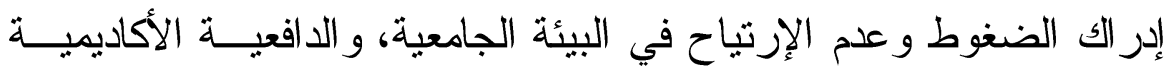

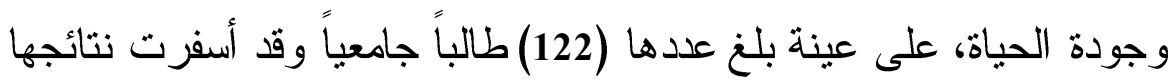

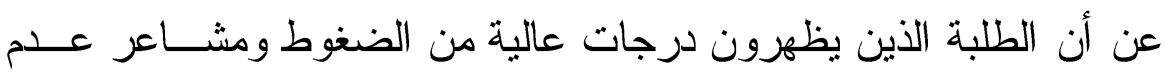
الر احة في الجامعة ومستوى منخفض في السيطرة الأكاديمية كان شعور هم بمستوى جودة الحياة منخفض وكذلك في الدافعية الأكاديمية.

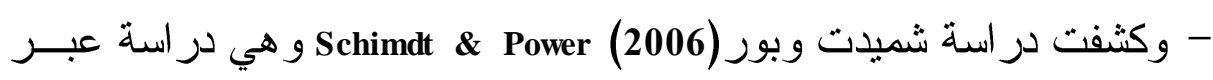

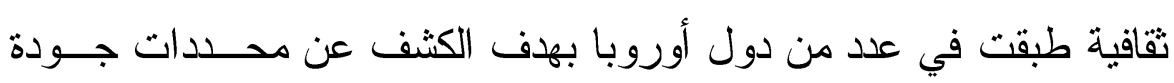
الحياة والصحة النفسية لدى الأوربيون، وتكونت عينة الدر اسة من (4849)

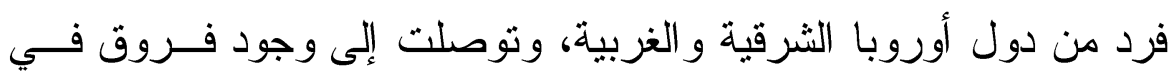

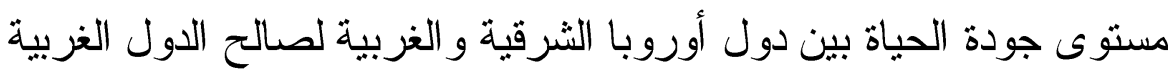

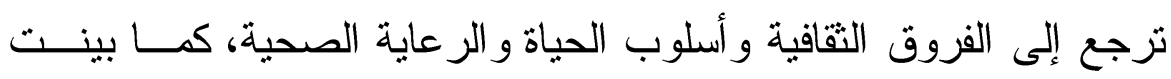
النتائج أن الصحة النفسية عامل قوى للتنبؤ بمستوى جودة الحياة. - وقام حسن عبد الحميد و آخرون (2007) دراسة هدفت إلى معرفة مستوى فئل

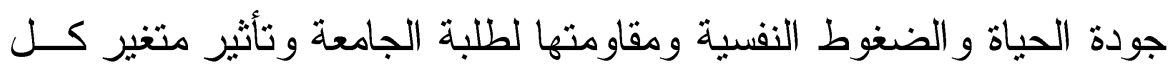
من الجنس ونوع الكلية عليهم، وتكونت عينة الدر اسة مــن (183) طالبـاً وطالبة من جامعة السلطان قابوس، وكثف نتائجها عن وجود مســتويات

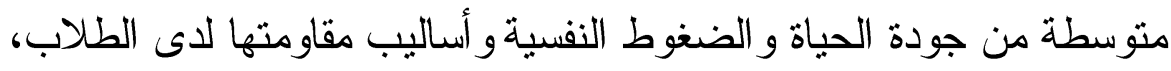
كما أظهرت وجود فروق بين الجنسين في مستوى جودة الحيـاة لصــالح الذكور ، ولصالح طلبة الكليات العملية.

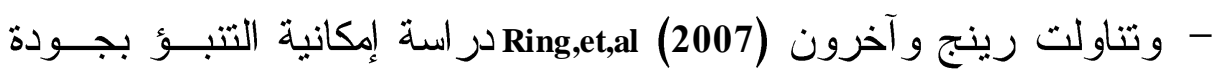

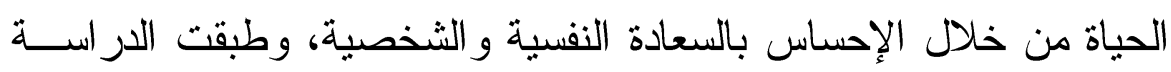
على عينة بلغت (136) طالباً بالجامعة، وتوصلت النتائج إلي وجود علاقة الإدة وطنة 
بين كل من السعادة النفسية و الشخصية و الثعور بجودة الحياة، كما تبـين إمكانية التنبؤ بجودة الحياة من خلال الإحساس بالسعادة لدى الطلاب.

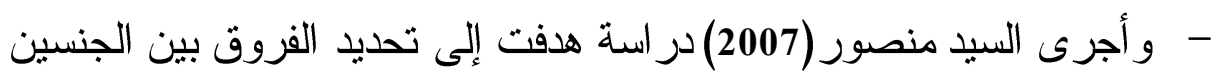
و التخصص و السن في جودة الحياة، و الفرق بـين منخفضــي ومرتفعسي

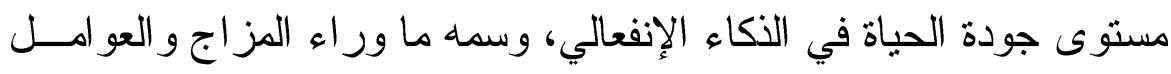
الخمسة في الشخصية و القلق، وطبقت الدر اسة على عينة بلغ عددها (403)

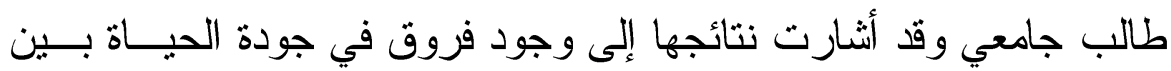
الجنسين لصالح الإناث، ولصالح طلبة الأقسام الأدبية، كما كثفت النتـائج

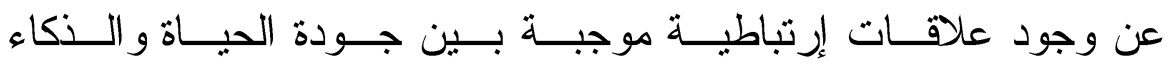

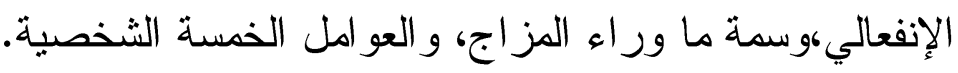

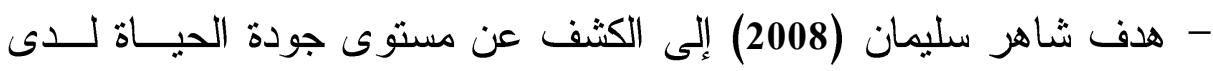
طلاب الجامعة في تبوك في ضوء متغير ات التخصص و التقــدير ودخــل الأسرة و اشتملت العينة على (649) طالباً من جامعة تبوك، وقد فئر بينت النتائج إن بعض مستويات جودة الحياة كانت مرتفعة لدى الطلاب في بعدي الحياة الأسرية و الحياة النفسية بينما انخفض مستوى جودة الحياة في بعدي الحياة التعليمية و إدارة الوقت، وكان متوسطاً في الصحة العامة، بينما وضـــــ الار اسة وجود علاقة ارتباطية بين جودة الحياة وجــودة التعلــيم و الحيــاة الأسرية.

- وأجرى هشام عبد الله (2008) در ساسة هدفت للكثف عن جودة الحياة لدى عينة من الر اشدين في ضو هُ بعض المتغير ات الديمو غر افية، وتكونت العينة

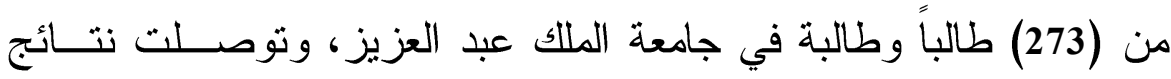

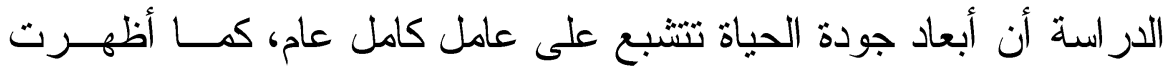
النتائج وجود فروق بين الجنسين لصالح الطلبة الذكور ، كما كثفت النتائج أن الصحة النفسية عامل قوى للتنبؤ بمستوى جودة الحياة. 
- ووضح عصام عبد العزيز (2008) العلاقة بين مؤشــرات جـودة الحيــاة ومؤشرات الصحة النفسية لدى طلاب الجامعة وطبقت الدراسة على عينة

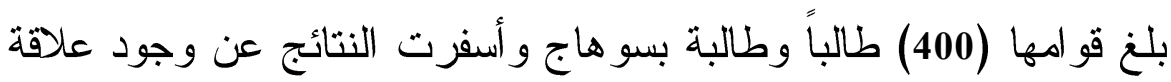

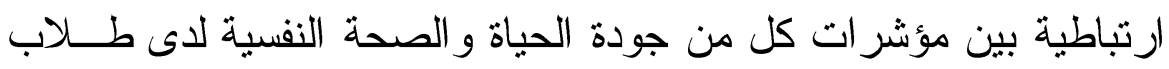
الجامعة.

- وقام يجر اس ولي (2008) - Yu, Grace \& Lee. بدر اسة جودة الحياة الجامعية

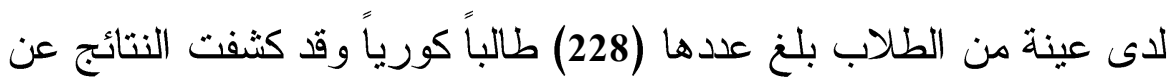

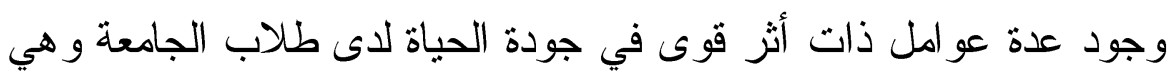
الخدمات التزبوية، و الإدارية و العلاقات السائدة، و التسهيلات الدر اسية.

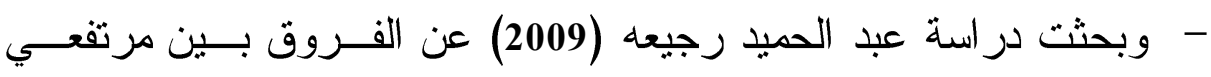
ومنذفضي الذكاء الإجتماعي في جودة الحياة النفسية والتحصيل الدراسي،

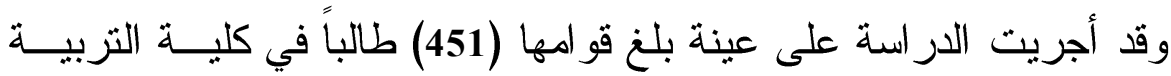
و اثارت نتائجها إلى وجود فروق في جودة الحياة النفسية ل لصالح مرتفعي الأكاء الإجتماعي وكذلك وجود فروق بين الذكور والإناث في جودة الحياة

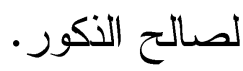
- - وتتاولت اعتدال حسانين (2009) إتقان تعلم علم النفس عن طريق إستخدام

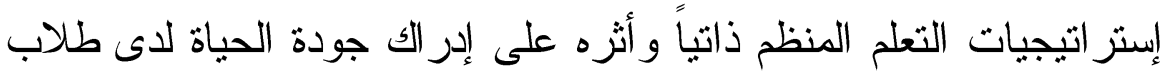

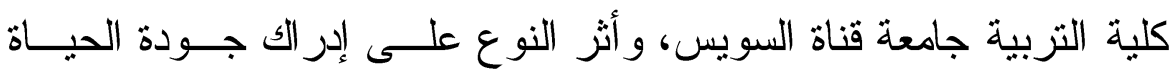
وبلغت عينة الدر اسة (200)طالباً وطالبة وكثفت النتائج إن استخدام أسلوب النّاء

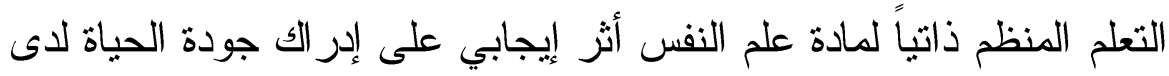

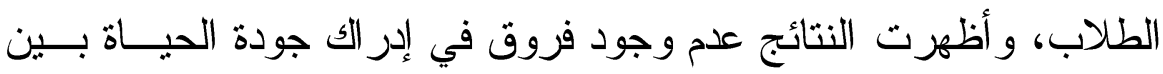
الأكور و الإناث.

- و ت تاولت در اسة هويدا حنفي وفوزية الجمـالي (2010) فعاليــة الــذات المدركة وتأثير ها على جودة الحياة لدى طلبة الجامعة المتفوقين و المتعثرين 
در اسياً، و اشتملت العينة على (202) طالباً وطالبة من كلية التربية جامعـة

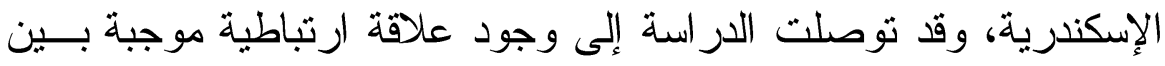

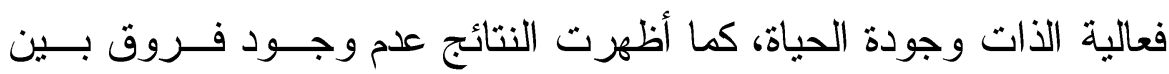
الجنسين في فعالية الذات، وكذلك عدم وجود فروق بين الجنسين في جودة

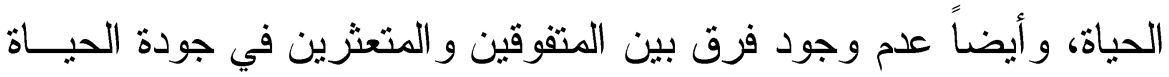
بينما أظهرت النتائج وجود فروق في فعالية الذات بين طلبة الأقسام الأدبية و العلمية لصالح طلبة الأقسام العلمية.

2- دراسات تناولت برامج تحسين جودة الحياة:

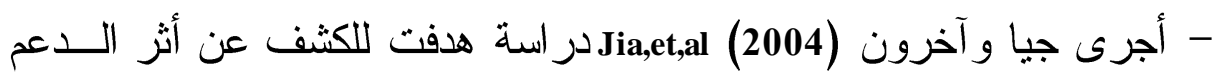
الإجتماعي و التدريب على أساليب المواجهة على الاكتئاب وجود الحيـاة،

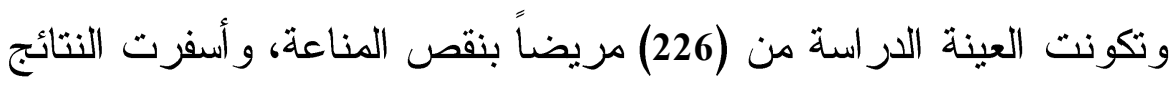

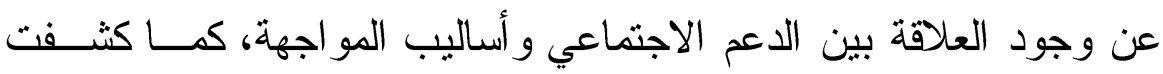
النتائج من تحسن مستوى جودة الحياة و الاكتئاب. - وقدم حسام الدين عزب (2004) برنامجاً لخفض الإكتئابية وتحسين جودة الحياة لدى طلبة كلية التربية، وأجريت الدر اسة على عينة بلغت (30) بلام الباً بكلية التربية جامعة عين شمس وتوصلت النتائج إلى تحسين أبعاد جـودة

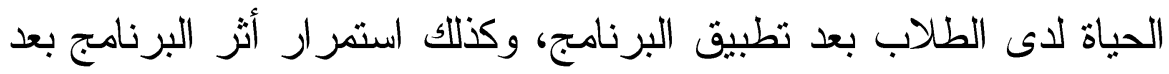
إنتهاء البرنامج.

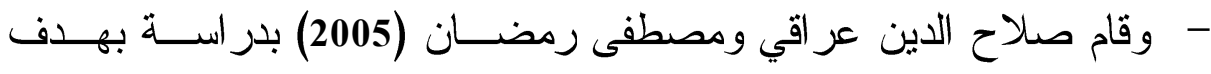

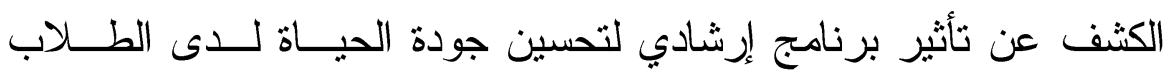

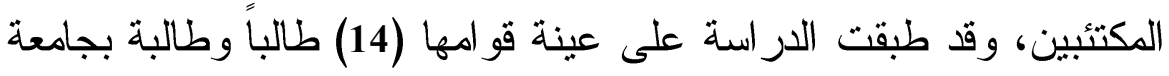
بنها، في كلية التربية، وقد أثنارت نتائج الدراسة إلى تحســين البرنــامج لمستوى جودة الحياة لاى الطلاب وخفض الأعر اض الإكتئابية. 
- ـ و أجرى صلاح الدين عر اقي (2006) در اسة للكثف عن فعالية برنــامج

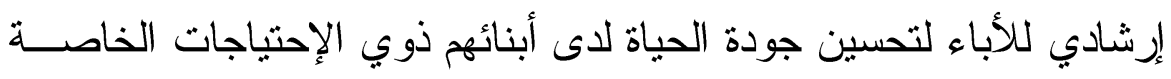
(من فئات الإعاقة السمعية و البصرية و العقلية)، وبلغت عينة الدراسة (11) من أباء الأطفال ذوي الإحتياجات الخاصة، وقد أسفرت نتائجها عن فعالية

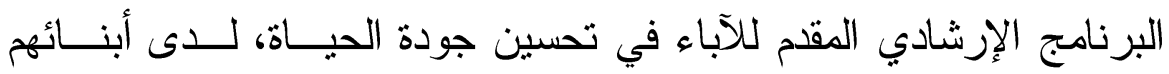

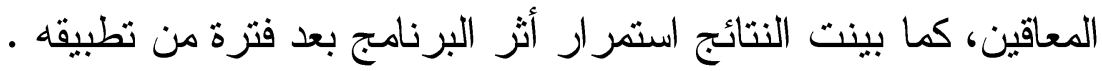
_ وقامت هانم محمد (2009) در اسة لإستخدام برنامج إرشادي قائم على نظرية

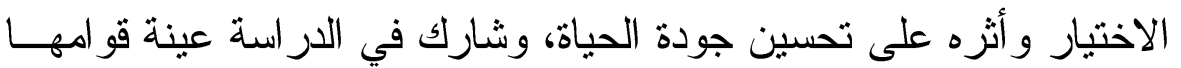
(21) طالبة بالمرحلة الثانوية بمدينة الإسماعيلية، وكثفت النتائج عن فعالية البرنامج في تحسين جودة الحياة لدى الطالبات، كما بينت النتائج إمتداد أثز البرنامج بعد إنتهاء تتفيذه من خلال القياس التتبعي.

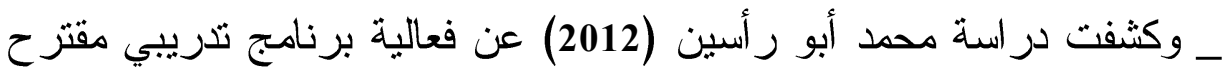

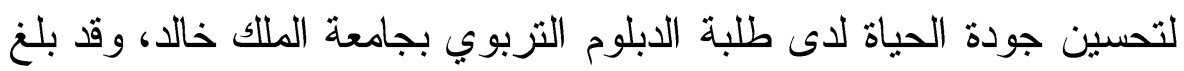

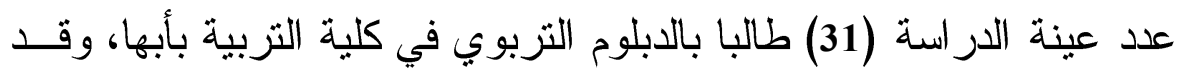

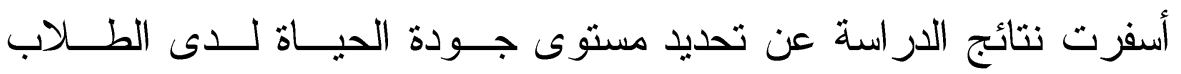
بالمتوسط، ما عدا في بعد التعليم فكان فوق المتوسط، كما أظهرت النتــائج

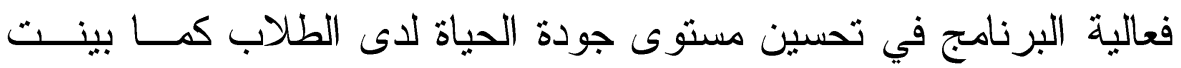

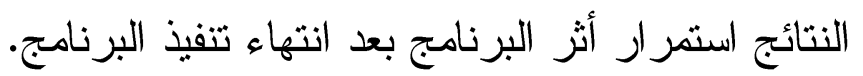

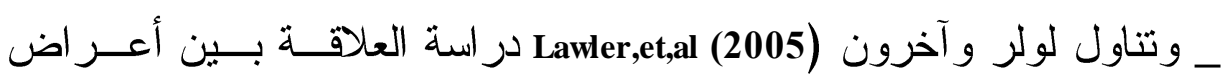
اضطر اب الضغط و أساليب المو اجهة و الحالة الصحية و البدنية لدى طلاب الجامعة، وكانت العينة قو امها (138) طالب وطالبة جامعيين من المترددين

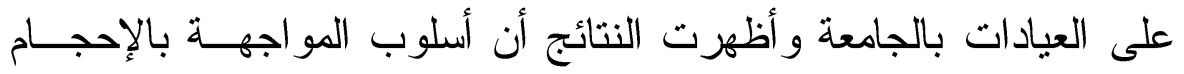
ارتبط بضعف الحالة الصحية كما تبين أن الطالبات الأكبر سناً أكثر معاناة من الضغوط من الصغير ات. 


\section{3- دراسات تناولت أساليب المواجهة:}

_ أجرى مارك و آخرون Mark,et,al (2002 در اسة لاكتشاف العلاقة بين جودة

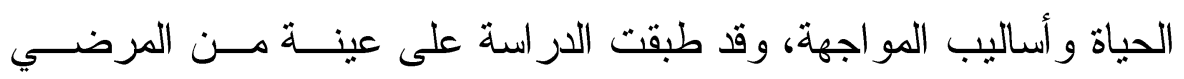
بمرض نقص المناعة بالمستشفيات، وأسفرت نتائجها عن التأثير الإيجابي ولي

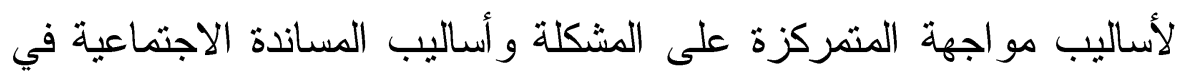
تحسين جودة الحياة. ـ وقدمت منى عبد الله (2002) در سأة بهدف التعرف على أساليب مو اجهــة

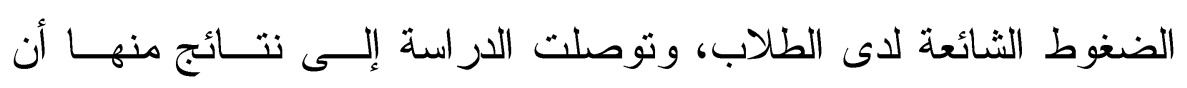
الأساليب السلبية في مواجهة الضغوط احتلت المر اكز الأولى في الأساليب

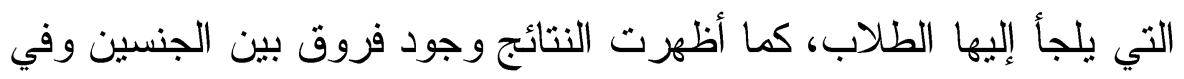
مر احل التعليم المخلتفة في أساليب المو اجهة، وقد طبقت الدراسة على إسى عينة قو امها (1073) طالباً وطالبة. ـ و أجرى هيمان Heiman (2004 در استة تتاولت فيها العلاقة بــين المصــادر النفسية و إدر الك الضغوط و أساليب مواجهة المشكلات لاى طلاب الجامعة،

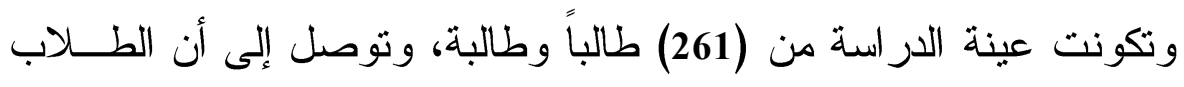

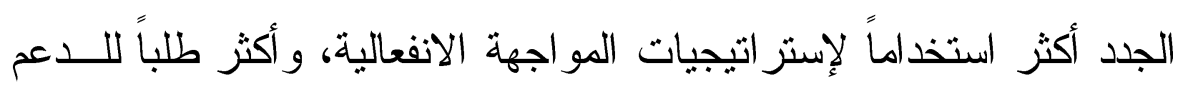

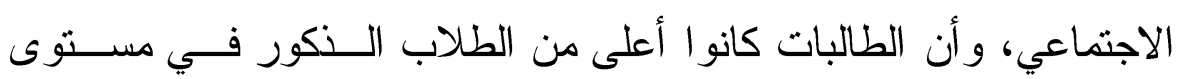

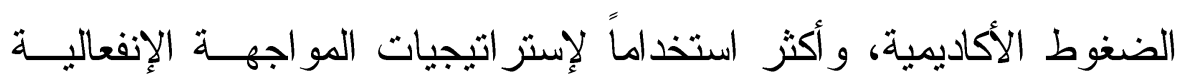
خاصة الإحجام. _ وتتاولت نعيمة الرفاعي (2004) در اسة عن مستوى تحقيق الذات في علاقته

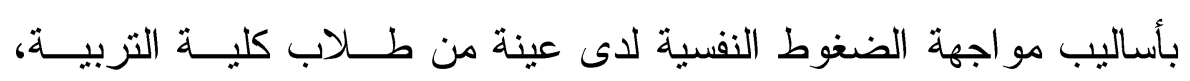

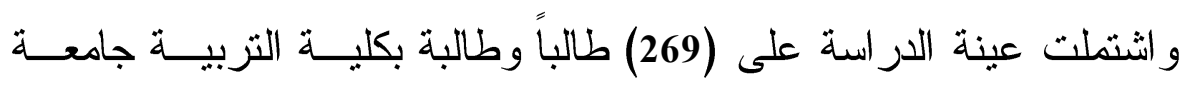
المنوفية، وكثفت النتائج من وجود فروق بين درجات مرتفعى ومنخفضي

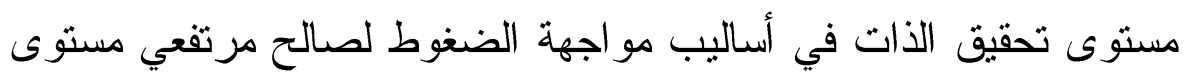


تحقيق الذات، كما أظهرت النتائج عدم وجود فروق بين الذكور و الإنــاث

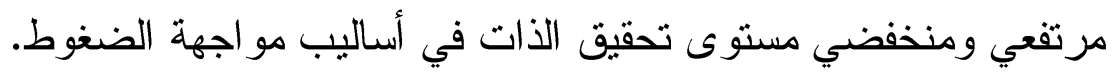

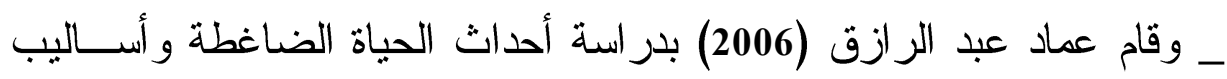

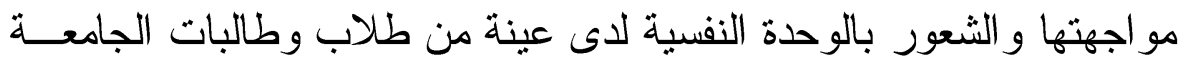

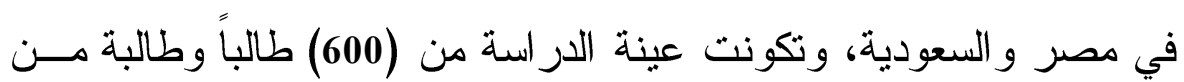

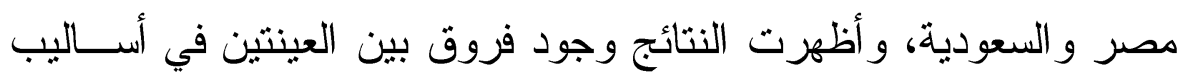

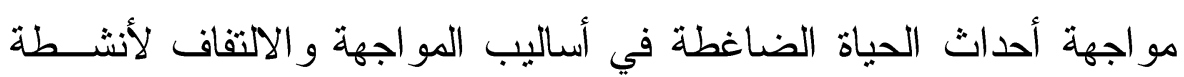
أخرى و التجنب و الإنكار و العلاقات الاجتماعية وتتمية الكفاعة الذاتية لصالح

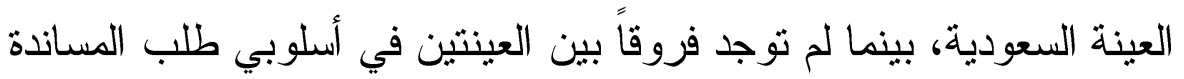

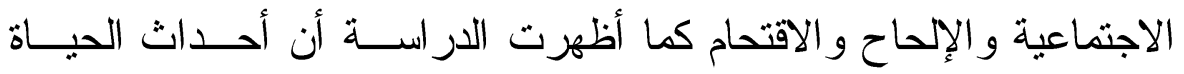
الضاغطة الأسرية و العلاقة بالجنس الأخر هي من أقوى أحسـداث الحيــاة الضاغطة.

- وبحث عبد المنعم حسيب السيد (2007)عن العلاقة بين الذكاء الوجــداني

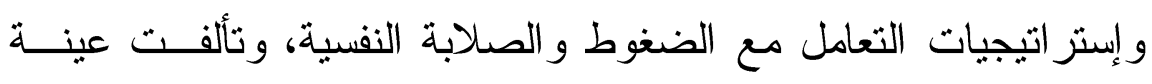

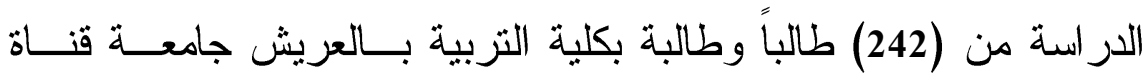

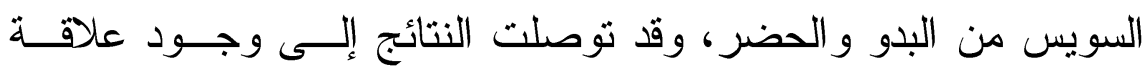
ارتباطية موجبة بين إدارة الانفعالات و إستر اتيجية المو اجهة، كما أظهرت

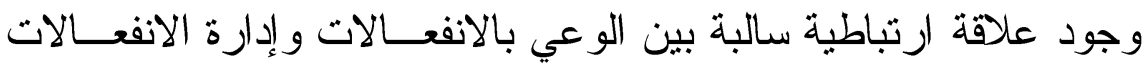

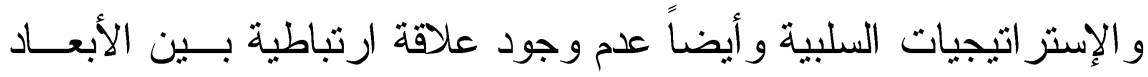
المختلفة للذكاء الانفعالي و إستر اتيجية إلتماس العون. - و أجرى علي الثكعة (2009) در اسة هدفت إلى التعرف على درجة استخدام

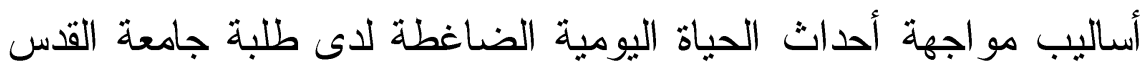

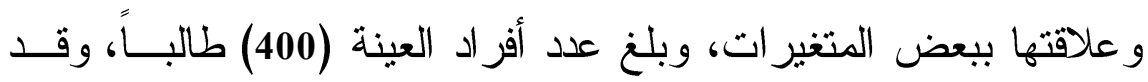

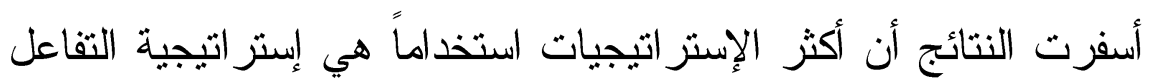


الإيجابي يليها التصرفات السلوكية و آخر ها إستر اتيجية التفاعل السـلبي، البها،

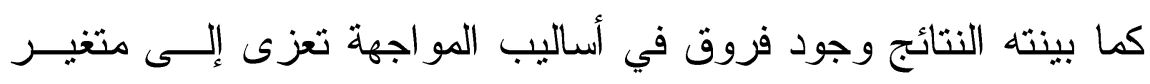
الجنس فكانت أساليب التفاعل السلبي الفروق فيها لصالح الإناث.

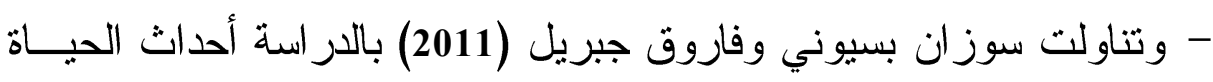

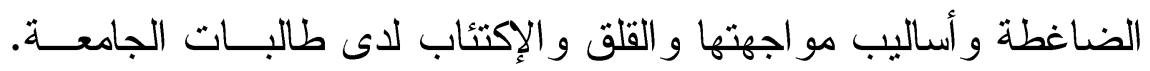
تكونت عينة الدراسة من (770) طالبة من كلية التربية بالمنصورة وكلية

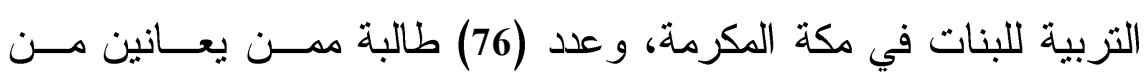

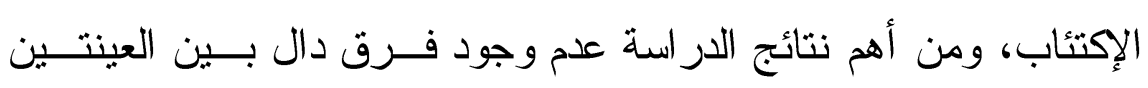

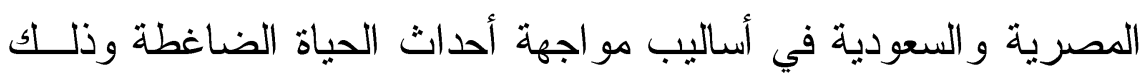

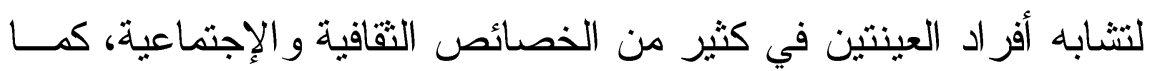

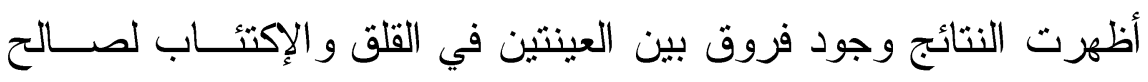
العينة المصرية. - و هدفت حكيمة آيت (2012) لدراسة دور أساليب المو اجهة في التعامل مع

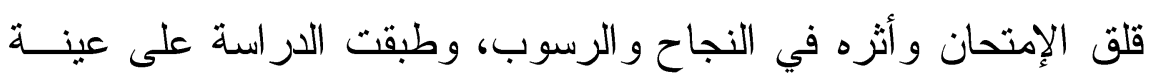

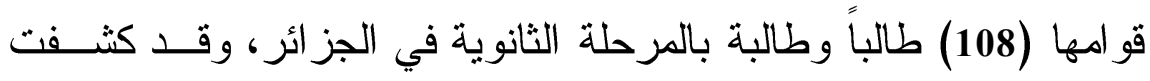

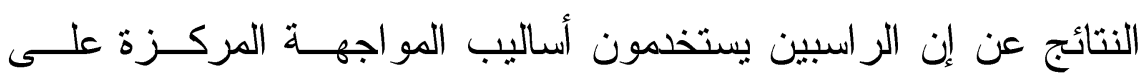

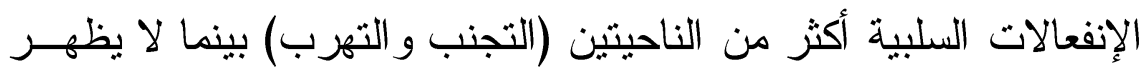

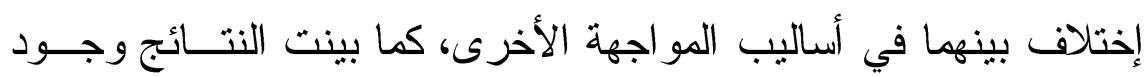
ارتباط بين أساليب المو اجهة المركزة على الإنفعال وقلق الإمتحان.

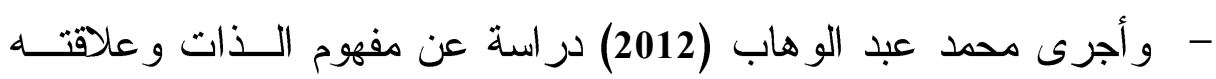

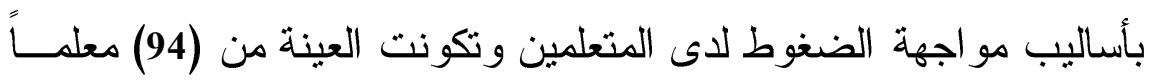

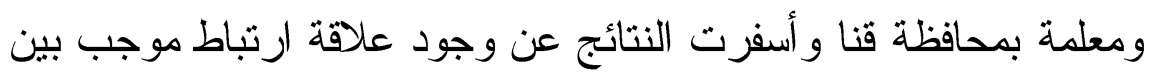

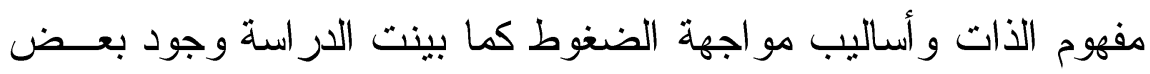

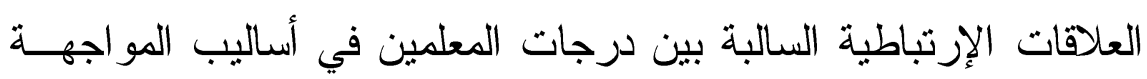


ومفهوم الذات كما توصلت الار اسة إلى وجود فــروق بــين المعلدـين

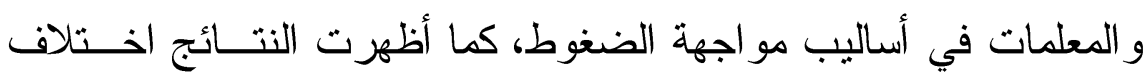

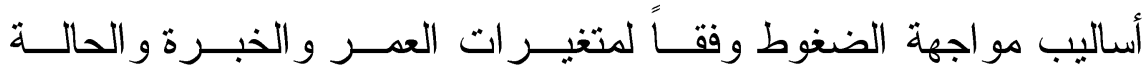
الإجتماعية.

4- دراسات تناولت برامج وتأثير ها أساليب مواجهة الأحداث الضاغطة:

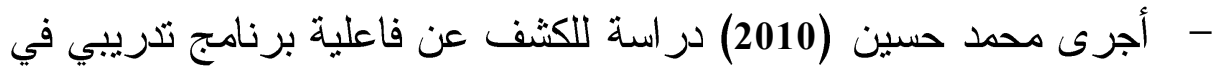

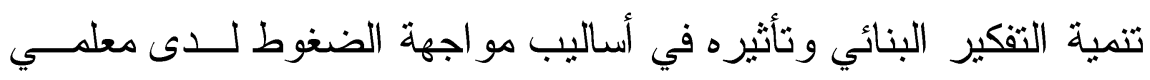

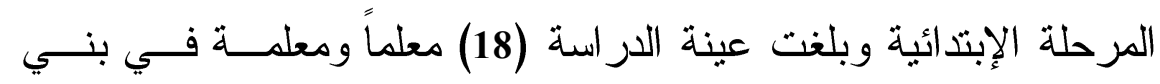

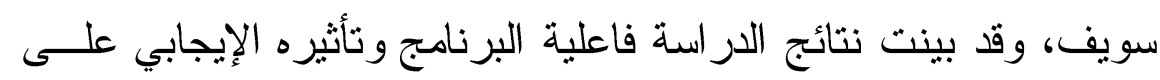

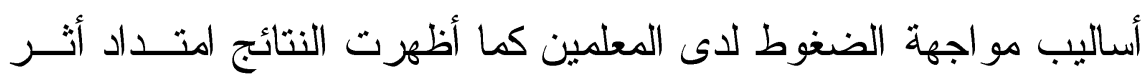
البرنامج في القياس التتبعي بعد الإنتهاء من تتفيذه.

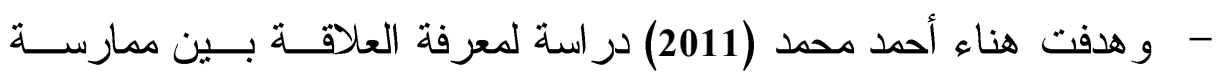

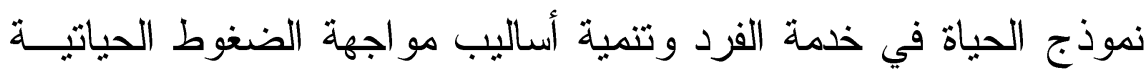
للطالبة الجامعية المتزوجة، اشتملت عينة الدر استة علــى (10) طالبــات متزوجات من كلية الآداب جامعة الملك سعود وتوصلت النتائج إلى فعالية التئه

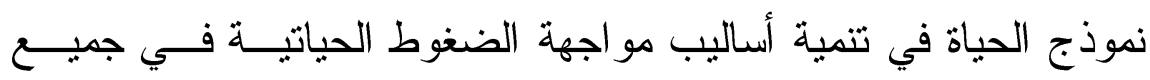
الأساليب و هي السلوكية و المعرفية و الانفعالية و الروحانية.

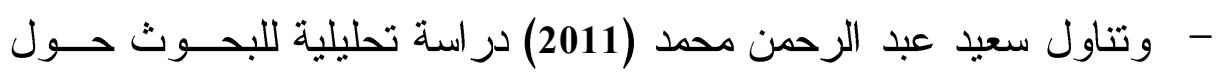

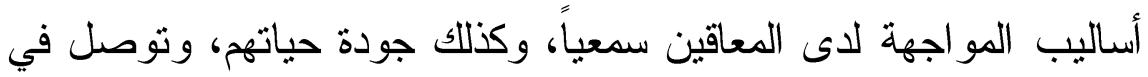

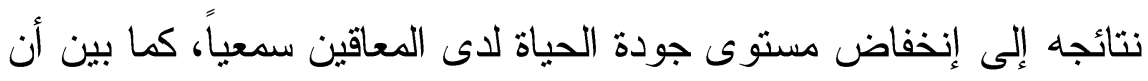
بعض أساليب المواجهة قد تساعد في تحسين شعور هم بجــودة الحيــاة،

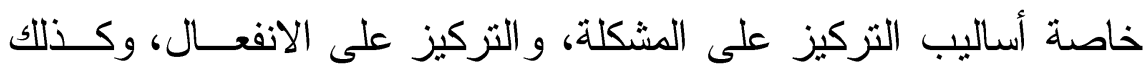

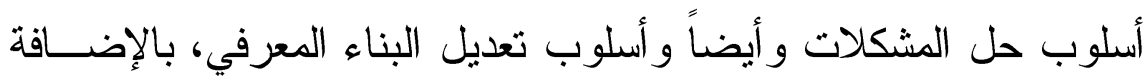

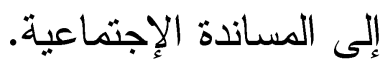


- - وقام عبد المنعم علي (2012) بدر اسة للكثف عن العلاقــة بــين الـــكاء

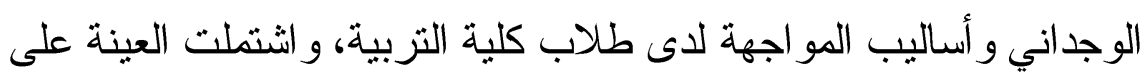

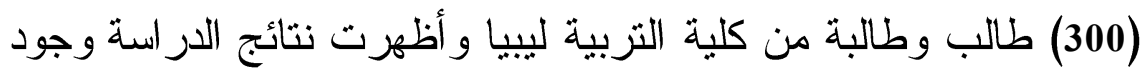

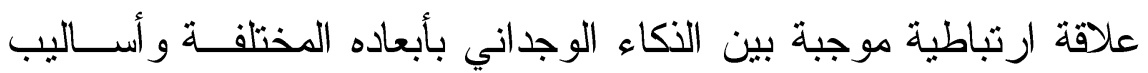

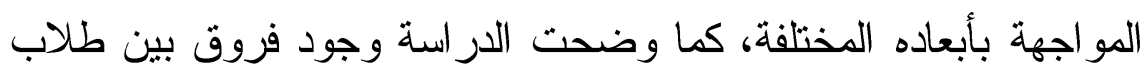
الفرقتين الأولى و الر ابعة في أساليب المو اجهة، وكذلك فروق بئ ولين الجنسين

$$
\text { في أساليب المو اجهة. }
$$

- - وقام نايف الحمد (2012) برنامج إرشادي لمو اجهة الضغوط النفسية للطلبة

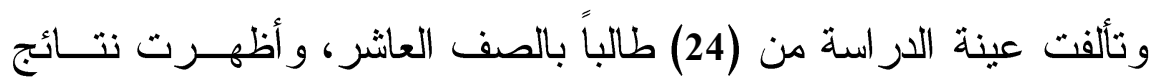

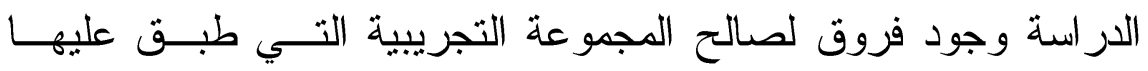

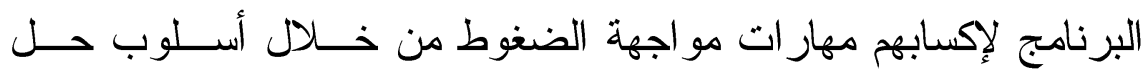
المشكلات و التحصين ضد الضغوط و أظهور النتائج فاعلية البرنامج. - تطليق عام على الاراسات السابقة: 1. استخدمت معظم الدر اسات في در اسة جودة الحياة المنهج الوصفي للكثف الثفاتفه

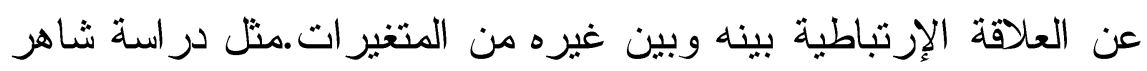
سليمان (2008)، هشام عبد الله (2008)، هويدا حنفي (2010)، عبد المنئ (2008) المنعم

$$
\text { السيد (2007). }
$$

2. قلة عدد الدراسات التي هدفت لإعداد برنامج لتحسين جودة الحياة، حيث

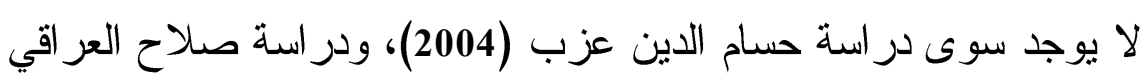
(2005)، ودر اسة هانم محمد (2009) ودر اسة هناء محمد (2012)، ودراسة

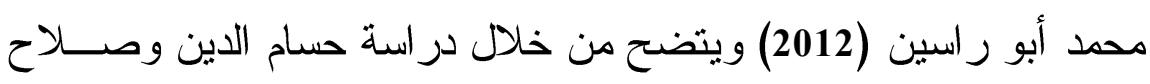

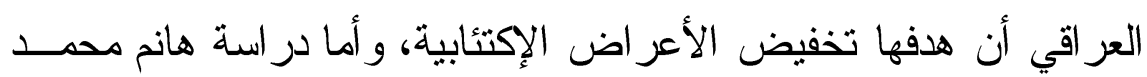

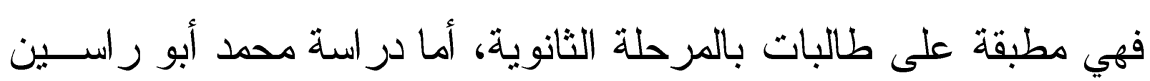
فكانت على عينة من طلاب الدراسات العليا و هدفت لتحسين جودة الحياة 
دون الكثف عن أثزه على متغيرات تابعه أما دراسة هناء محمد (2011)

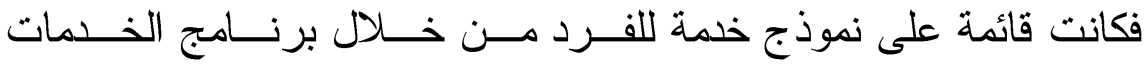
الإجتماعية.

3. اختلفت العديد من الدر اسات حول الفروق بين الجنسين في مستوى إدر الك جودة الحياة، فقد أظهرت بعض الدر اسات انخفاض مستوى جودة الحبــاة لاى الطالبات ومنها در سة حسن عبد الحميد و آخرون (2007)، و هثــام عبد الله (2008)، و عبد الحميد رجيعه (2009) بينما اختلفت معهم نتــائج

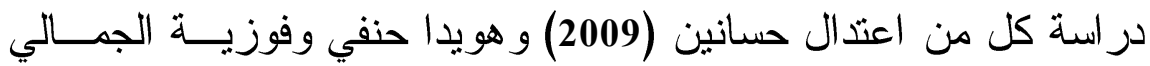
(2010) التي أثنارت لعدم وجود فروق بين الجنسين في وجود الحياة. 4. أظهرت بعض الدراسات العلاقة الارتباطية الموجبة بين جــودة الحيــاة و الصحة النفسية، ومنها دراسة عصام عبد العزيـز (2008)، ودراســـة شميدت وبور (2006)، ودر اسة رينج و آخرون (2007)، و هشام عبد الله .$(2008)$ 5. أظهرت در اسات وجود علاقة بين الشعور بالضغوط النفسية و انخفــاض مستوى جودة الحياة ومنها در اسة جافالا (2005).

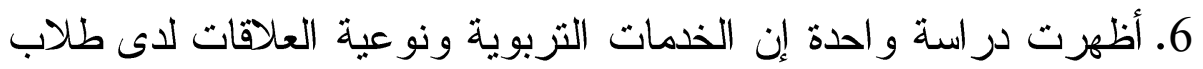

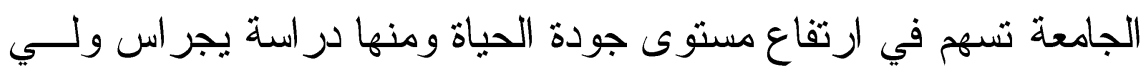
.(2008) 7. أن معظم الدر اسـات الخاصة بأساليب مو اجهة أحداث الحيــاة الضـــاغطة اهتمت باكتشاف هذه الأساليب لدى عينات مختلفة أو العلاقة بين أساليب

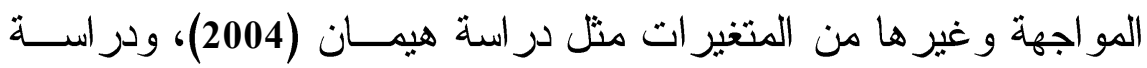

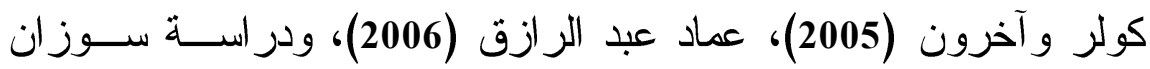

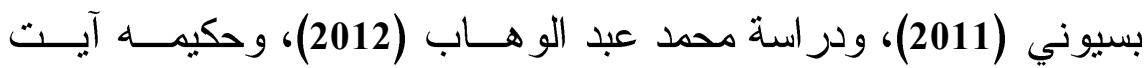


8. قلة الدر اسات التي اهتمت بأثز تقديم بر امج على تعديل أساليب مو اجهــة

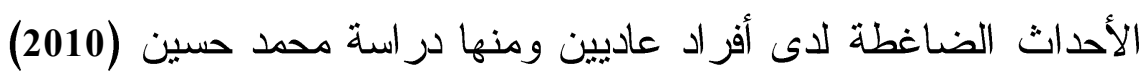

$$
\text { ونايف الحمد (2012)، و هناء محمد (2012). }
$$

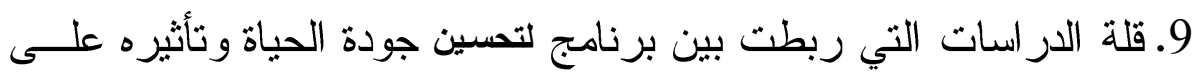

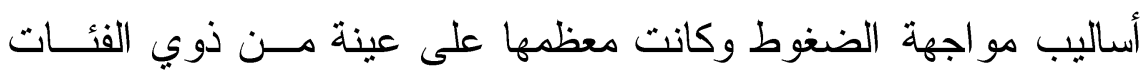

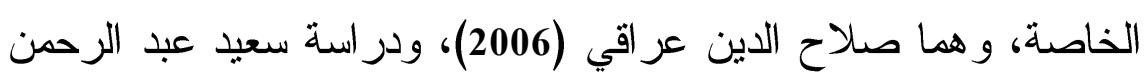
محمد (2011)، وكانت دراسة تحليلية أما در اسة مارك و آخرون (2002) فكانت على المرضى المصابين بنقص المناعة. وفي ضوء ما سبق يتبين إن مجال دراسة جودة الحياة لدى طلاب الجامعة

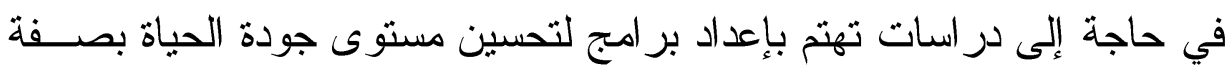
عامة ولدي الطالبات بصفة خاصة ، وتساهم في تتمية أساليب مو اجهة الأحداث الضاغطة، خاصة في ظل الظروف الر اهنة.

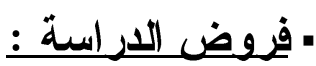

في ضوء الإطار النظري و البحوث و الدراسات السابقة تم اثـــقاق فـروض البحث.

1. يوجد فرق ذا دلالة إحصائية بين متوسطي رتب درجــات المجـــوعتين التجريبية و الضابطة في جودة الحياة بعد تطبيق البرنامج الإرشادي المقتر ح لصالح المجموعة التجريبية. 2. يوجد فرق ذا دلالة إحصائية بين متوسطي رتب درجــات المجمــوعتين

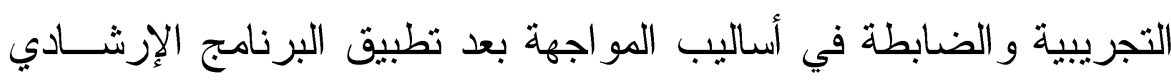
المقتر ح لصالح المجموعة التجريبية. 3. لا يوجد فرق ذا دلالة إحصائية بين متوسطي رتب درجات القياسين البعدي و التتبعي للمجموعة التجريبية في جودة الحياة. 
4. لا يو جد فرق ذا دلالة إحصائية بين متوسطي رتب درجات القياسين البعدي و التتبعي للمجمو عة التجريبية في أساليب المو اجهة.

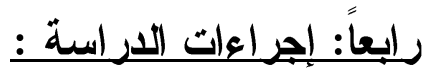
أ- منهج الار اسة:

اعتمدت الدر اسة الحالية على المنهج شبه التجريبي و التصميم المســتخدم

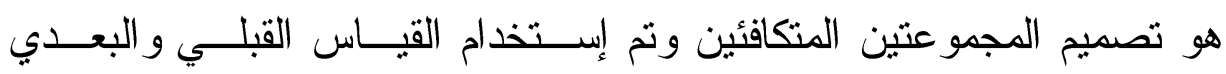

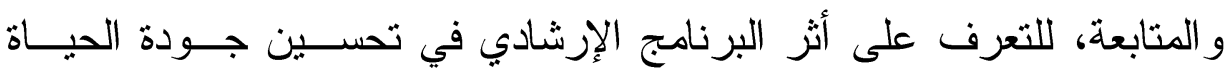
و أساليب مو اجهة أحداث الحياة الضاغطة لاعثى لإن طالبات الجامعة. ب- عينة الار اسةة: 1 1عينة الار اسة الأوليه:

تكونت عينة الدر اسة الأوليه من بين طالبات الجامعة وبلغ عــدهم (50) طالبة في كلية التربية بالفرقة الر ابعة ، ممن تنز اوح أعمار هن بين (19: 21)

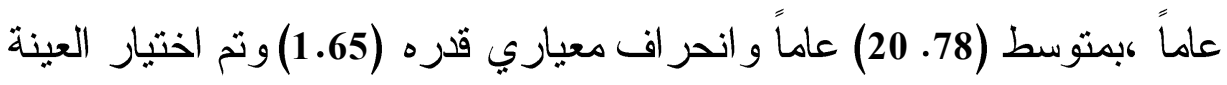

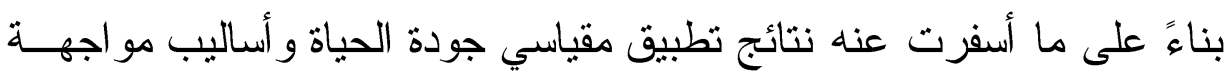

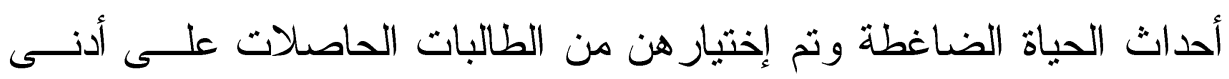

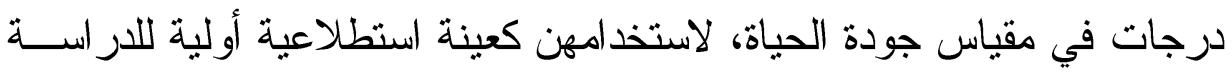

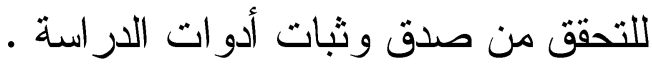

$$
\begin{aligned}
& \text { 2-عينة الار اسة الأساسية: }
\end{aligned}
$$

تم اثتقاق عينة الدر اسه الأساسية من بين طالبات الجامعة وبلغ عـددهن

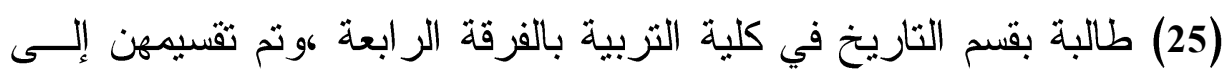

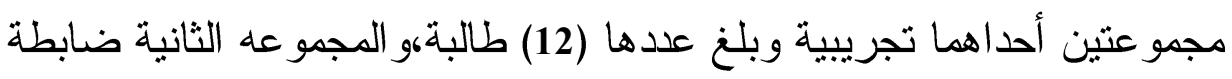

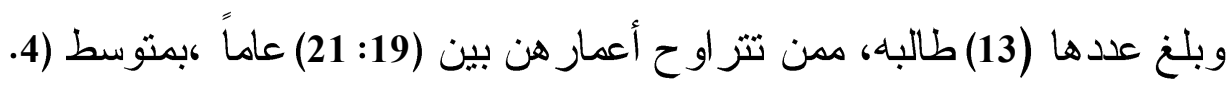

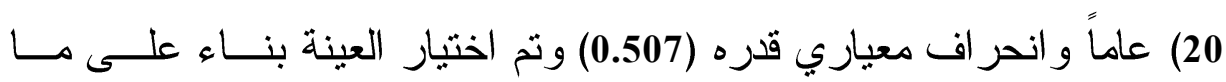
أسفرت عنه نتائج تطبيق مقياسي جودة الحياة وأساليب مواجهة أحداث الحياة 
الضاغطة وتم إختيار هن من الطالبات الحاصلات على أدنى درجات في مقياس

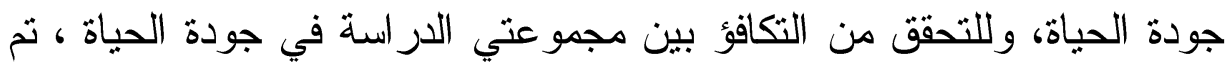

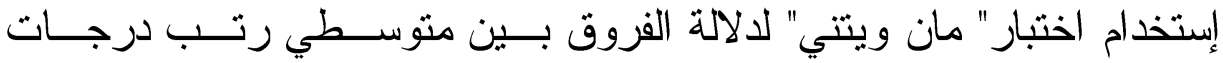
المجموعتين التجريبية و الضابطة في القياس القبلي لجودة الحياة ويتضح ذلك ملك

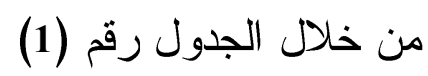

جدول (1): نتائج إختبار مان ويتتي لالالة الفروق بين متوسطي رتب درجات المجموعتين التجريبية والضابطة في القياس القبلي لجودة الحياة

\begin{tabular}{|c|c|c|c|c|}
\hline $\mathbf{Z}$ & $\mathbf{U}$ & مجموع الرتب & متوسط الرتب & المجموعة \\
\hline \multirow[t]{2}{*}{0,499} & \multirow[t]{2}{*}{35,00} & 91,00 & 10,11 & التجريبية \\
\hline & & 80,00 & 8,89 & الضابطة \\
\hline
\end{tabular}

ويتضح من الجدول السابق عدم وجود فروق ذات دلالة إحصــائية بــين

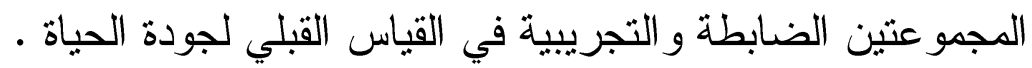
وللتحقق من تكافؤ مجموعتي الدر اسة في القياس القبلي لأساليب مو اجهـــة

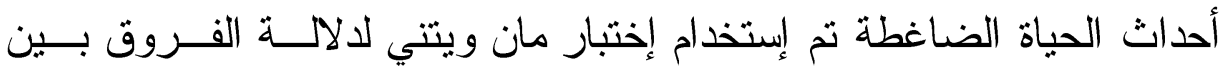
متوسطي رتب درجات المجموعتين التجريبية و الضابطة في القيــاس القبلــي

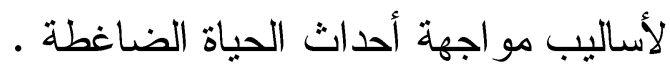
جدول (2): نتائج إختبار مان ويتني لدلالة الفروق بين متوسطي رتب درجات

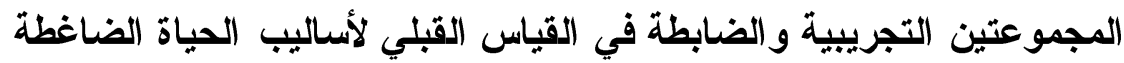

\begin{tabular}{|c|c|c|c|c|}
\hline $\mathbf{Z}$ & $\mathbf{U}$ & مجموع الرتب & متوسط الرتب & |المجموعة \\
\hline \multirow[t]{2}{*}{0,180} & \multirow[t]{2}{*}{ 38,50 } & $\mathbf{8 7 , 5 0}$ & 9,72 & |التجريبية \\
\hline & & 83,50 & 9,28 & |الضابطة \\
\hline
\end{tabular}

ويتضح من الجدول السابق عدم وجود فروق ذات دلالـــة إحصــائية بـين

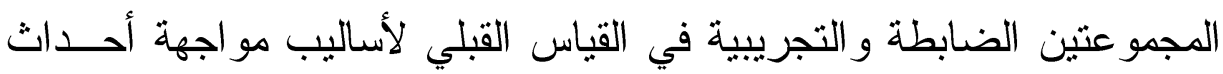
الحياة الضاغطة . (ج) أدوات الار اسـة: 


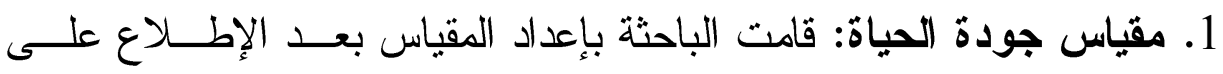

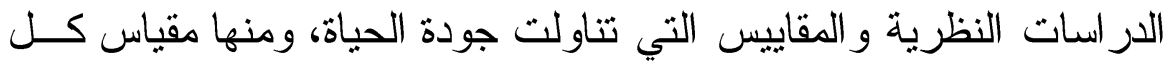
من حنان الجمال ونو ال شرقاوي (2008)، هند سليم (2008)، هشام عبد الله (2008)، عصام عبد العزيز (2008)، شاهر سليمان (2008) اعتدال حسانين (2009)، هانم مصطفى (2009)، (2009)، محمود منسي و علي كاظم (2010).

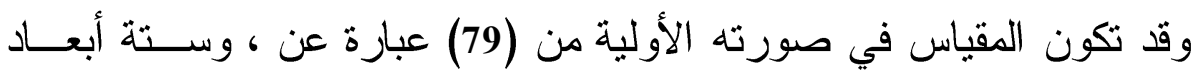

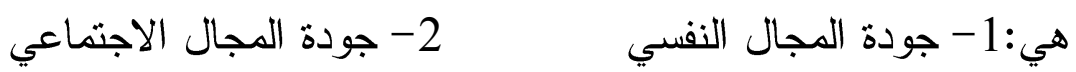

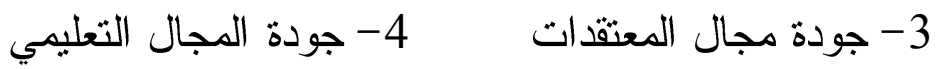

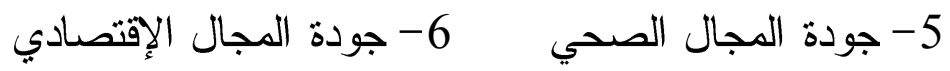
قامت الباحثة بعد ذلك بالتحقق من صدق وثبات المقياس على النحو التالي: أولاً: صدق المقياس: تم إستخدام الصدق المنطقي، و الصدق العاملي كالتالي: 1- الصدق المنطقي: نم عرض المقياس على خمسة من المتخصصين في علم

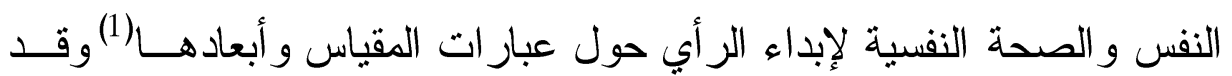
قامت الباحثة بحساب نسبة الإتفاق علي كل عبارة من عبار ات المقياس ، كما لإن قامت بحذف العبار ات التي كانت نسبة المو افقة عليها أقل من 80\%، وأسفرت النتيجة عن استبعاد خمس عبار ات فأصبح المقياس في صورته النهائية يتكون من (74) عبارة(20).

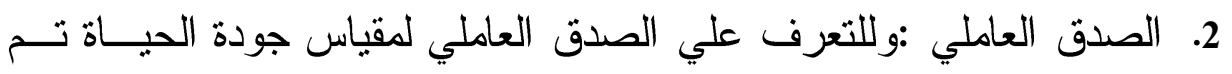
حساب المصفوفة الإرتباطية لعبارات المقياس،وقد اسفر التحليل العساملي 
لأبعاد المقياس عن وجود عاملين الأول بجذر كامن (3.20) ويفسر (53,49\%)

وتثبع عليه (76.)،و الثاني بجذر كامن (1,08)ويفسر (18,09\%) وتشبع عليه 91

- الإتساق الأخلي للمقياس: تم حساب معامل الارتباط بين العبار ات و الدرجة الكلية للبعد الذي تنتمي إليه وكانت قيم معاملات الارتباط كما يوضحها الجدول التالي:

جدول (3): معامل الإرتباط بين العبارات والارجة الكلية للبعد الفرعي لمقياس جودة الحياة

\begin{tabular}{|c|c|c|c|c|c|}
\hline 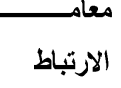 & العبار ات & الأبعاد & معامل الارتباط & العبار ات & الأبعاد \\
\hline$* * 0.584$ & 10 & \multirow{10}{*}{$\begin{array}{l}1 \\
: 3 \\
\frac{1}{3} \\
\overline{3} \\
\overline{3} \\
\frac{1}{3}\end{array}$} & $* 0.344$ & 1 & \multirow{13}{*}{ 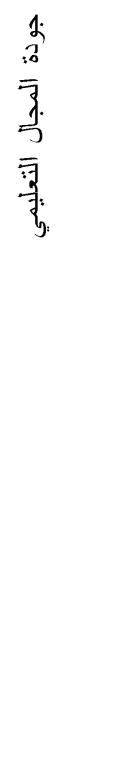 } \\
\hline$* 0.305$ & 16 & & $* * 0.598$ & 7 & \\
\hline$* * 0.545$ & 21 & & $* * 0.698$ & 13 & \\
\hline$* * 0.804$ & 27 & & $* * 0.499$ & 18 & \\
\hline$* * 0.640$ & 33 & & $* * 0.334$ & 24 & \\
\hline$* * 0.679$ & 39 & & $* 0.276$ & 30 & \\
\hline$* * 0.861$ & 45 & & $* 0.279$ & 36 & \\
\hline$* * 0.785$ & 51 & & $* * 0.737$ & 42 & \\
\hline$* * 0.831$ & 57 & & $* * 0.292$ & 48 & \\
\hline$* * 0.766$ & 63 & & $* * 0.737$ & 54 & \\
\hline$* * 0.490$ & 5 & \multirow{12}{*}{$\begin{array}{l}\frac{1}{3} \\
: 3 \\
\overline{3} \\
\overline{3} \\
\overline{3} \\
\overline{3}\end{array}$} & $* * 0.839$ & 60 & \\
\hline$* * 0.622$ & 11 & & $* * 0.282$ & 66 & \\
\hline$* * 0.474$ & 22 & & $* * 0.753$ & 74 & \\
\hline$* * 0.734$ & 28 & & $* * 0.744$ & 2 & \multirow{10}{*}{ 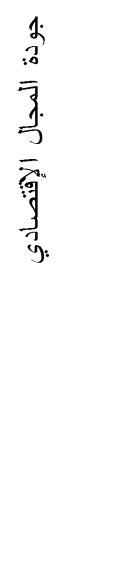 } \\
\hline$* * 0.392$ & 34 & & $* * 0.525$ & 8 & \\
\hline$* * 0.602$ & 40 & & $* * 0.753$ & 14 & \\
\hline$* * 0.388$ & 46 & & $* * 0.659$ & 19 & \\
\hline$* * 0.434$ & 52 & & $* * 0.783$ & 25 & \\
\hline$* * 0.404$ & 58 & & $* * 0.484$ & 31 & \\
\hline$* * 0.349$ & 64 & & $* * 0.501$ & 37 & \\
\hline$* * 0.808$ & 68 & & $* * 0.516$ & 43 & \\
\hline$* * 0.744$ & 69 & & $* * 0.831$ & 49 & \\
\hline$* * 0.693$ & 70 & $つ$ & $* * 0.764$ & 55 & \\
\hline
\end{tabular}

doi : $10.12816 / 0001050$ 
مجلة الدراسات التربوية و الاسانية ـ كلية التربية - جامعة دمنهور - المجلد الخامس العدد (1) لسنة 2013

\begin{tabular}{|c|c|c|c|c|c|}
\hline 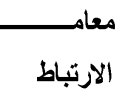 & العبار ات & الأبعاد & معامل الارتباط & العبار ات & الأبعاد \\
\hline$* * 0.340$ & 6 & & $* * 0.880$ & 61 & \\
\hline$* 0.283$ & 12 & & $* * 0.880$ & 67 & \\
\hline$* 0.281$ & 17 & & $* 0.521$ & 3 & 1 \\
\hline$* * 0.467$ & 23 & & $* * 0.695$ & 9 & $\overline{3}$ \\
\hline$* * 0.433$ & 29 & & $* * 0.720$ & 15 & \\
\hline$* * 0.508$ & 35 & & $* * 0.579$ & 20 & y. \\
\hline$* * 0.514$ & 41 & & $* * 0.481$ & 26 & \\
\hline$* * 0.594$ & 47 & & *0.291 & 32 & \\
\hline$* * 0.611$ & 53 & & $* * 0.293$ & 38 & \\
\hline$* * 0.416$ & 59 & & $* * 0.595$ & 44 & \\
\hline$* * 0.700$ & 65 & & $* * 0.475$ & 50 & \\
\hline$* * 0.505$ & 71 & & $* * 0.410$ & 56 & \\
\hline$* * 0.348$ & 72 & & $* 0.296$ & 62 & \\
\hline$* * 0.426$ & 73 & & $* * 0.627$ & 4 & \\
\hline
\end{tabular}

يتضح من الجدول السابق أن جميع معاملات ارتباط العبار ات بالدرجــة

الكلية للبعد الذي تتنمي إليه دالة إحصائياً عند مستوى 0.01 فيما عدا العبار ات أرقام (1، 12، 16، 17، 30، 32، 36، 62) كانت دالة عند مستوى 0.05 وبــذلك

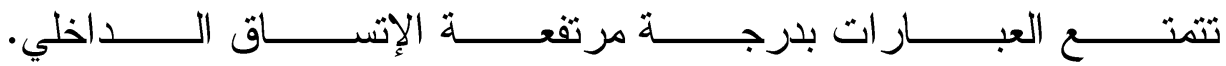

\begin{tabular}{|c|c|c|c|}
\hline \multirow{2}{*}{ معامل ثبات ألفا كرونباخ } & \multicolumn{2}{|c|}{ معامل ثبات التجزئة النصفية } & \multirow{2}{*}{ الأبعاد } \\
\hline & | جيتمان & سبيرمان -بر اون & \\
\hline 0.676 & 0.823 & 0.841 & 1- جودة المجال التعليمي \\
\hline 0.863 & 0.828 & 0.829 & 2- جودة المجال الإقتصادي \\
\hline 0.603 & 0.631 & 0.643 & 3- جودة المجال الصحي \\
\hline 0.881 & 0.843 & 0.856 & 4- جودة مجال المعثقدات \\
\hline 0.696 & 0.689 & 0.715 & 5- جودة المجال النفسي \\
\hline 0.625 & 0.551 & 0.542 & 6 -جودة المجال الاجتماعي \\
\hline 0.877 & 0.816 & 0.850 & الارجة الكلية \\
\hline
\end{tabular}

كما قامت الباحثة بحساب معاملات ارتباط الأبعاد الفرعيــة بالدرجـــة الكليــة للمقياس وكانت على النحو التالي:0.787 جودة المجال التعليمي، 0.308 جـودة 


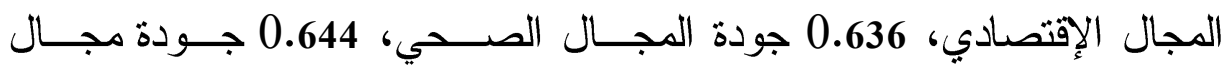
المعتقدات، 0.811 جودة المجال النفسي 0.791 جودة المجال الإجتماعي، وكلها

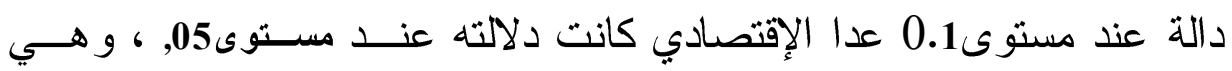
معاملات إرتباط مرتفعة. ثانياً : حساب ثبات المقياس :

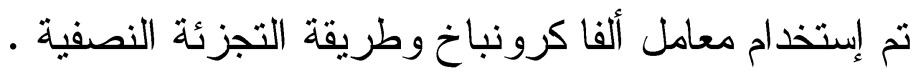
- معامل ألفا كرونباخ وطريقة التجزئة النصفية: قامت الباحثة بحساب ثبات المقياس بطريقة التجزئة النصفية لعبار ات كل

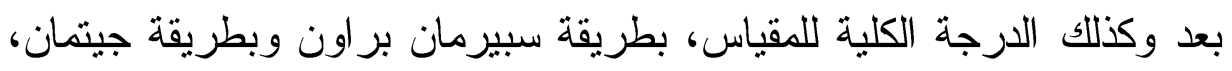

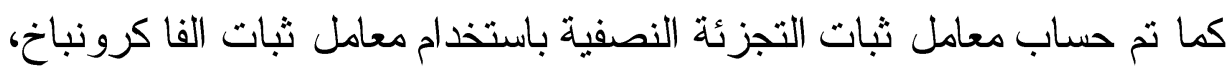
كما يتضح من الجدول التالي: جدول (4) معامل ثبات التجزئة النصفية لأبعادمقياس جودة الحياة

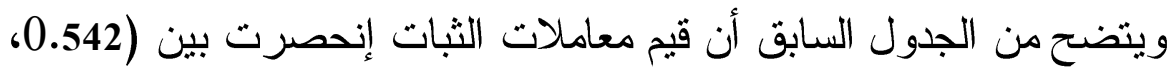

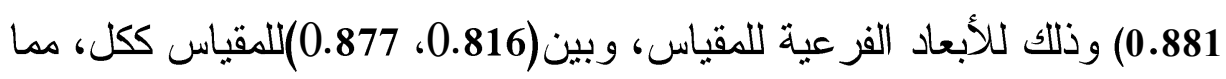
يشير إلى تمتع المقياس بدرجة مرتفعة من الثبات. - مقياس أساليب مواجهة أحداث الحياة الضاغطة:

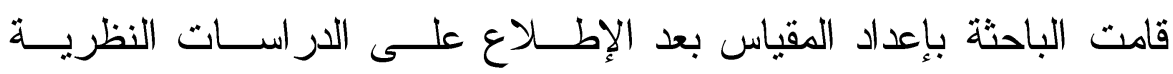

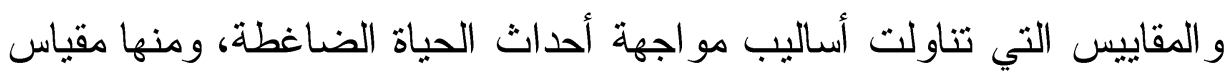

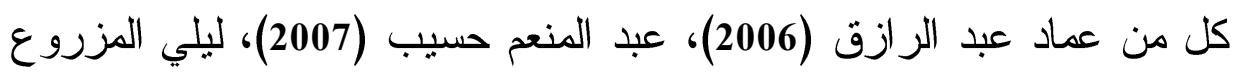

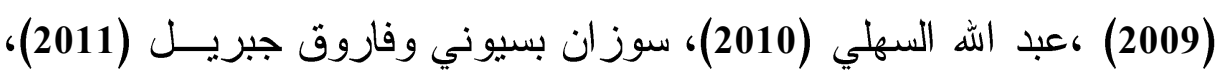

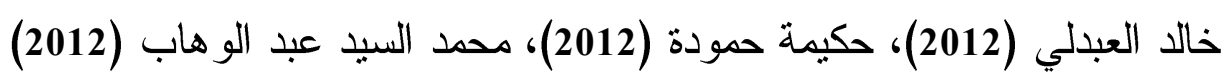
وقد تكون المقياس من (66) عبارة وخمسة أبعاد هي: (2012)،

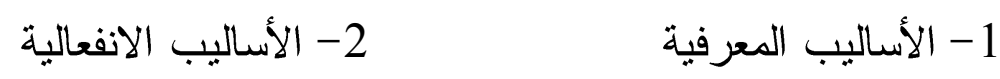
3- الأساليب الفسيولوجية ( البدنيه ) - الأساليب الاجتماعية 


\section{5- الأساليب الدينية}

وقامت الباحثة بالتحقق من صدق وثبات المقياس على النحو التالي: أولاً: صدق المقياس:

تم استخدام الصدق المنطقي، و الصدق العاملي ، كالتالي:

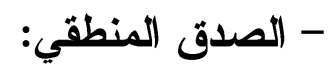

تم عرض المقياس على خمسة من المتخصصين في علم النفس والصحة

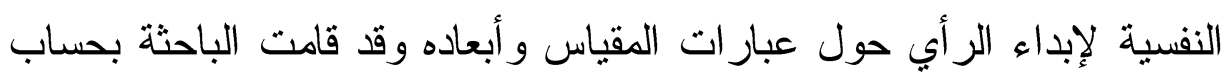

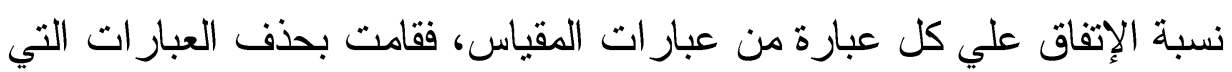

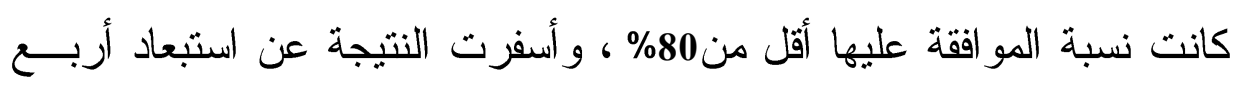

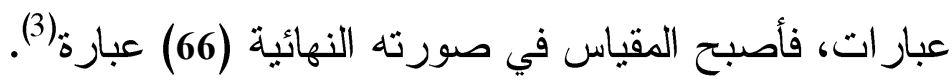
- الصدق العاملي : الصدات

اسفر الصدق العاملي عن تشبع الأبعاد علي عامل ع بجذر كـامن(56.231)

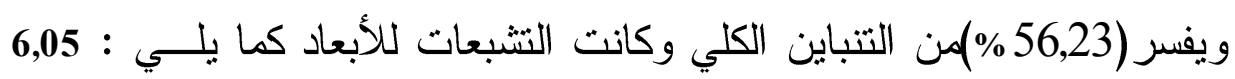

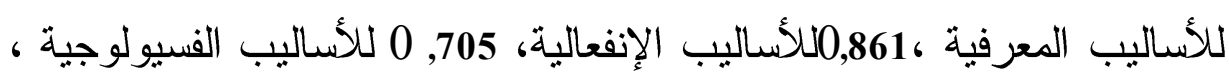
0,719 للأساليب الإجتماعية ، 0,831 للأساليب الدينية .

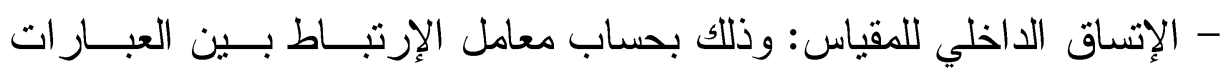

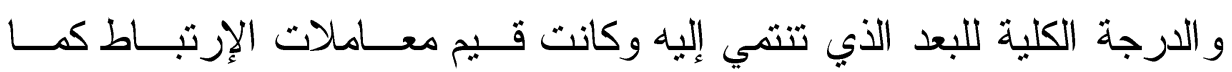

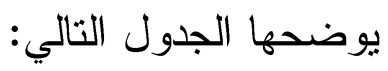


جدول (5) معامل الإرتباط بين العبارات والارجة العليةللبع الفرعي لمقياس أساليب

مواجهة أحداث الحياة الضاغطه

\begin{tabular}{|c|c|c|c|c|c|c|c|c|}
\hline معامـــــــــل & العبارات & الأبعاد & معامــــــل & العبارات & الأبعاد & معامـــــــل & العبارات & الأبعاد \\
\hline$* * 0.342$ & 45 & & $* * 0.397$ & 23 & & $* * 0.548$ & 1 & \multirow{11}{*}{$\begin{array}{l}\overline{3} \\
\overline{3} \\
\overline{3} \\
\overline{3} \\
.97 \\
.9\end{array}$} \\
\hline$* * 0.400$ & 46 & & $* 0.304$ & 24 & & $* * 0.863$ & 2 & \\
\hline$* * 0.708$ & 47 & & $* * 0.452$ & 25 & & $* * 0.631$ & 3 & \\
\hline$* * 0.679$ & 48 & \multirow{6}{*}{ 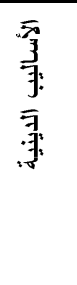 } & $* * 0.599$ & 26 & \multirow{15}{*}{ 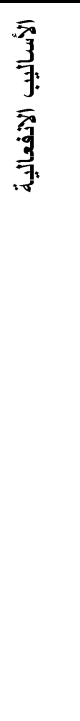 } & $* * 0.579$ & 4 & \\
\hline$* * 0.368$ & 49 & & $* * 0.550$ & 27 & & $* * 0.736$ & 5 & \\
\hline$* * 0.708$ & 50 & & $* * 0.458$ & 28 & & $* 0.774$ & 6 & \\
\hline$* * 0.520$ & 51 & & $* * 0.671$ & 29 & & $* * 0.433$ & 7 & \\
\hline$* * 0.673$ & 52 & & $* * 0.457$ & 30 & & $* * 0.422$ & 8 & \\
\hline$* * 0.482$ & 53 & & $* * 0.306$ & 31 & & $* * 0.499$ & 9 & \\
\hline$* * 0.304$ & 54 & \multirow{13}{*}{ 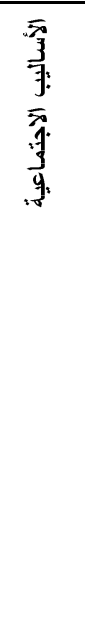 } & $* * 0.660$ & 32 & & $* * 0.474$ & 10 & \\
\hline *0.271 & 55 & & $* * 0.424$ & 33 & & $* * 0.419$ & 11 & \\
\hline$* * 0.777$ & 56 & & $* 0.304$ & 34 & & $* * 0.442$ & 12 & \multirow{11}{*}{ 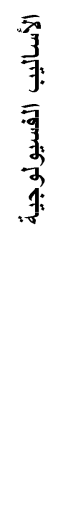 } \\
\hline$* * 0.539$ & 57 & & $* * 0.833$ & 35 & & $* * 0.337$ & 13 & \\
\hline$* * 0.646$ & 58 & & $* * 0.770$ & 36 & & $* * 0.564$ & 14 & \\
\hline$* * 0.691$ & 59 & & $* * 0.642$ & 37 & & $* * 0.604$ & 15 & \\
\hline$* * 0.685$ & 60 & & $* * 0.772$ & 38 & & $* * 0.567$ & 16 & \\
\hline ** 0.544 & 61 & & ** 0.401 & 39 & & $* * 0.508$ & 17 & \\
\hline$* * 0.447$ & 62 & & $* * 0.365$ & 40 & & *0.259 & 18 & \\
\hline$* * 0.572$ & 63 & & $* * 0.698$ & 41 & & $* * 0.528$ & 19 & \\
\hline$* * 0.270$ & 64 & & $* * 0.573$ & 42 & & $* * 0.543$ & 20 & \\
\hline$* * 0.811$ & 65 & & $* * 0.335$ & 43 & & $* * 0.803$ & 21 & \\
\hline * 0.645 & 66 & & * 0.637 & 44 & & * 0.605 & 22 & \\
\hline
\end{tabular}

يتضح من الجدول السابق أن جميع معاملات ارتباط العبــار ات بالدرجــة الكلية للبعد الذي تتنمي إليه دالة إحصائياً عند مستوى0.01 فيما عدا العبار ات أرقام (18، 24، 34، 55)كانت دالة عند مستوى (0.05) مما بعني تمتع العبار ات بدرجة مرتفعة من الاتساق الداخلي في قياس أساليب مواجهة أحــداث الحيــاة الضاغطة كما قامث الباحثة بحساب معاملات ارتباط الأبعاد الفرعية بالدرجـة الكلية للمقياس وكانت على النحو التالي: 0.648 للأساليب المعرفيـة، 0.841 للأساليب الانفعالية،0.743 للأساليب الفسيولوجية،0.670 للأساليب الاجتماعية، 0.817 للأساليب الدينية، وكلها دالة عند مستوى 0.01. doi : $10.12816 / 0001050$ 
ثانياً : حساب ثبات المقياس :

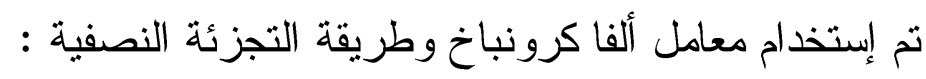
- معامل ألفا كرونباخ، وطريقة التجزئة النصفية: تم حساب ثبات مقياس أساليب مو اجهة الأحداث الضاغطة بطريقة التجزئة النصفية، وصحح معامل الثبات بطريقة سبيرمان بر اون وبطريقة جيتهــان،

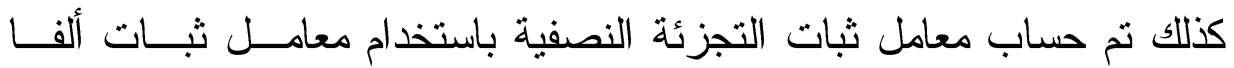
كرونباخ، كما يتضح من الجدول التالي: جدول (6):معاملات ثبات التجزئة النصفية لأبعاد مقياس أساليب مواجهة أحاث الحياث الحياة الضاغطه

\begin{tabular}{|c|c|c|c|}
\hline \multirow{2}{*}{ كرونباخ ثبات ألفا } & \multicolumn{2}{|c|}{ ثبات التجزئة النصفية } & \\
\hline & جيتمان & سبيرمان - براون & الأبعاد \\
\hline 0.720 & 0.586 & 0.606 & الأساليب المعرفية \\
\hline 0.732 & 0.728 & 0.731 & الأسـاليب الإنفعالية \\
\hline 0.831 & 0.909 & 0.917 & الأساليب الفسيولوجية \\
\hline 0.787 & 0.654 & 0.657 & الأساليب الإجتماعية \\
\hline 0.747 & 0.631 & 0.636 & الأساليب الاينية \\
\hline 0.905 & 0.755 & 0.756 & الارجة الكلية \\
\hline
\end{tabular}

يتضح من الجدول السابق أن قيم معاملات الثبات انحصرت بين (0.586،

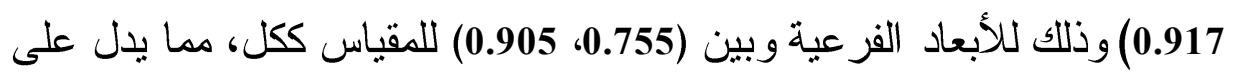
تمتع المقياس بجميع أبعاده بلرجة عالية من الثبات. 3 - البرنامج الإرشادي المقترح:

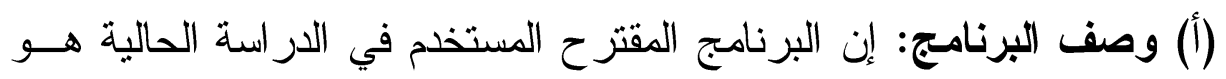

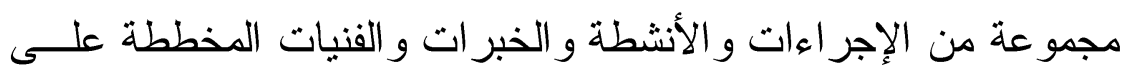

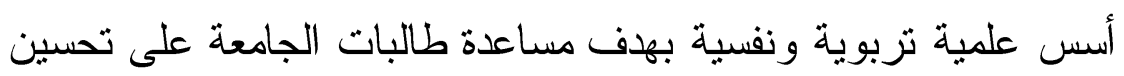
إدر اكهم لجودة الحياة من خلال مجمو عات جلسات تقدم في فترة زمنية 
(ب) أهداف البرنامـج: الهذف الأساسي هو تحسين إدر الك جودة الحيــاة لــدى طالبات الجامعة.

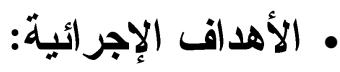

1. إكساب الطالبة مهار ات وطرق تساعدها في تحسين إدر اكها لجودة الحيــاة

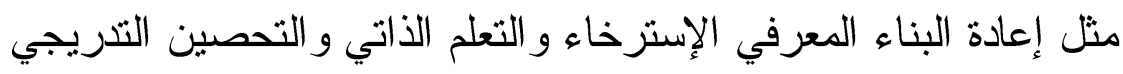
2. تتمية تقدير الذات لدى الطالبات.

3. إكساب الطالبة مهار ات مو اجهة أحداث الحياة الضاغطة.

4. إكساب الطالبة مهارة استخدام اسلوب حل المشكلات. 5. التعرف و التذريب على بعض الفنيات التي تسهم في توكيد الذات. 6. تتمية مهارة إدارة الانفعالات.

7. إكساب الطالبة مهارة التو اصل الفعال مع الآخرين. 8. إكساب الطالبة مهارة إدارة الوقت.

9. تزويد الطالبات بمعلومات ومعارف تقيد في تغييــر ســلوكياتهن الســلبية وممارسة سلوكيات صحية.

10 ـ إكساب الطالبة مهارة التخطيط للمستقبل. 11. إدر الك الأفكار اللاعقلانية و استبدالها بأفكار عقلانية. 12. تعزيز السلوك الإيجابي المرغوب. (ج) الأساس النظري للبرنامـج المقترح: استخدت الباحثة أســلوب الإرشــاد

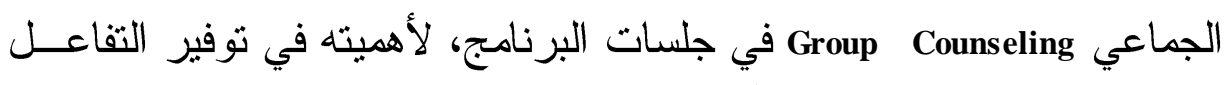

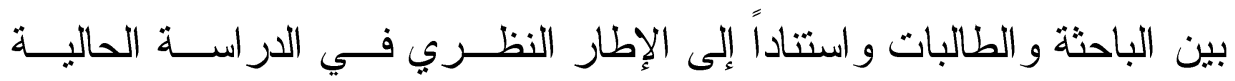

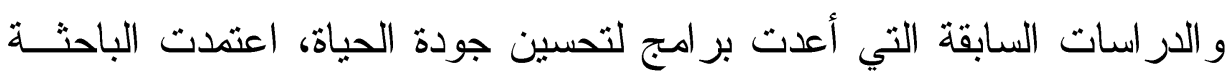

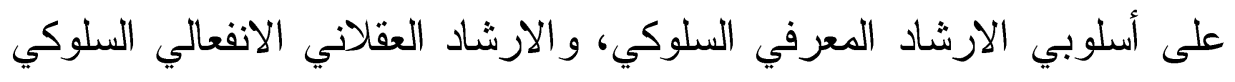

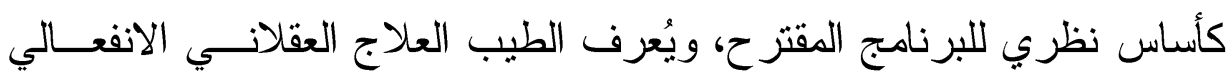

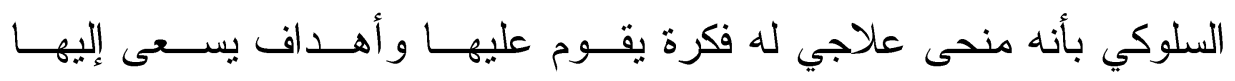




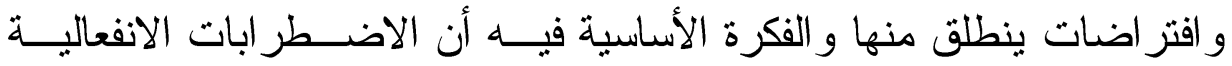
و النفسية تعود بدرجة كبيرة نتيجة التقكير بطريقة غير منطقية وغير عقلانية.

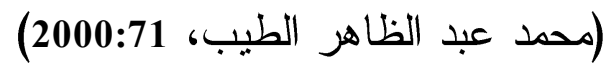
ويشير كوري Corey أن هدف العلاج الجماعي في نظريـــة الإرشــاد

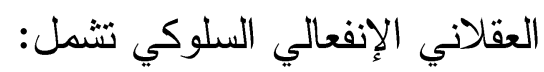

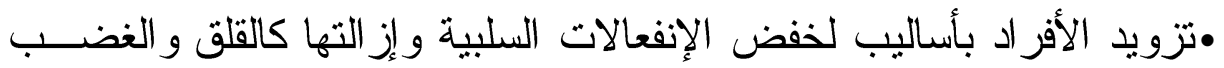
و الإحباط، وذللك عن طريق مراقبة الألفاظ و الأحاديث الذاتية، وتغيير

قيمهم ومعتقداتهم اللاعقلانية .

• تطوير خصائص عقلية و إنفعالية صحية للفرد منها التوجيه الــذاتي و إدارة الوقت و إدارة الإنفعالات و المرونة وقبول الذات غير المشروط وتقبل عدم الكمال.

ويعد "بيك" Beck وهو صاحب نظرية وأسلوب العلاج السلوكي المعرفي وتعدد

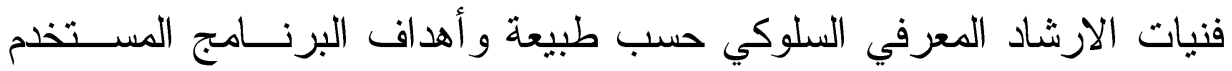

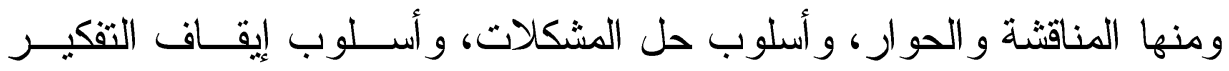
و الإرشاد العقلي العاطفي، و الضبط الذاتي، و الاســترخاء، و التعزيـز ، و وآداء

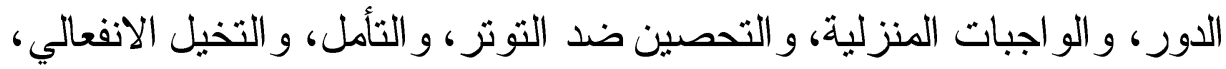
و الجدل المباشر، و التعريض وصرف الانتباه، و الاكتثاف الموجه.(آرون بيك

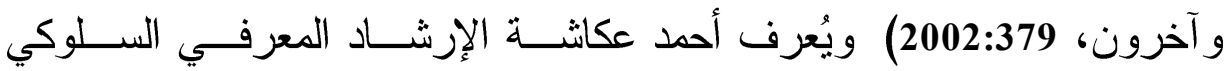
Cognitive - Behavioral Counseling بأنه إرشاد يهنم ويركز على دور الأفكار و المعتقدات و المعلومات في انفعالاتتا

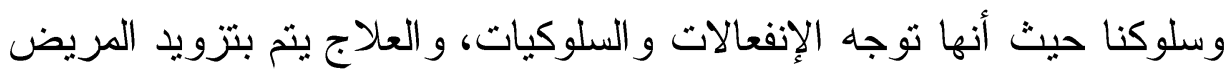

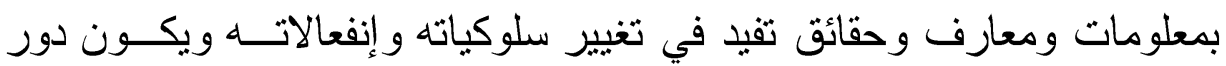

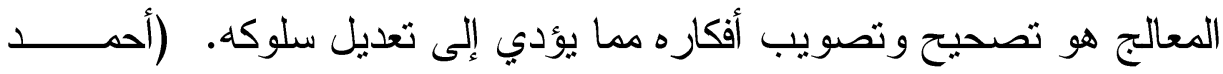
عكاشة، 2003 : 265 
ويشير عطاف أبو غالي (2011) إلى أن الإرشاد السلوكي المعرفي اتجاهاً حديثًا

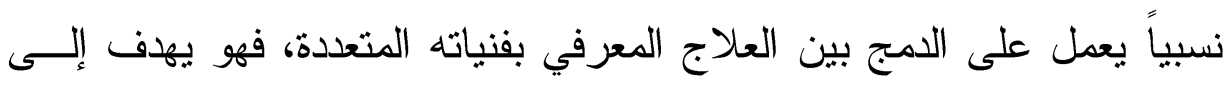

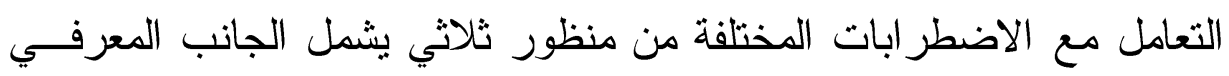

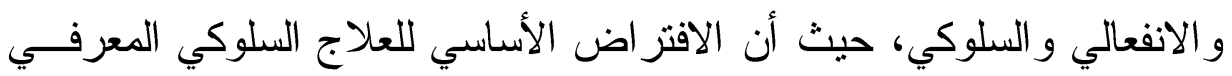

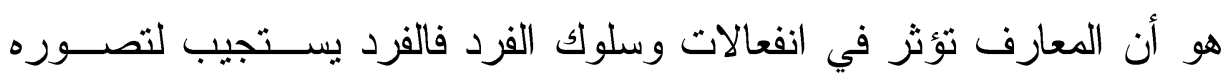

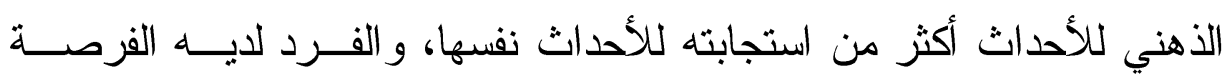
للتخلص من سوء التكيف المعرفي، الذي يؤدي بدوره إلى سوء التكيف بصفة لهن

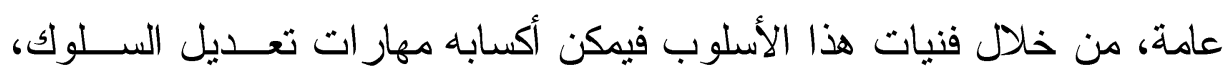

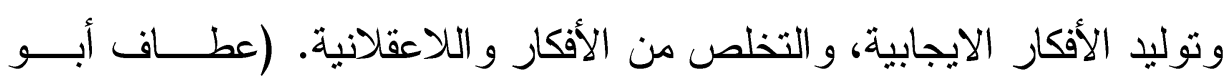

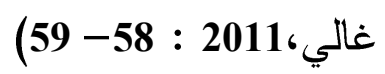

Rational ويُعد ألبرت أليس صاحب نظرية وأسلوب الإرشاد العقلاني الانفعالي

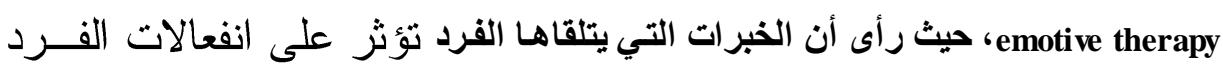

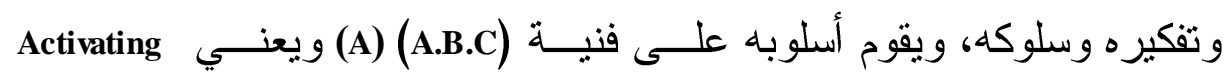
Experience

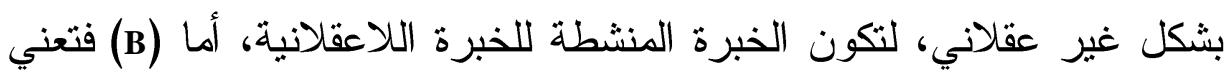
Belief system ويقصد بها نظام معتقدات لاعقلانيه مدمر للذات، و هي المعتقدات اللاعقلانية التي تعمي الفرد، أما Consequence (c) فتعني النتيجة الإنفعالية

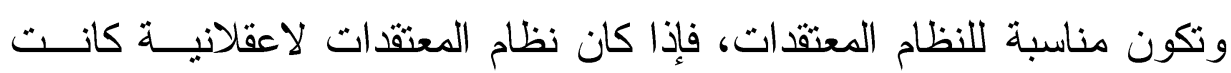
النتيجة إضطر اب إنفعالي وخلل سلوكي.(مدحت عبد المحسن الفقي، • أسباب فعالية الإرشاد المعرفي السلوكي: أفعالي وخلئ

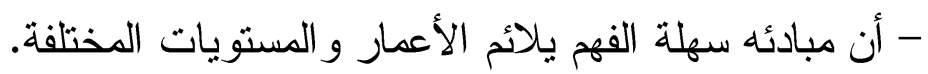
- لا يستغرق وقت طويل. - يدرب فيه الأفر اد على مهار ات حياتية مهمة، وكذلك على التحكم الذاتي

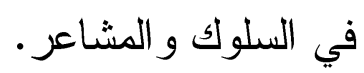


- يساعد الأفر اد على التعامل مع ما يمكن تغييرهوتقبل ما لا يمكن تغييره.

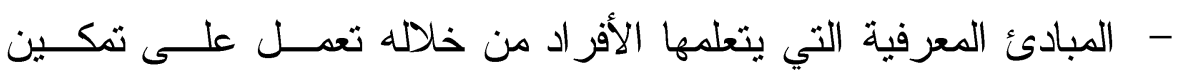
الثباب من التعامل مع المخاوف الحالية و المشكلات المستقبلية.

(Corey ، G. ، 2008 :365)

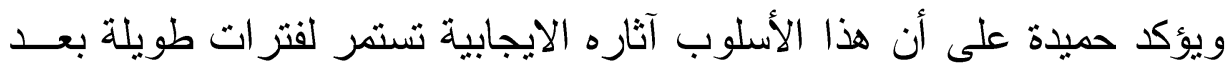

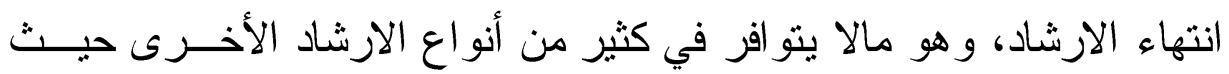

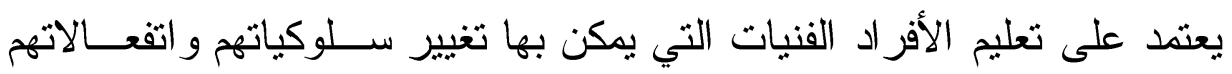

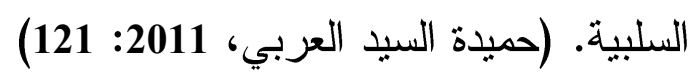
(1) (القنيات المستخدمة في البرنامج: 1) المحاضرة: هي أسلوب يهذف إلى تزويد الأفر اد بمعلومات ومعارف بهن بهدف إعادة البناء المعرفي.

2) المناقثة: وتتمثل هذه الفنية في إتاحة الفرصة لنبادل الخبرات و المهارات

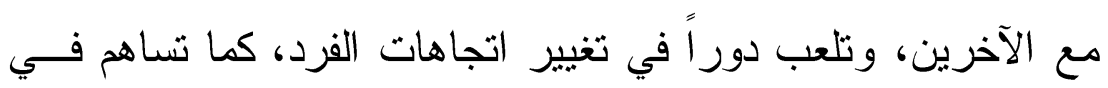
إعادة البناء المعرفي، وتدريب الأفر اد على التو اصل ونل و التفاعل.

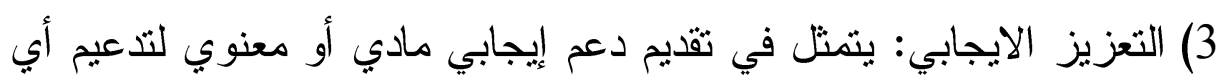

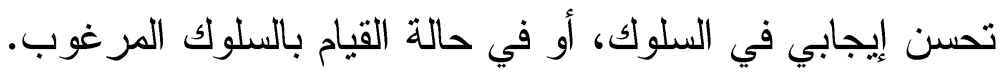

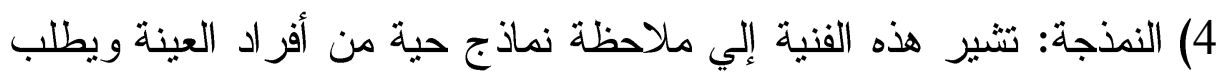

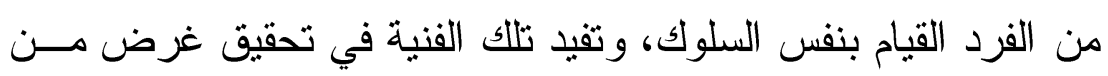
اثثين اما اكساب الفرد سلوك جديد، أو تعديل السلوك.

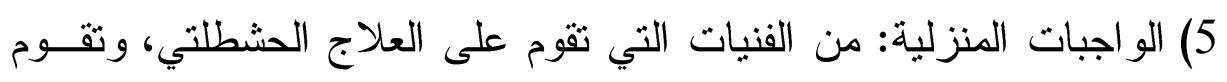
على مجموعة من المهار ات و الأنماط السلوكية في صورة تعلى تعيينات يتم

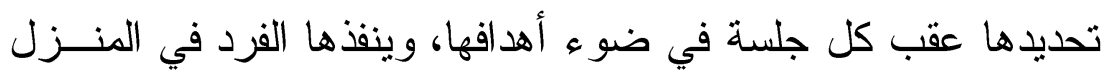
و هي تبدأ من البسيط إلى المعقد ومن المعارف إلى الأفعال. 
6) التحصين التدريجي: ويقصد به التخلص التدريجي من السلوك المضطرب

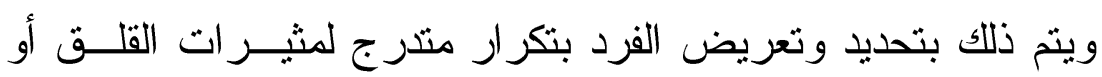
الاضطر اب لديه و هو في حالة استرخاء، ويستمر التعرض المتكــردر

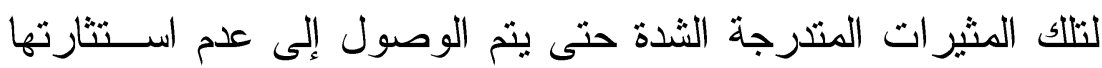

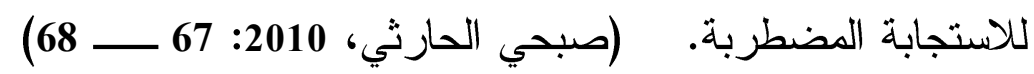

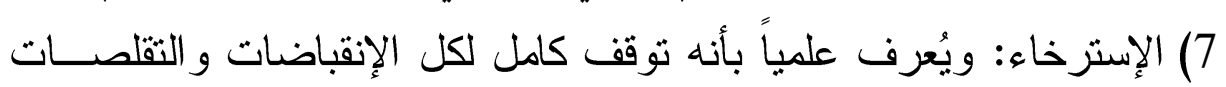

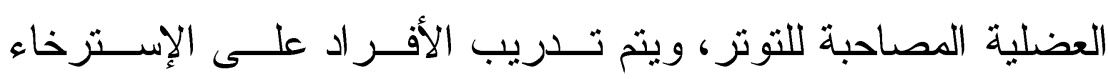

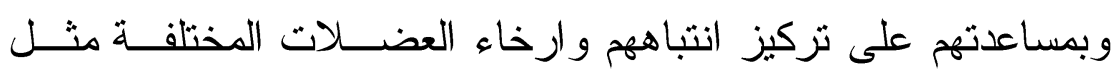

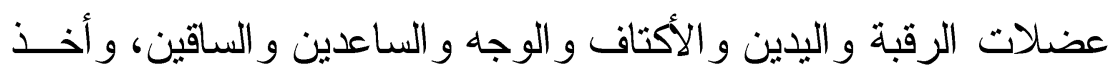

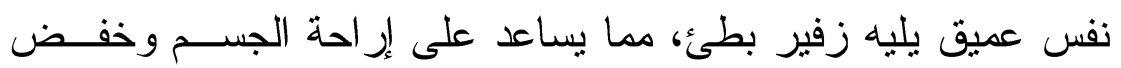

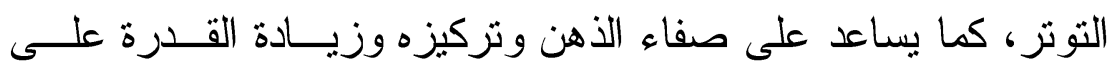
التحكم في عمليات التفكير وبتنمية الإنتباه.(ديفيد فونتانا، 1994: 150 ـ ـ

8) التعليم الذاتي: ويتضمن التعرف على الأفكار و التعبيرات الذاتية الســلبية المرتبطة بالضغوط و التي تسبب الضيق للفرد، ومساعدته على تعديل

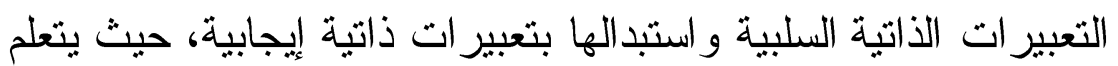

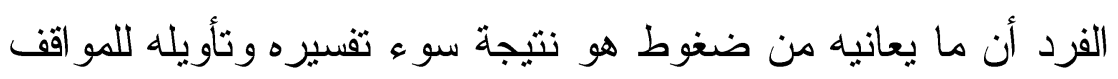
التي يتعرض إليها، وأيضاً نتيجة لأحاديث الذات السلبية لديه.

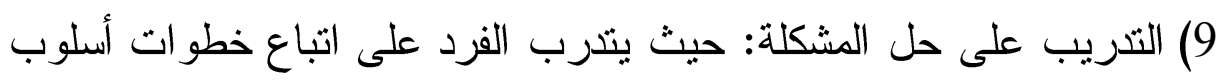

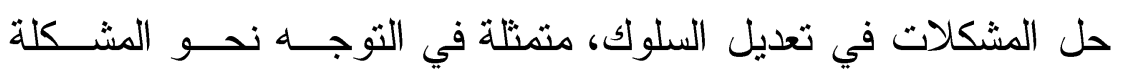

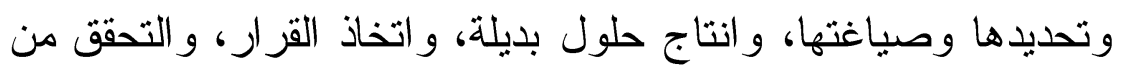

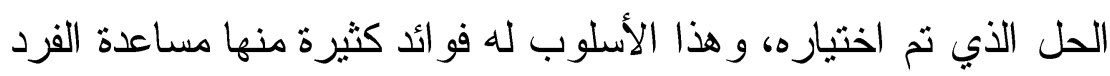
على إدر الك مشكلته، ثم التركيز على تقديم الحلول الممكنة المتنو عة لحل المشكلة وتقييمها. ( وحيد كامل، 2005 : 584-590 ) 
10) إعادة البناء المعرفي: تتضمن الفنية إعادة تقييم رؤية الفرد غير الواقعية

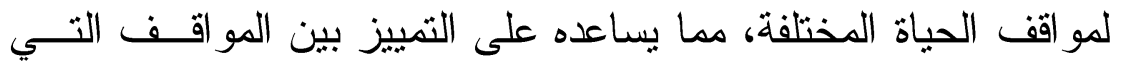

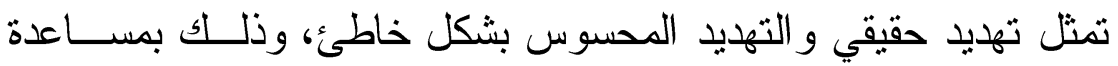

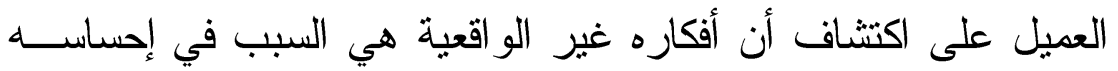
بشدة الضغط وليست الأحداث نفسها مما ينمي قدرة الفرد على التفكير العقلاني.( وحيد كامل، 2005: 584) ، (عطاف أبو غالي، 2011: 59 - 60بكة )

\section{هـ ) محتوى البرنامج:}

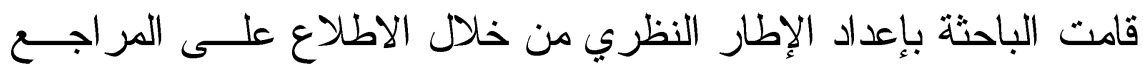

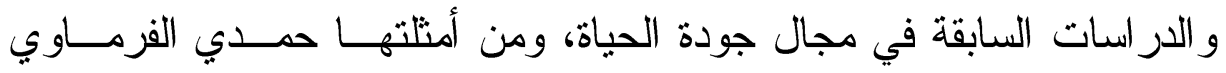

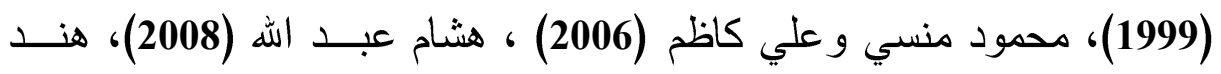
سليم(2008) عبد الحميد (2009)، زينب شقير (2010)، محمد أبـو راسـيـين (2012)، يتكون البرنامج المقترح من (14) جلسة مدة كل جلسة (60) دقيقــة

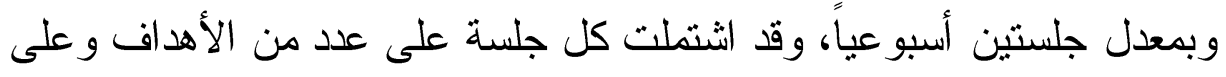

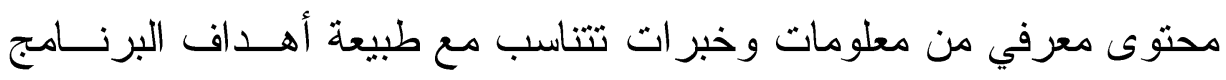

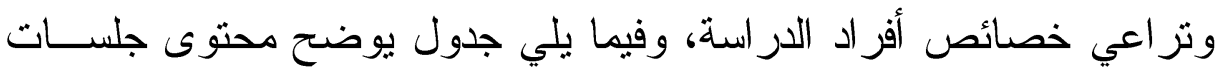
البرنامج جدول (7): جلسات البرنامج المقترح لتحسين جودة الحياة لاى طالبات الجامعة

\begin{tabular}{|c|c|c|c|}
\hline المستخدمة الفيات & محتوى الجلسة & أهداف الجلسة & رقم \\
\hline المناقشة المحرة & 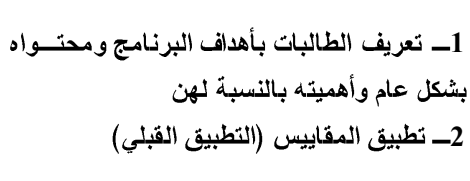 & 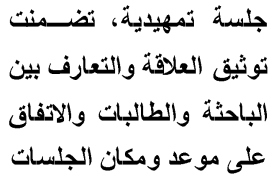 & 1 \\
\hline 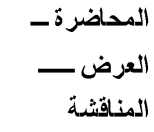 & 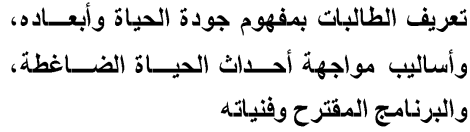 & التعريف بمفاهيم البرنـــامج & 2 \\
\hline مـاقثشة & 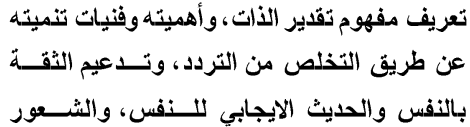 & تنمية تقدير الذات & 3 \\
\hline
\end{tabular}




\begin{tabular}{|c|c|c|c|}
\hline المستخدمة & محتوى الجلسة & أهداف الجلسة & رقمث \\
\hline العـادة البنــــاء & وبالأمسان، وتحمل المسئولية، والأستعداد للمواقق، & & \\
\hline 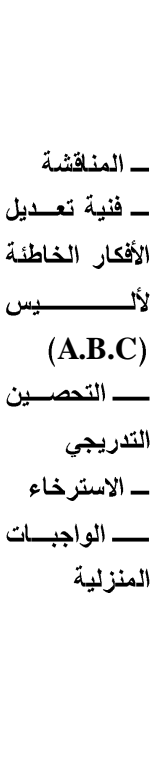 & 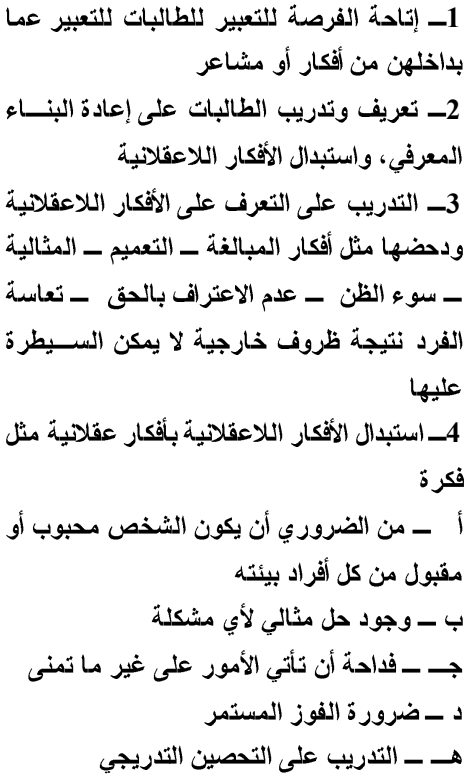 & 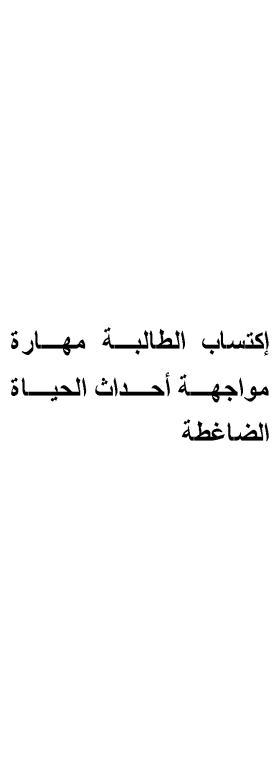 & 4 \\
\hline 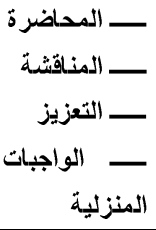 & تعريف الطالبات بأسلوب حل المشكلات وخطواته، & أسلوب حل المشكلاب الطــة مهـــارة & 5 \\
\hline 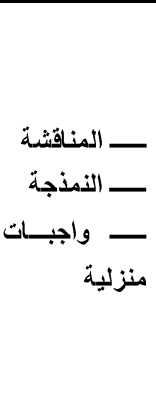 & 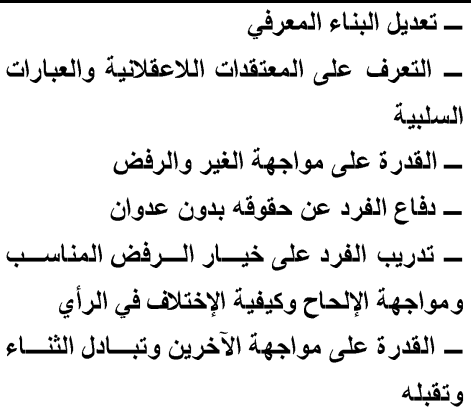 & تنمية توكيد الذات & 6 \\
\hline
\end{tabular}


مجلة الدراسات التزبوية و الاسانية ـ كلية التربية - جامعة دمنهور - المجلد الخامس العدد (1) لسنة 2013

\begin{tabular}{|c|c|c|c|}
\hline المستخدمة & محتوى الجلسة & أهداف الجلسة & رقمث \\
\hline — - ـ- النمذجة المحاضرة & 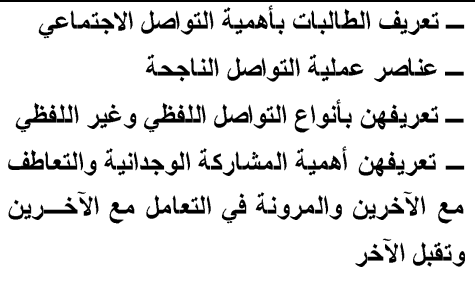 & الكتــاب الطالبـــة مهـــارة & 7 \\
\hline 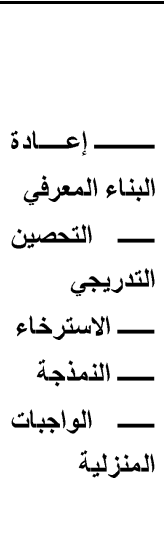 & 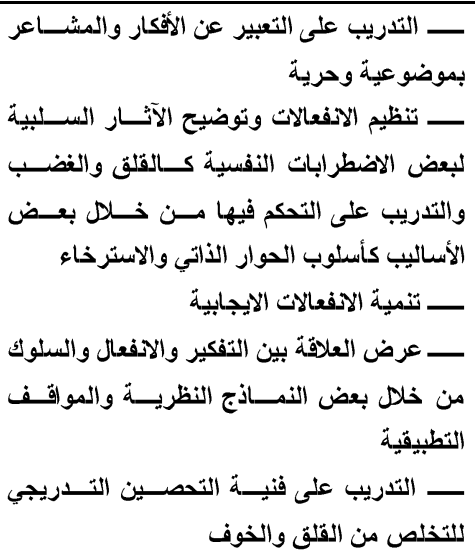 & الإكتساب الطالبة مهارة إدارة & 8 \\
\hline & 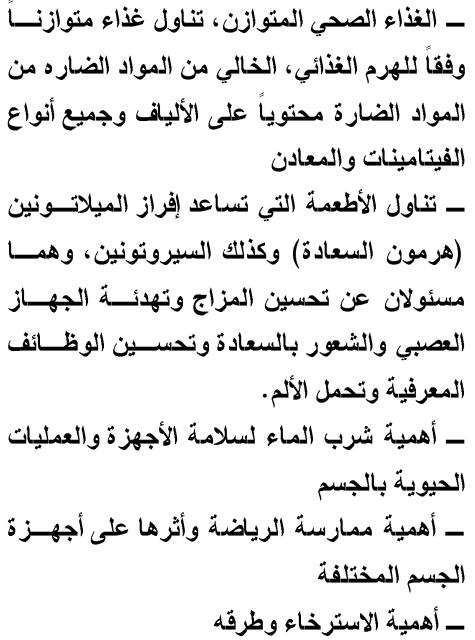 & 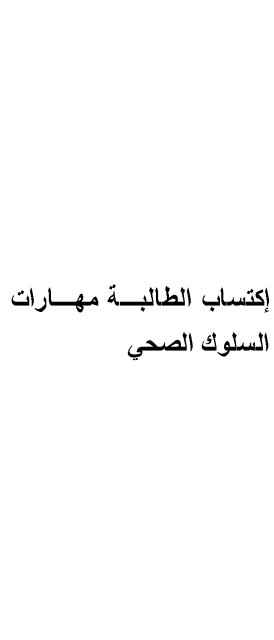 & 9 \\
\hline
\end{tabular}




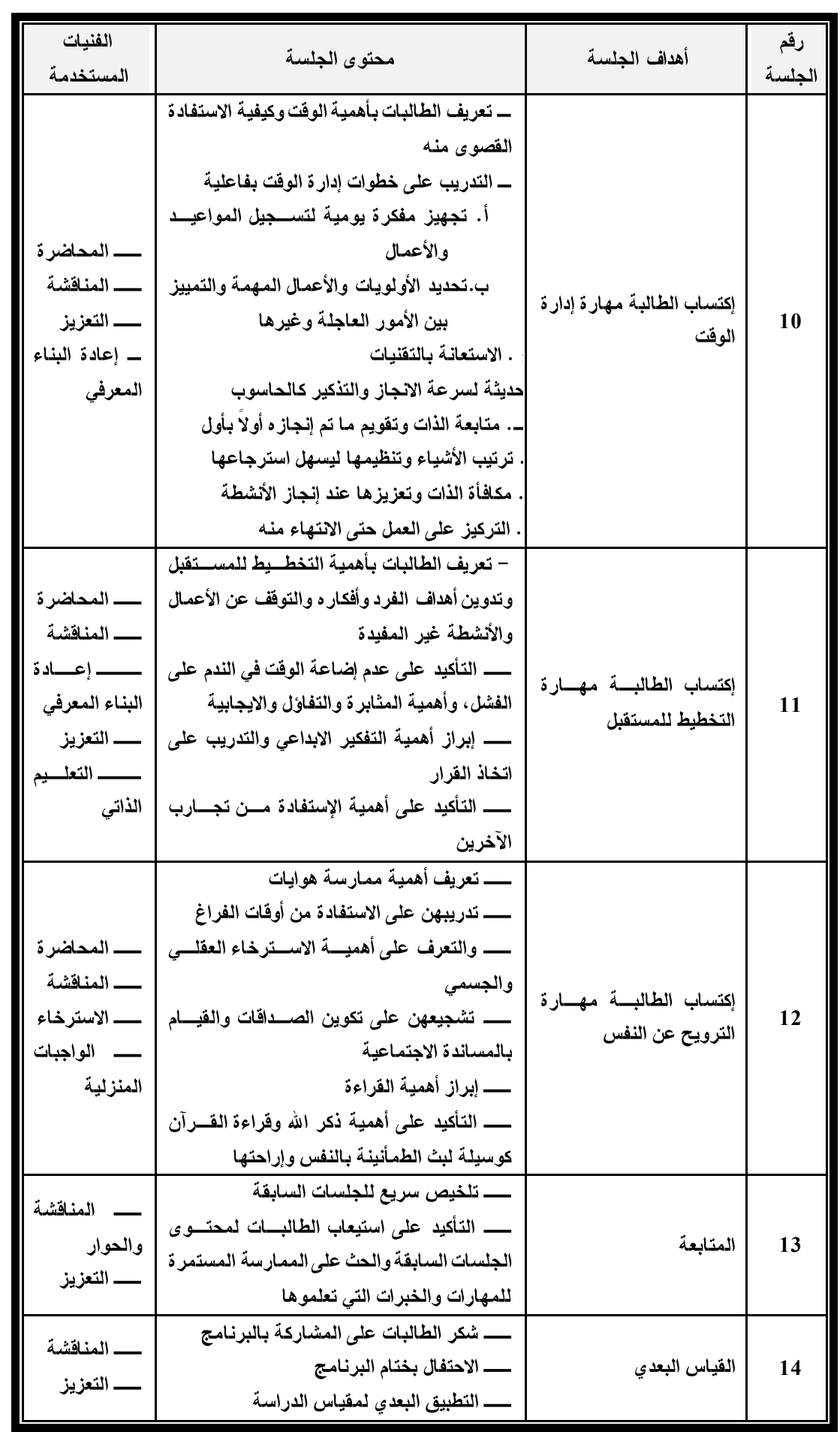

و) تقويم البرنامج: ويتضمن الاجر اءات التالية 
1. تقويم قبلي: تم عرض البرنامج على مجموعة من المحكمين لإبداء آر ائهم

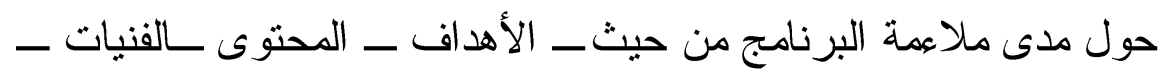
عدد الجلسات ،وقد قامت الباحثة بالتعديلات التي أثنار بها السادة المحكمين.

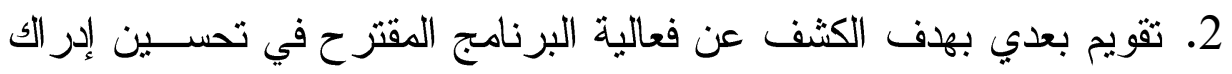
الطالبات لجودة الحياة.

3. قياس تتبعي بهدف الكثف عن استمرار وبقاء أثز البرنامج المقترح بعــ انتهائه.

\section{- نتائج الار اسةّة ومناقشتها:}

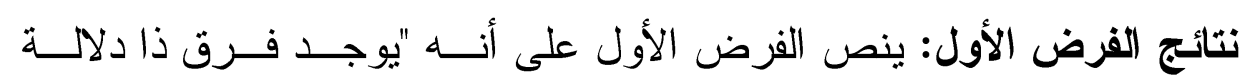

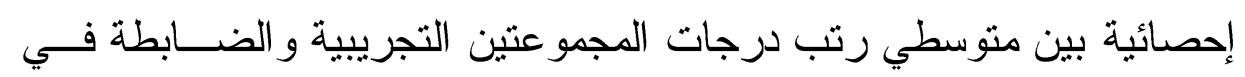
إدر الك جودة الحياة بعد تطبيق البرنامج الإرشادي لصالح المجموعة التجريبية

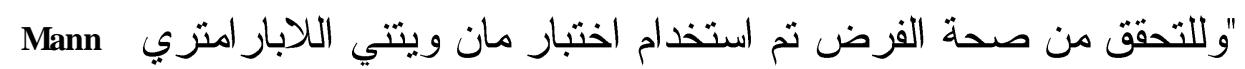

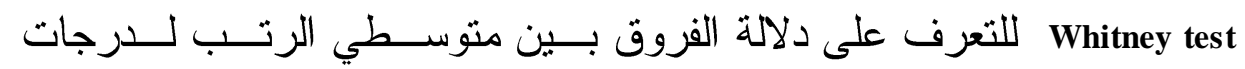

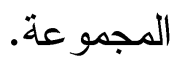

جدول (8): دلاكة الفرق بين متوسطي الرتب لارجات المجموعة التجريبية

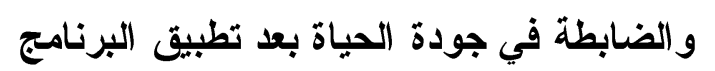

\begin{tabular}{|c|c|c|c|c|c|c|}
\hline الدلالة & قيمـــة & مجمـــوع & 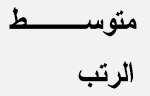 & العدد & مجموعـــــــــات & أبعاد جودة الحياة \\
\hline | غالة & 57.50 & $\begin{array}{l}177.00 \\
148.00\end{array}$ & $\begin{array}{l}14.75 \\
11.38\end{array}$ & $\begin{array}{l}12 \\
13\end{array}$ & الضابطريبية ـــــــة & جودة المجال التعليمي \\
\hline 0.01 & 20.50 & $\begin{array}{l}213.50 \\
111.50\end{array}$ & $\begin{array}{r}17.19 \\
8.58\end{array}$ & $\begin{array}{l}12 \\
13\end{array}$ & الضابطة التبية & جودة المجال النفسي \\
\hline 0.05 & 42.00 & $\begin{array}{l}192.00 \\
133.00\end{array}$ & $\begin{array}{l}16.00 \\
10.23\end{array}$ & $\begin{array}{l}12 \\
13\end{array}$ & الضابطة التيبية & جودة المجال الصحي \\
\hline 0.01 & 33.50 & $\begin{array}{l}200.50 \\
124.50\end{array}$ & $\begin{array}{r}16.71 \\
9.58\end{array}$ & $\begin{array}{l}12 \\
13\end{array}$ & الضابطة التبية & 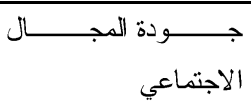 \\
\hline غالة لـــر & 61.50 & $\begin{array}{l}172.50 \\
152.50\end{array}$ & $\begin{array}{l}14.38 \\
11.37\end{array}$ & $\begin{array}{l}12 \\
13\end{array}$ & الضابطة التريية & 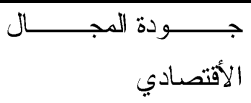 \\
\hline
\end{tabular}




\begin{tabular}{|c|c|c|c|c|c|c|}
\hline 0.01 & 21.00 & $\begin{array}{l}213.00 \\
112.00\end{array}$ & $\begin{array}{r}17.75 \\
8.62\end{array}$ & $\begin{array}{l}12 \\
13\end{array}$ & الضابطة التجيية & جودة مجال المعتقدات \\
\hline 0.01 & 15.50 & $\begin{array}{l}218.50 \\
106.50\end{array}$ & $\begin{array}{r}18.21 \\
8.19\end{array}$ & $\begin{array}{l}12 \\
13\end{array}$ & الضجابطة & الدرجة الكلية \\
\hline
\end{tabular}

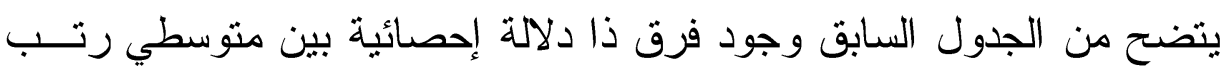

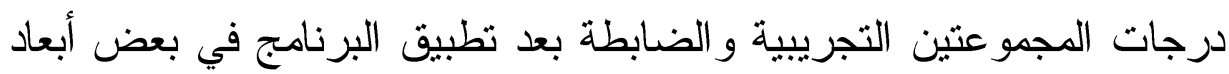

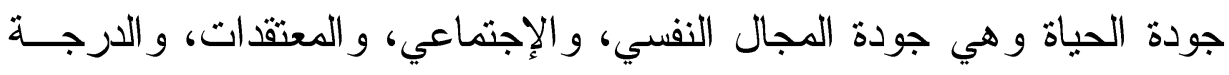

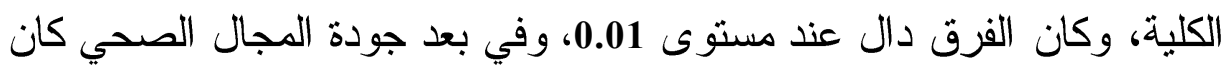

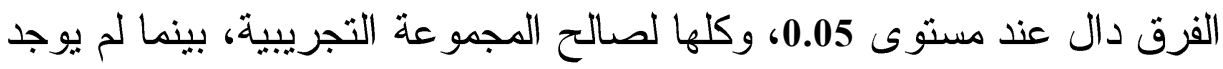

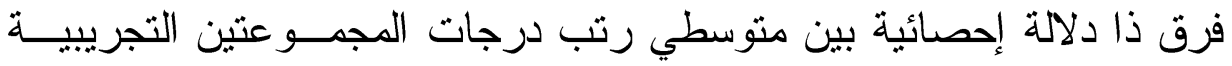
و الضابطة في بُعدين هما جودة المجال التعليمي وجودة المجال الأقتصادي.

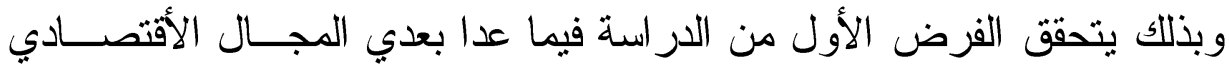

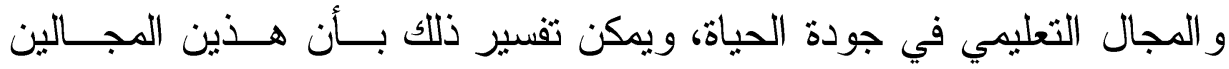

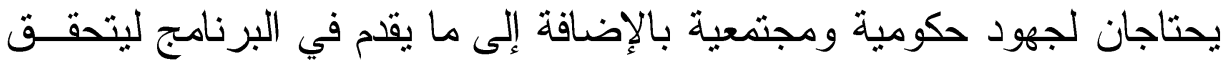

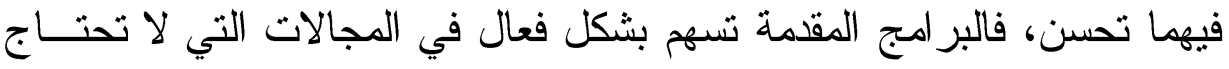
إلى مؤسسات وميز انيات مثل المجال النفسي و الإجتماعي و المعتقدات ولكـنـن فئن النواحي الإقتصادي و التعليمية فهي تحتاج بالإضافة إلى البر امج إلى تضــافر

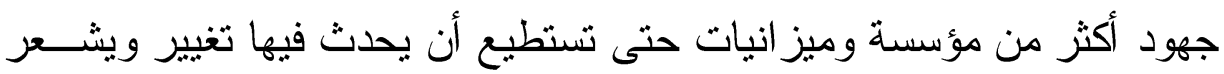

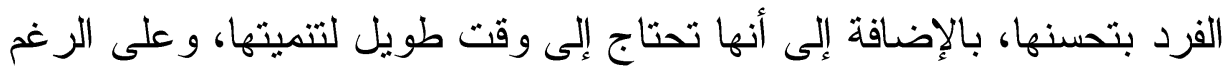

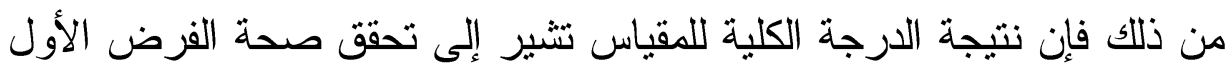

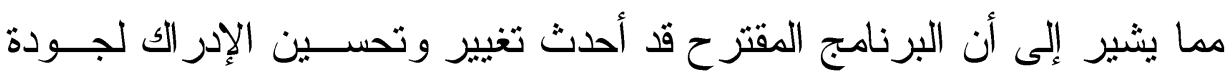

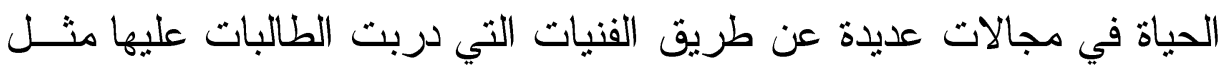
الاسترخاء، إعادة البناء المعرفي، واستخدام أسلوب حل المشكلات، و واستبدال

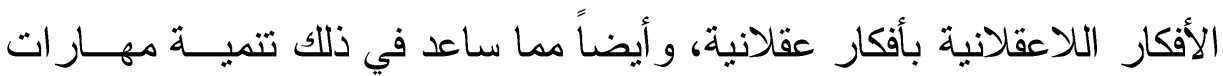
إدارة الوقت والتو اصل الاجتماعي، وتوكيد الذات مما ساهم في تحسين إدر اكهم 


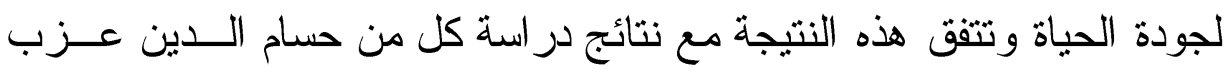
(2004) ، وصلاح العر اقي ومصطفى رمضان (2005) ، هانم محمــد (2009) محمد أبو راسين (2012) وتتفق هذه النتيجة مع نتائج دراسة كل من اعتــدال

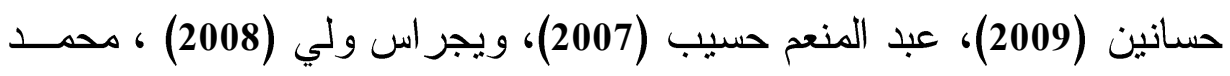
عبد الوهاب (2012) التي تؤكد حدوث تحسن في إدر الك الطالبات لجودة الحياة بعد ممارستهن لبعض الفنيات و المهار ات المتضمنة في البرنامج المقتر ح.

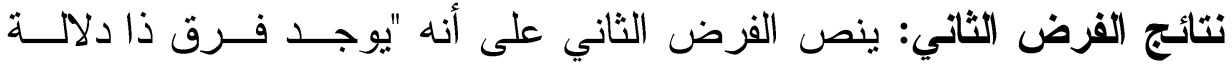

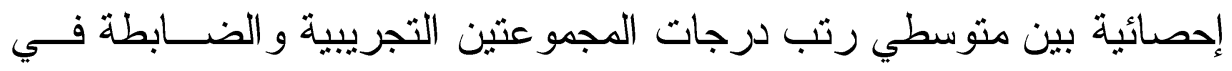
أساليب مو اجهة أحداث الحياة الضاغطة بعد تطبيق البرنامج الإرشادي لصاتح المجمو عة التجريبية" مون الجية

وللتحقق من صحة ذلك الفرض استخدت الباحثة اختبار مان ويتني (قيمة U) للمقارنة بين المجمو عتين، وجاءت النتائج كما في جدول (9). جدول (9) دلالة الفرق بين متوسطي الرتب لارجات المجموعة التجريبية و الضابطة

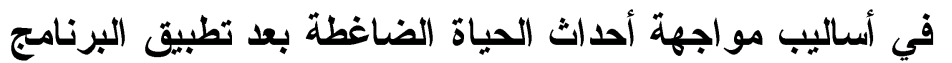

\begin{tabular}{|c|c|c|c|c|c|c|}
\hline الالالة & قيمة U & مجمـــــوع & متوبـــــ & العدد & مجموعـــــــة & الأبعاد \\
\hline 0.01 & 17.50 & $\begin{array}{l}216.50 \\
108.50\end{array}$ & $\begin{array}{r}18.04 \\
8.35\end{array}$ & $\begin{array}{l}12 \\
13\end{array}$ & الضابطة التجيبية & الألمعـــــاليب \\
\hline غئـــر & 63.00 & $\begin{array}{l}171.00 \\
154.00\end{array}$ & $\begin{array}{l}14.25 \\
11.85\end{array}$ & $\begin{array}{l}12 \\
13\end{array}$ & الضابطة التجريبة & الألاينية \\
\hline 0.01 & 31.00 & $\begin{array}{r}2.3 .00 \\
122.00\end{array}$ & $\begin{array}{r}16.92 \\
9.38\end{array}$ & $\begin{array}{l}12 \\
13\end{array}$ & الضابطة التريبية & 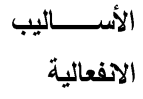 \\
\hline 0.01 & 19.50 & $\begin{array}{l}214.50 \\
110.50\end{array}$ & $\begin{array}{r}17.88 \\
8.50\end{array}$ & $\begin{array}{l}12 \\
13\end{array}$ & الضابطة التجيية & الفسيولوجية الأســـــيب \\
\hline 0.01 & 41.00 & $\begin{array}{l}193.00 \\
132.00\end{array}$ & $\begin{array}{l}16.08 \\
10.15\end{array}$ & $\begin{array}{l}12 \\
13\end{array}$ & الضابطريبية & الأاجتـــــــاليب \\
\hline 0.01 & 3.00 & $\begin{array}{r}231.00 \\
94.00\end{array}$ & $\begin{array}{r}19.25 \\
7.23\end{array}$ & $\begin{array}{l}12 \\
13\end{array}$ & الضبابطة & الكلية \\
\hline
\end{tabular}


يتضح من الجدول السابق وجود فرق ذا دلالة إحصائية عند مستوى 0.01 بين

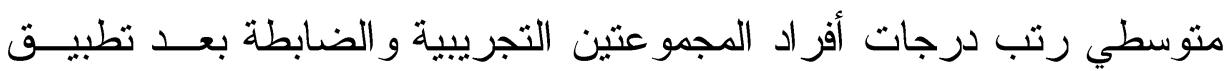

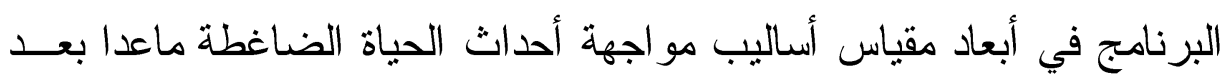

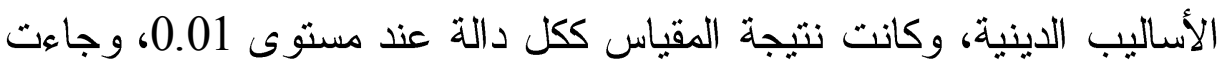

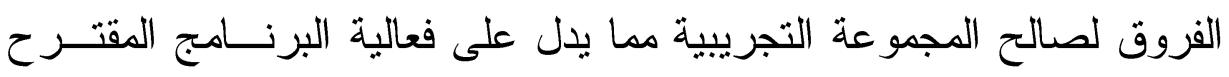

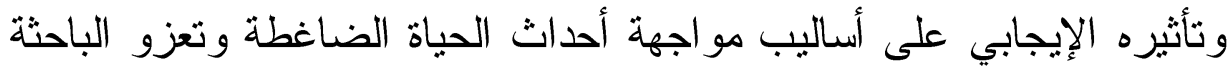

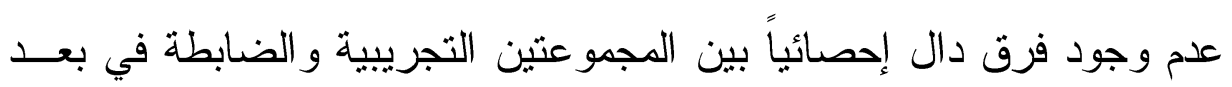

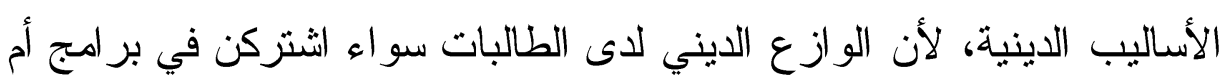

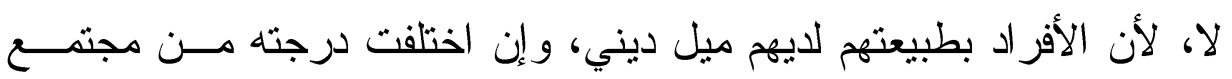

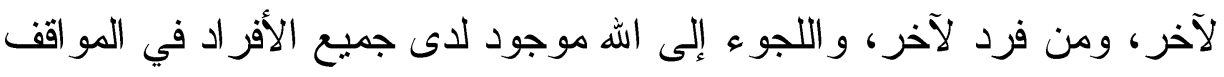

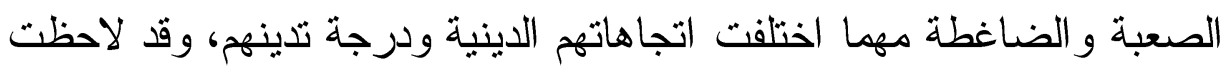

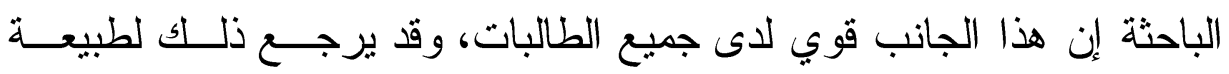

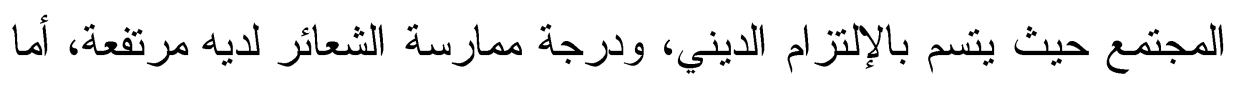

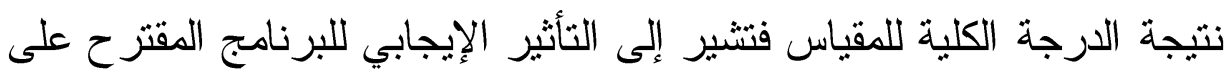

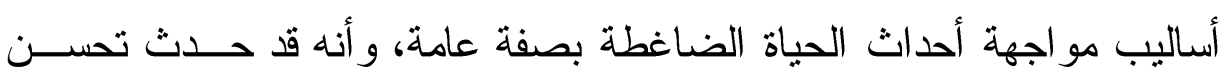

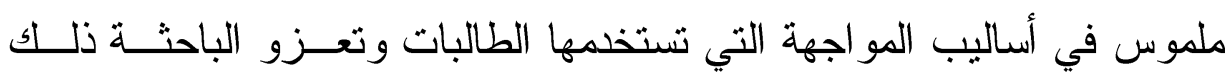
التحسن إلى ما تضمنه البرنامج من خبر ات وأنشطة ساهمت في زيادة وعـي لئي الطالبات بالأساليب الجيدة و تجنب السلبية المستخمة في مو اجهة أحداث الحياة

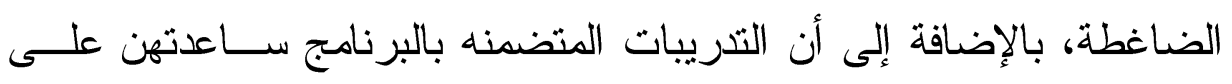
ممارسة الأساليب الجيدة لمواجهة الضغوط كإدارة الوقت و الإنفعالات، و إيضاً

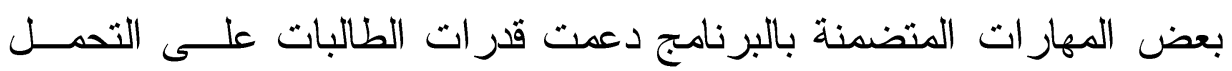

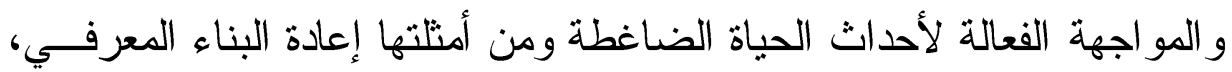

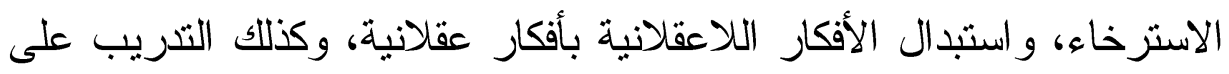

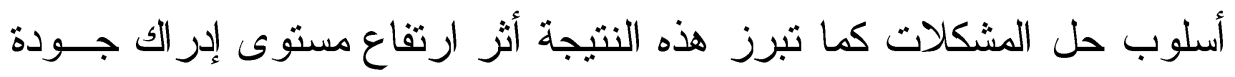


الحياة على أساليب مو اجهة الأحداث الضاغطة مما يؤكد انعكاس جودة الحيــاة

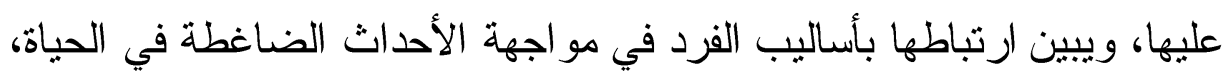
وتتفق هذه النتيجة مع نتائج دراسة كل من مارك و آخرون (2002) ،و نعيمسـة

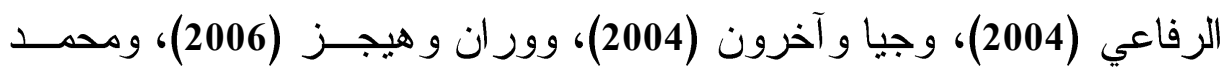

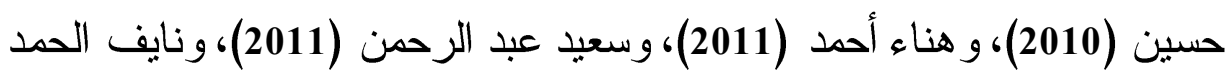

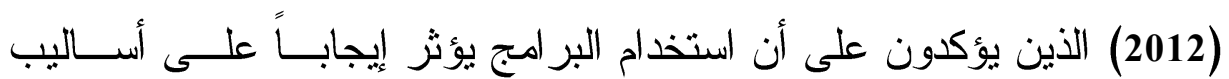
مو اجهة الأحداث الضاغطة. نتائج الفرض الثالث: ينص الفرض الثالث على أنه "لا يوجد فــرق ذا دلالـــة

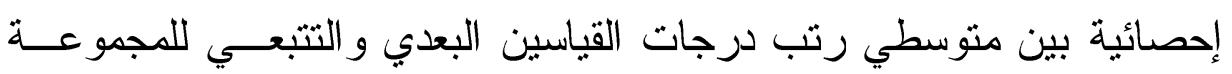
التجريبية في جودة الحياة". وللتحقق من ذلك استخدت الباحثة "اختبار ويلكوكسون" لحساب دلالة الفروق بين متوسطات الرتب، كما يوضح ذلك الجدول التالي. جدول (10): دلاكة الفرق بين متوسطي الرتب للمجموعة التجريبية في القياسين البعدي والتتبعي في جودة الحياة

\begin{tabular}{|c|c|c|c|c|c|c|}
\hline الدلامة & قيمـة & 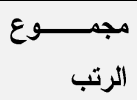 & متوبـــــــ الرتب & العدد & مجموعـــــــة & الأبعاد \\
\hline غالة & 0.53 & $\begin{array}{l}2.00 \\
4.00\end{array}$ & $\begin{array}{l}2.00 \\
2.00\end{array}$ & $\begin{array}{l}1 \\
2 \\
9\end{array}$ & رتب رتب موجبة رتبة & جودة المجــال \\
\hline غالة & 0.27 & $\begin{array}{l}3.50 \\
2.50\end{array}$ & $\begin{array}{l}1.75 \\
2.50\end{array}$ & $\begin{array}{l}2 \\
1 \\
9\end{array}$ & رتب رتب موجبة رتبة & جودة المجـــال \\
\hline غالة & 0.44 & $\begin{array}{l}2.00 \\
1.00\end{array}$ & $\begin{array}{l}2.00 \\
1.00\end{array}$ & $\begin{array}{r}1 \\
1 \\
10\end{array}$ & رتب رتب موجبة & الصودة المجـــال \\
\hline غالة & 1.34 & $\begin{array}{l}3.00 \\
0.00\end{array}$ & $\begin{array}{l}1.50 \\
0.00\end{array}$ & $\begin{array}{r}2 \\
0 \\
10\end{array}$ & رتب رتب موجبة رتبة & الاجتماعي المجــال \\
\hline غيـــر & 1.34 & $\begin{array}{l}3.00 \\
0.00\end{array}$ & $\begin{array}{l}1.50 \\
0.00\end{array}$ & $\begin{array}{l}2 \\
0\end{array}$ & رتب موجبة & جودة المجـــال \\
\hline
\end{tabular}




\begin{tabular}{|c|c|c|c|c|c|c|}
\hline الالالة & قيمـة & 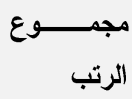 & متوســـــــــ & العدد & مجموعـــــــــة & الأبعاد \\
\hline دالة & & 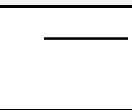 & - & 10 & رتب رتبالبة & الأقتصادي \\
\hline غالة & 1.60 & $\begin{array}{l}6.00 \\
0.00\end{array}$ & $\begin{array}{l}2.00 \\
0.00\end{array}$ & $\begin{array}{l}3 \\
0 \\
9\end{array}$ & رتب رتب موجبة & جودة مجـــال \\
\hline غالة & 0.73 & $\begin{array}{l}7.00 \\
3.00\end{array}$ & $\begin{array}{l}3.50 \\
1.50\end{array}$ & $\begin{array}{l}2 \\
2 \\
8\end{array}$ & رتب رتب موجبة رتبة رتباو & الدرجة الكلية \\
\hline
\end{tabular}

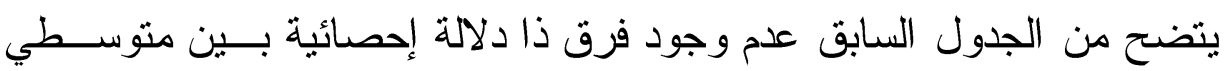
رتب درجات القياسين البعدي و التتبعي للمجموعة التجريبية في جودة الحيــــاة

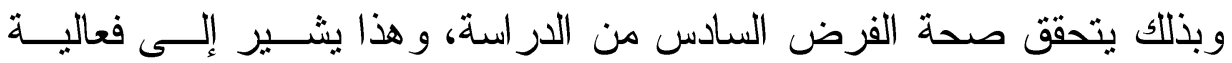
البرنامج في تحسين جودة الحياة واستمر ار تأثيره على سلوك أفر اد المجموعة ولثة

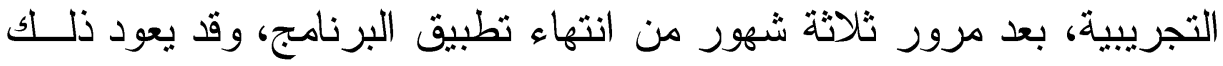

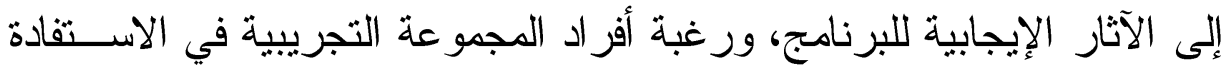

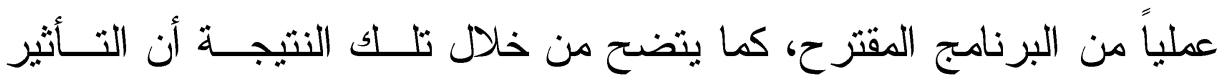
الإيجابي للبرنامج على جودة الحياة أدى إلى تعديل سلوكيات الطالبات الصحية

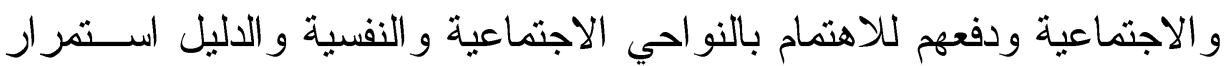

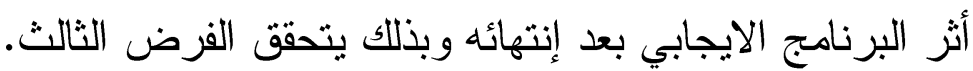

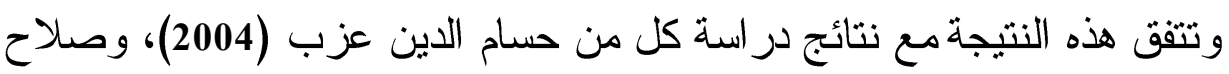
الدين عر اقي (2005)، و هانم محمد (2009)، ومحمد أبو راسين (2012).

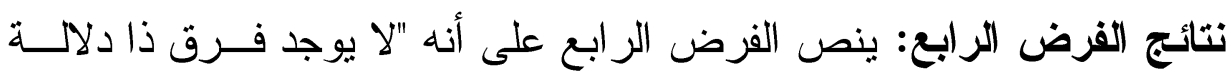

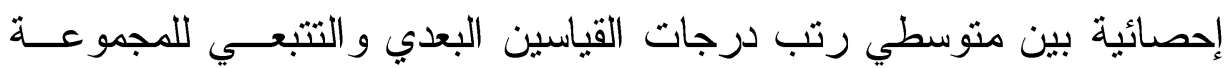
التجريبية في أساليب مو اجهة أحداث الحياة الضاغطة".

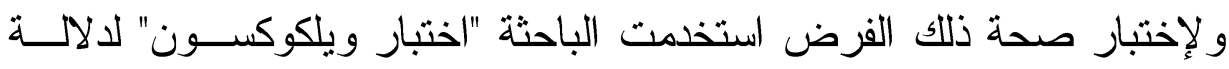
الفرق بين متوسطات الرتب، ويوضح ذلك الجدول التالي. 


\section{مجلة الدراسات الثربيوية و الأسانية ـ كلية الثربية ـ جامعة دمنهور ـ المجلد الخامس العدد (1) لسنة 2013}

جدول (11):دلالة الفرق بين متوسطي الرتب لارجات المجموعـة التجريبيـة فـي

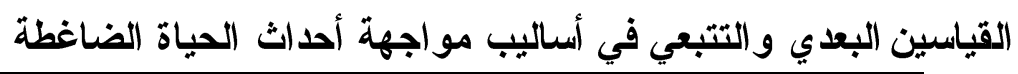

\begin{tabular}{|c|c|c|c|c|c|c|}
\hline الدلالة & $\begin{array}{r}\text { قيمة } \\
\text { Z }\end{array}$ & مجــــــوع & متوســــــــ & العدد & نوع الرتب & الأبعاد \\
\hline غالة & 1.36 & $\begin{array}{r}22.00 \\
6.00\end{array}$ & $\begin{array}{l}4.40 \\
3.00\end{array}$ & $\begin{array}{l}5 \\
2 \\
5\end{array}$ & رثب رنب موجبة رنسالة & المعرفية \\
\hline غالة غيـــر & 0.30 & $\begin{array}{l}5.00 \\
5.00\end{array}$ & $\begin{array}{l}2.50 \\
2.50\end{array}$ & $\begin{array}{l}2 \\
2 \\
8\end{array}$ & رثب رنب مونبة رنساوية & الأساليب الاينية \\
\hline غالة غيــر & 1.70 & $\begin{array}{r}24.00 \\
4.00\end{array}$ & $\begin{array}{l}4.00 \\
4.00\end{array}$ & $\begin{array}{l}6 \\
1 \\
5\end{array}$ & رثب رتب موجبة رنسالبة & الالففعالية \\
\hline غالة غئر & 0.47 & $\begin{array}{l}45.00 \\
33.00\end{array}$ & $\begin{array}{r}5.00 \\
11.00\end{array}$ & $\begin{array}{l}9 \\
3 \\
0\end{array}$ & رتب رتب موجبة رنبة & الفسيولوجية \\
\hline غالة غئر & 1.09 & $\begin{array}{l}8.00 \\
2.00\end{array}$ & $\begin{array}{l}2.67 \\
2.00\end{array}$ & $\begin{array}{l}3 \\
1 \\
8\end{array}$ & رتب رتب موجبة رنبة & الإجتماعية \\
\hline غالة غبــــر & 0.94 & $\begin{array}{l}51.00 \\
27.00\end{array}$ & $\begin{array}{l}8.50 \\
4.50\end{array}$ & $\begin{array}{l}6 \\
6 \\
0\end{array}$ & رتب رتب موجبة & اللدرجة الكلية \\
\hline
\end{tabular}

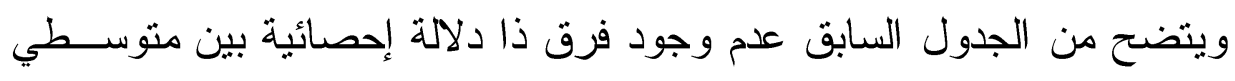

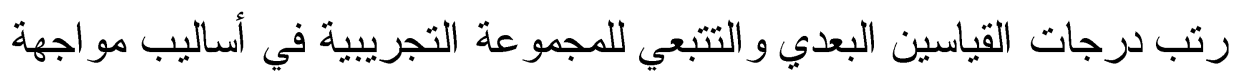
أحداث الحياة الضاغطة، وبذلك يتحقق صحة الفرض السادس من الدراســـة،

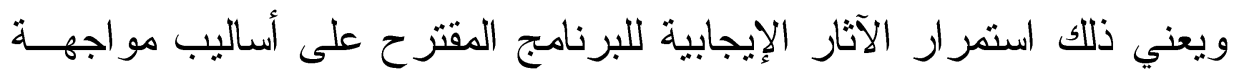

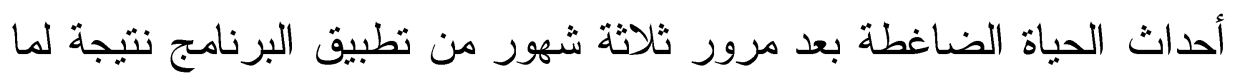

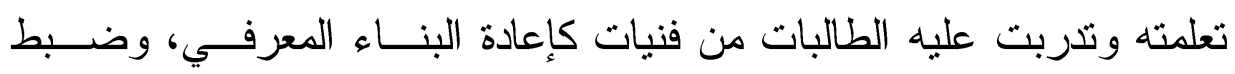

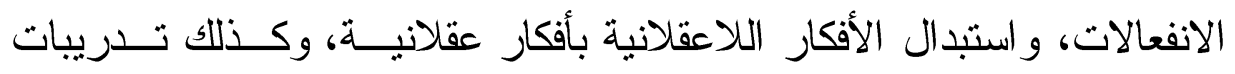
الاسترخاء، مما يشير إلى الأثز الإيجابي لتحسين إدرالك جودة الحياة الإنكان على تبني 
الطالبات لسلوكيات إيجابية وصحية انعكست علي أساليب مو اجهتن لأحسـداث

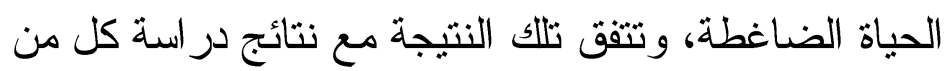

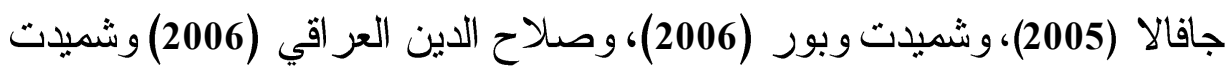

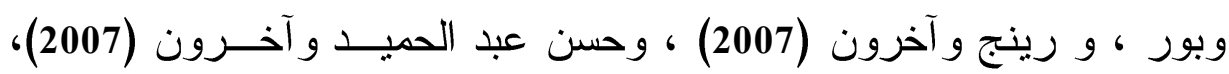

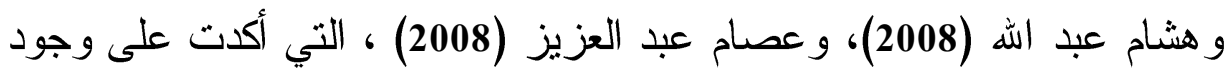

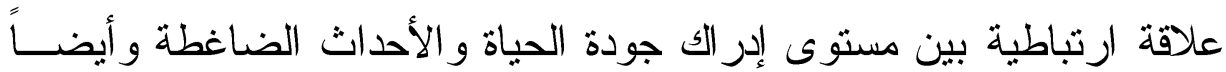
أساليب مو اجهتها، وكذلك الصحة النفسية.

\section{• التوصبات :}

في ضو ء النتائج التي توصلت إليها الدر اسة الحالية، هناك عدة توصيات مــن أهمها :

1. الإستعانة ببر امج تحسين جودة الحياة من قبــل المرشـدين النفسـيين و الأكاديميين بالجامعات.

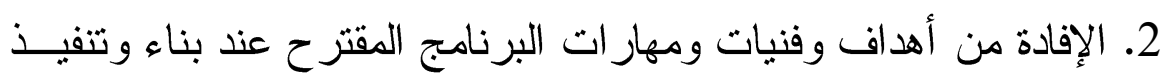
أنشطة صفية ولا صفية.

3. تفعيل دور مر اكز الإرشاد في الجامعات لتحسين جودة الحياة.

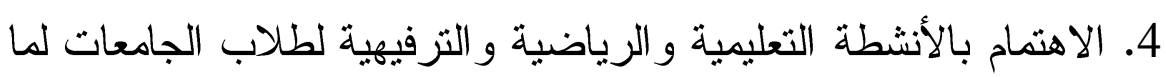

$$
\text { لها من آثار إيجابية. }
$$

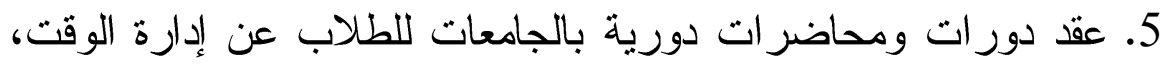

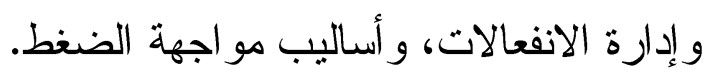

6. تفعيل دور المرشد النفسي و التزبوي بالمدارس و والجامعــات لمســـــاعدة الطلاب علي مو اجهة أحداث الحياة الضاغطة.

\section{• البحوث المقترحة}

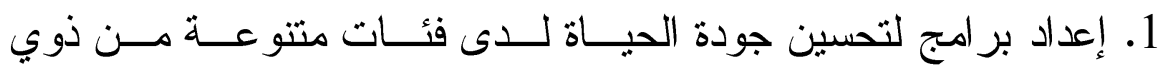

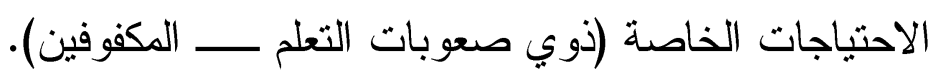
doi : 10.12816/0001050 
مجلة الدراسات التزبوية و الاسانية ـ كلية التربية - جامعة دمنهور - المجلد الخامس العدد (1) لسنة 2013

2. دراسة فاعلية البرامج القائمة على الأنشطة الصفية و اللاصــفية فـي دي تحسين جودة الحياة.

3. دراسة أثز تثمية بعض جودة المهار ات الحياتية على جودة الحياة.

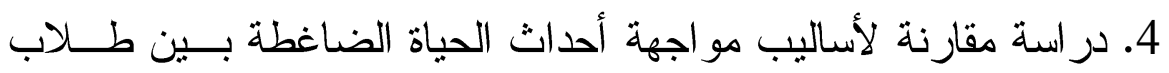

الجامعة العاديين و المتفوقين و المتعثرين.

5. در ساسة جودة الحياة و علاقتها بإتخاذ القرار.

6. در اسة أساليب مو اجهة أحداث الحياة الضاغطة و علاقتها بفاعلية الذات. 


\section{المر اجس}

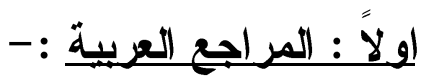

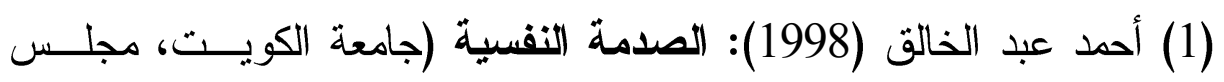

النشر العلمي).

(2) أحمد عبد الله العيافي (2012): الصلابة النفسية وأحداث الحياة الضاغطة لاى عينة من الطلاب الأيتام والعاديين بمدينة مكة ولة

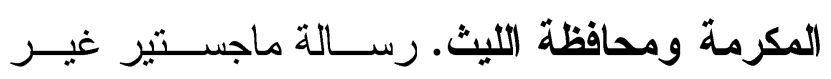

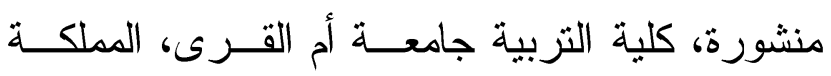
العربية السعودية.

أحمد عكاشة (2003): الطب النفسي المعاصر . القاهرة، مكتبة الانجلــو المصرية.

آرون بيك جان سكوت ومسـارك وليـامز (2002): العـلاج المعرفـي

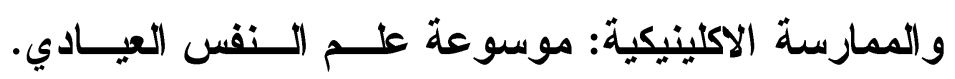

تزجمة: حسن مصطفى ، (القاهرة، مكتبة زهر اء الشرق).

(5تدال عباس حسانين (2009): إتقان تعلم علم النفس وتأثيره على إدر الك

جودة الحياة لدى طلاب كلية التزبية جامعة قناة الســويس.

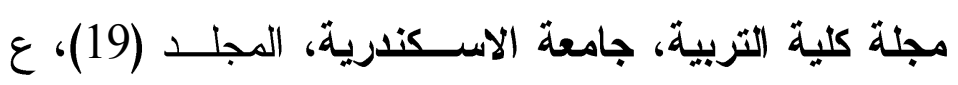

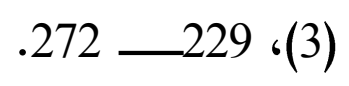

(6) السيد كامل منصور (2007): جودة الحياة وعلاقتها بالمز اج الانفعـالي

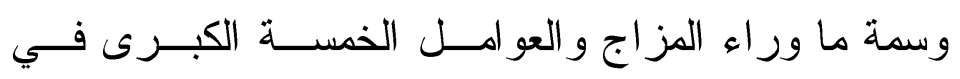

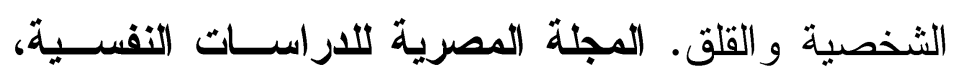

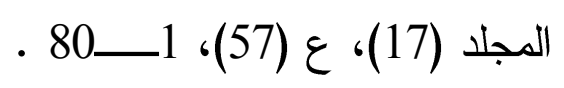

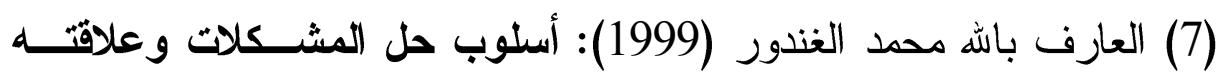

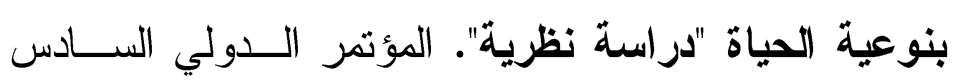


لمركز الإرشاد النفسي، جامعة عين شمس "جــودة الحيــاة

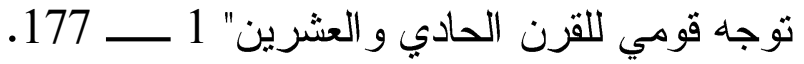
أماني عبد المقصود عبد الو هاب وسميرة محمد ســند (2010): جـودة الحياة الأسرية وعلاقتها بفاعلية الأات لاى عينة من الأبناء المراهقين. المؤتمر السنوي الخامس عشر، مركز الإرشــاد

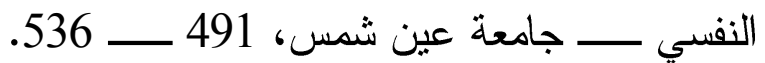

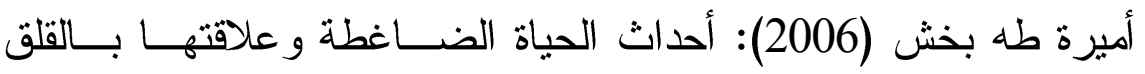

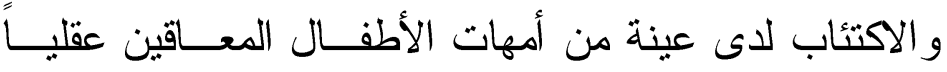

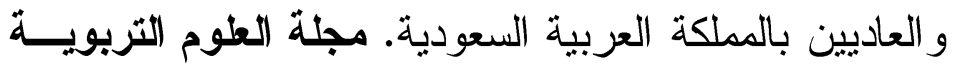

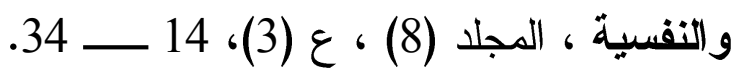

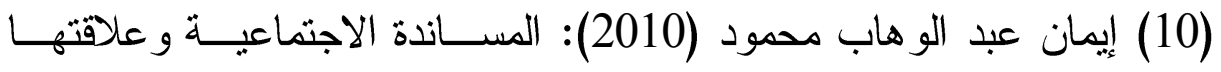

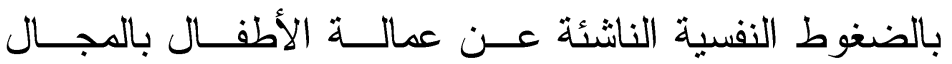
الزر اعي. دراسات عربية في علم النفس، المجلـــ (9)، ع

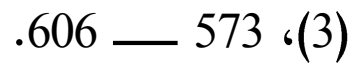

(11) بشرى إسماعيل (2005): ضغوط الحياة والاضطر ابات النفسية. (مكتبة

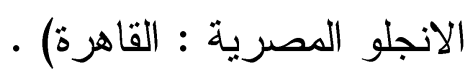

(12) بشير الرشيدي (2001): سلسلة تشــخيص الاضــطر ابات النفسـية،

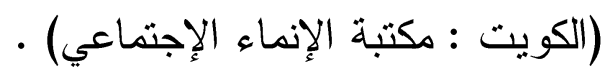

(13) حسام الدين عزب (2004): برنامج إرشادي لخفض الإكتئابية وتحسين

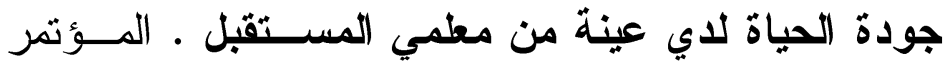

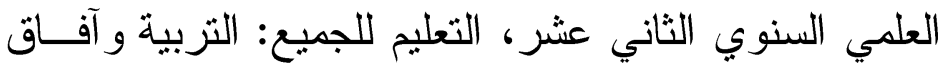
جديدة في تعليم الفئات المهمشة في الوطن العربي، مركـز الإرشاد، جامعة عين شمس، 28-29 مارس، لهاب، 575- 605 . 
(14) حسن مصطفى عبد المعطي (2005): الإرشاد النفسي وجودة الحيـاة

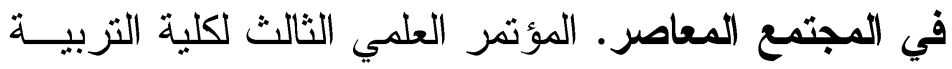

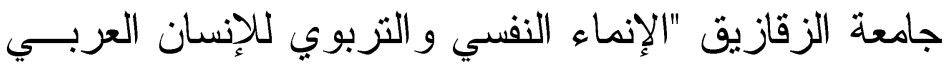

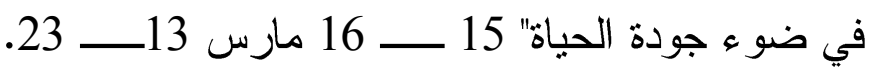

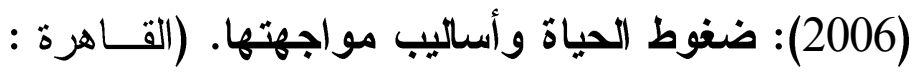

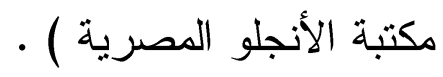

(16) حكيمة آيت حمودة (2012): دور أساليب المواجهة في التعامل مع قلق

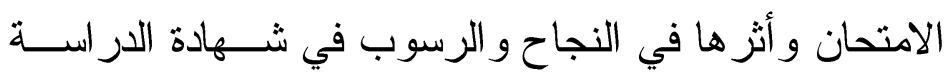

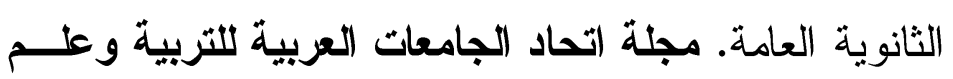

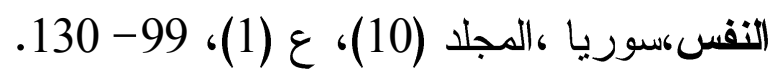

(17) حمدي علي الفرماوي (1999): جودة الحياة فـي جــوهر الإنســان.

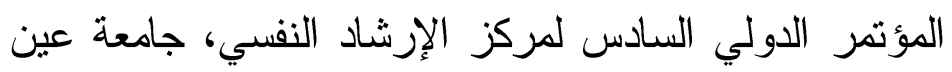

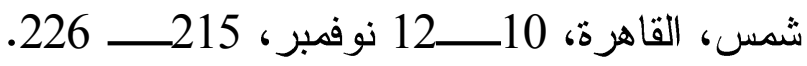
(18) حميدة السيد العربي (2011): فعالية برنامج إرشادي معرفي سلوكي في خفض بعض الإضطر ابات الإجتماعية الإنفعالية لدى الأطفال

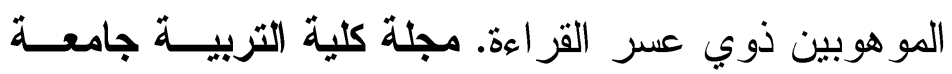

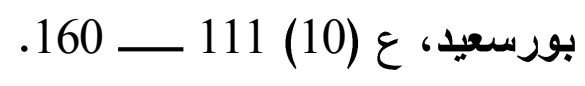

(19) حنان عبد الرحمن سعيد (2010): فاعلية برنامجج التدخل المهني فــي

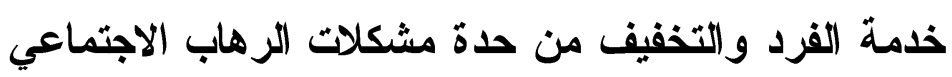

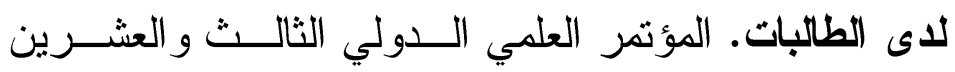

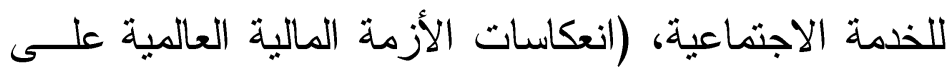

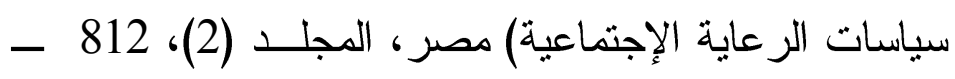
.872 
(20 ) حنان عبد الرحيم المالكي (2011): الإكتئاب و المعنـي الثخصـيسي وجودة الحياة النفسية لدي عينة من طالبات كلية التربية في

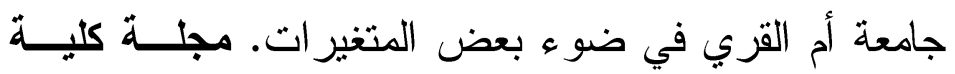

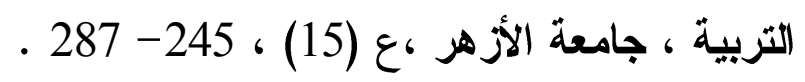

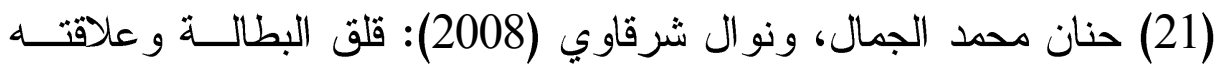

بجودة الحياة وفاعلية الذات لاى طلاب السنة النهائية بكليـــة

التزبية جامعة المنوفية. مجلة البحوث النفسية والتربوية. ع عابه

(22) خالد محمد العبدلي (2012): الصلابة النفسـية وعلاقتهـــا بأســاليب

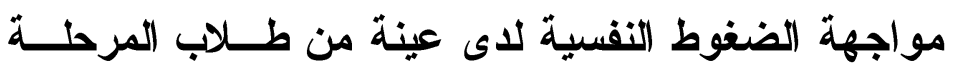

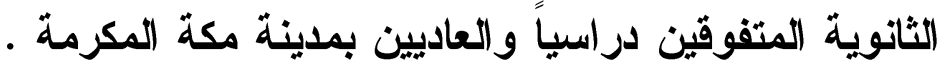

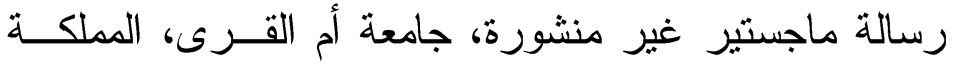

$$
\text { العربية السعودية. }
$$

(23) ديفيد فونتانا (1994): الضغوط النفسية. ترجمة حمدي الفرماوي ورضا

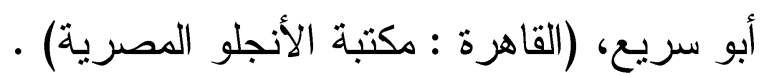

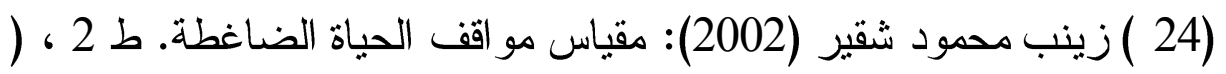

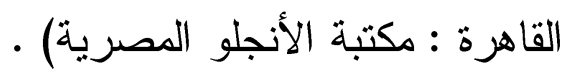

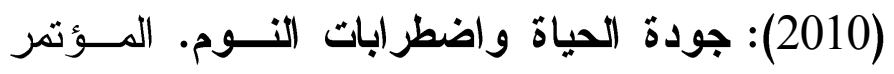

الاقليمي الثاني لعلم النفس. رابطة الإخصـــائيين النفسـيـين

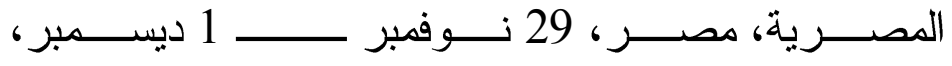

$.790 \_773$

(26) سامي عبد القوي (2002): أساليب التعامل مع الضـــوط و المظــــاهر

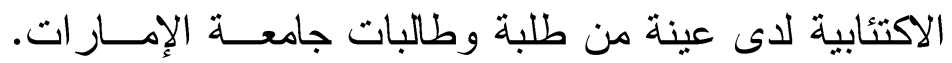


حولية كلية الآداب ، جامعة عين شمس، المجلــ(30) 309

$$
.361
$$

(27) سامي هاشم محمد (2001): جودة الحياة لدى المعوقين جسمياً والمسنين وطلاب الجامعة، مجلة الإرشاد النفسي، جامعة عين شمس،

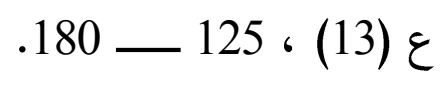

(28) سعاد محمد سليمان (2008): العلاقة بين التعـرض لأحسـاث الحيــاة

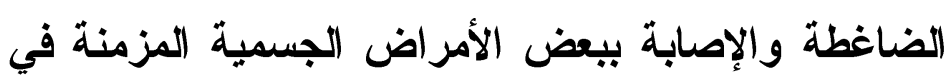

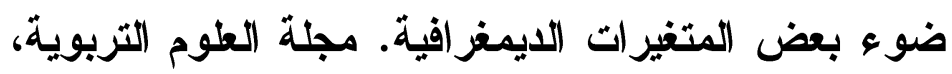

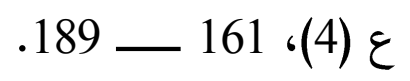

(29) سعيد عبد الرحمن محمد (2011): جودة الحياة واستر اتيجيات التعـايش (المو اجهة) للصم وضعاف السمع دراسة تحليلية. مجلة كلية

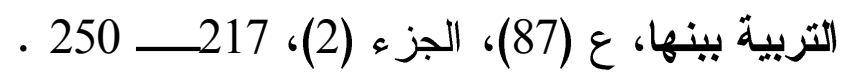

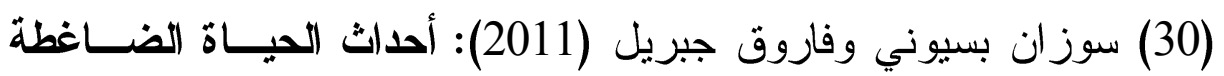
وأساليب مواجهتها والقلثى والاكتئاب لدى طالبات الجامعــة

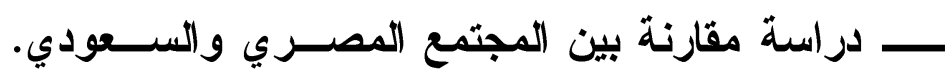

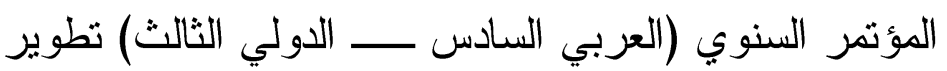
برامج التعليم العالي النوعي في مصر و الوطن العربي فــي

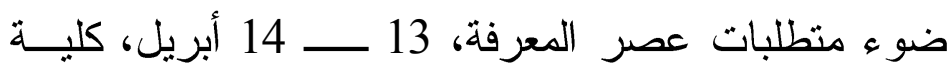
التزبية النوعية ، جامعة المنصورة ، 43- 68 .

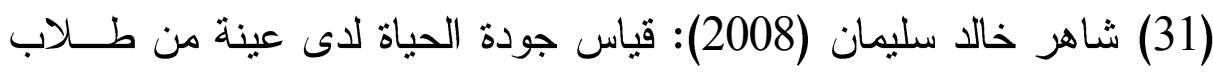

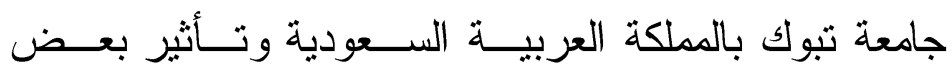

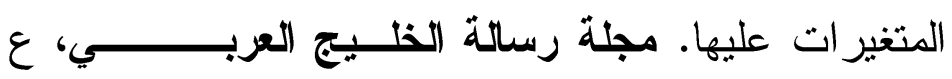

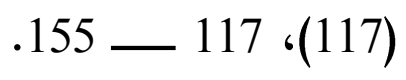


(32) صبحي سعيد الحارثي (2010): فاعلية برنامج إرشادي نفسي لتنميــة مهار ات الحياة لدى طلاب المرحلة الثانوية بمحافظة الطائف.

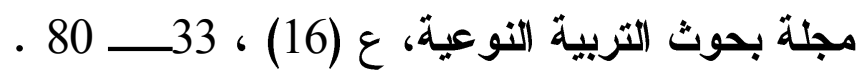
(33) صفاء عادل راثد (2009): ممارسة العلاج المعرفي السلوكي للتخفيف من حدة الرهاب الإجتماعي لاى طلاب الخدمة الإجتماعية.

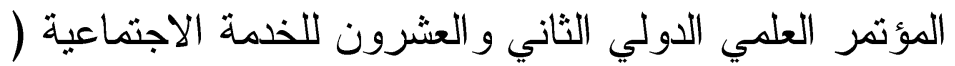

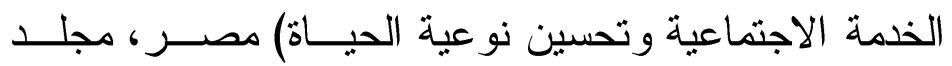

$$
\text { .5237_ } 5182 \text { ـ (11) }
$$

(34) صلاح الدين عر اقي ومصــطفى رمضـــان (2005): فعاليــة برنــامج

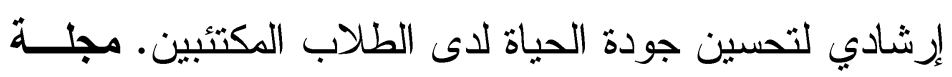

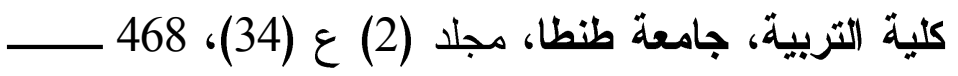

$$
.509
$$

(35) صلاح الدين عراقي (2006): فعالية برنامج إرشادي للآبــاء لتحسـين

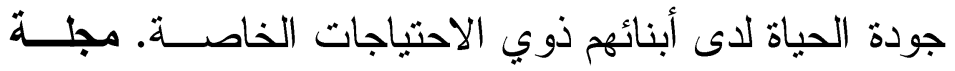

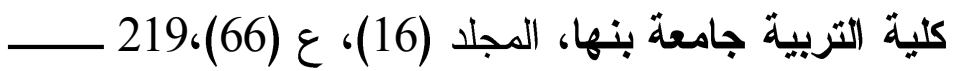

$$
.258
$$

(36) طلعت أحمد علي (2008): فعالية برنامج إرشادي مبني على الكفــاءة

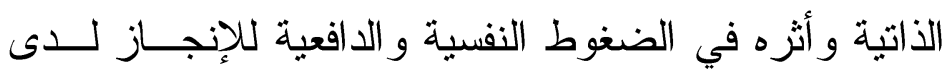

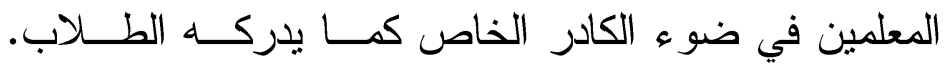
المجلة العلمية لكلية التربية. جامعة أسيوط، المجلــــ (24)،

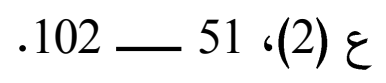

(37) عادل الأشول (2005): نوعية الحياة من المنظور الاجتماعي والنفسي

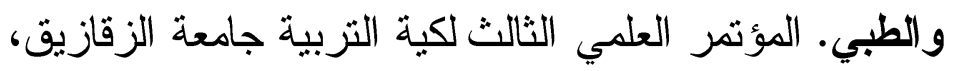


"الانماء النفسي و التربوي للإنسان العربي في ضوء جـودة

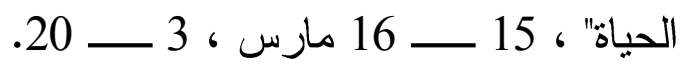

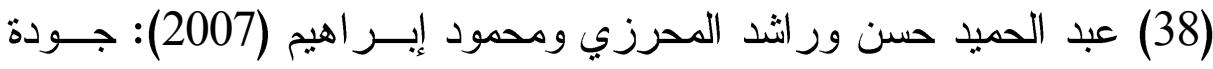

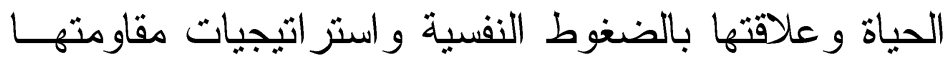

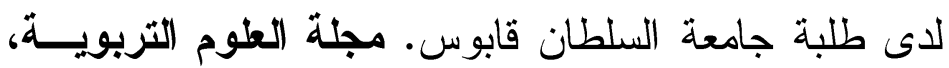

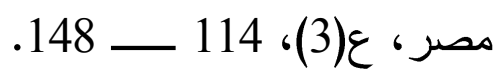

(39) عبد الحميد عبد العظيم رجيعة (2009): التحصيل الأكـاديمي و إدرالك جودة الحياة لدى مرتفعي ومنخفضي النكاء الإجتماعي مسنـ

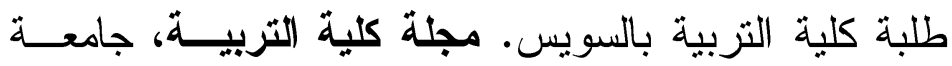

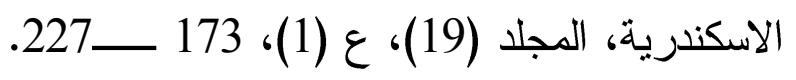

(40) عبد الستار إبر اهيم (1998): الإكتئاب " اضطر اب العصــر الحــديث ــ

$$
\text { فهمه وأساليب علاجه".( الكويت : عالم المعرفة ) . }
$$

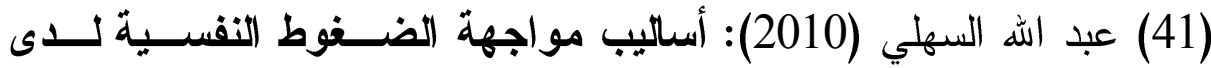
الثباب المترددين على مستثفى الطب النفســـي بالمداينــة المنورة وغير المرضى. رسالة دكتور اة غير منشورة، كلية

التربية، جامعة أم القرى، المملكة العربية السعودية.

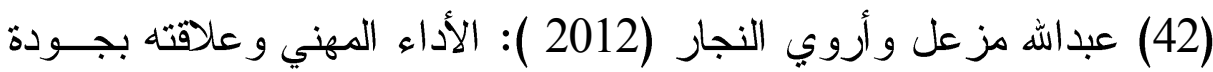
الحياة لدي معلمي التعليم العام بحفر الباطن ـ مجلة القراءة الهاء

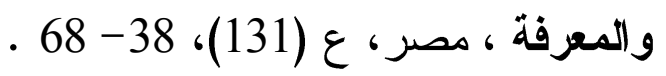

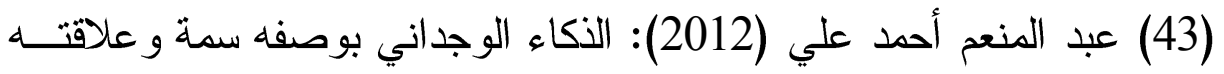

بأساليب المو اجهة لدى طلاب كلية التزبية بتيجي بالجماهيرية

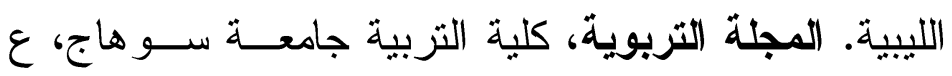

$$
\text { .286 } 205 \text { ـ } 205 \text { (32) }
$$


(44) عبد المنعم السيد حسيب (2007): أبعاد الـــكاء الانفعـالي و علاقتهــا

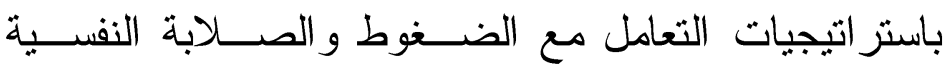
و الإحساس بالكفاءة الذاتية. مجلة الإرشاد النفسي، جامعــة

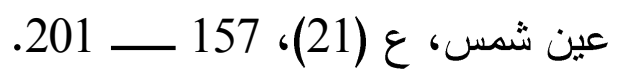

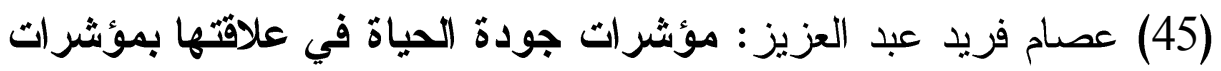

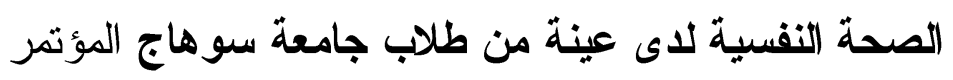

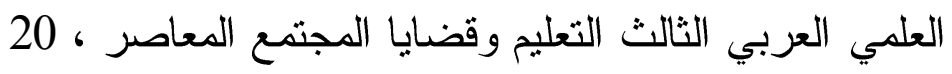

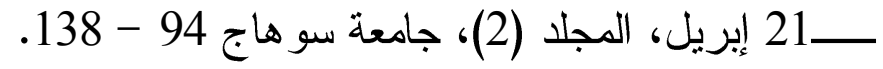

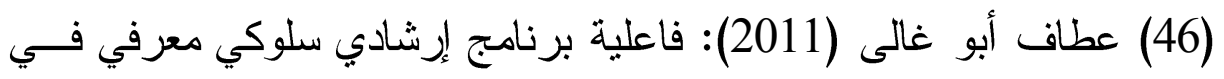

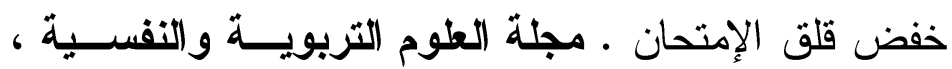

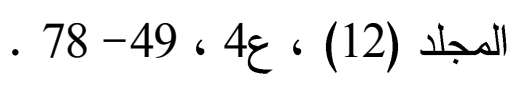

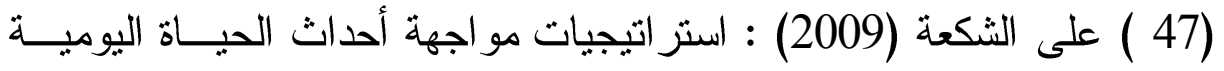

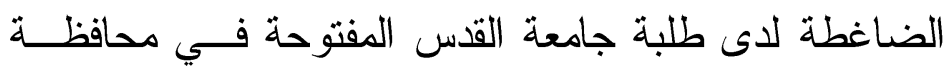

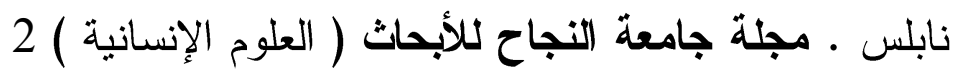

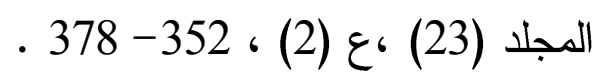

(48) علي عبد السلام (2000) : المساعدة الاجتماعيــة و أحــداث الحيــاة

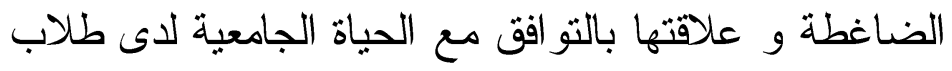
الجامعة المقيمين مع أسر هم و المقيمين في المدن الجامعية . مجلة علم النفس ، ع (53) ، (القاهرة : الهيئة المصــرية

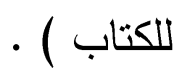

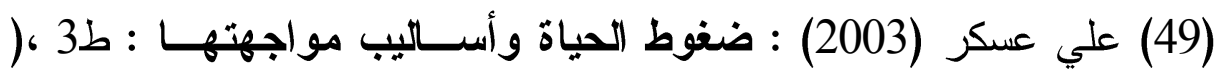

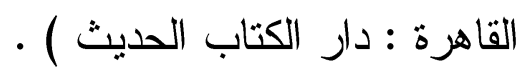
(50) عماد علي عبد الرزاق (2006) : أحداث الحياة الضاغطة و أســاليب

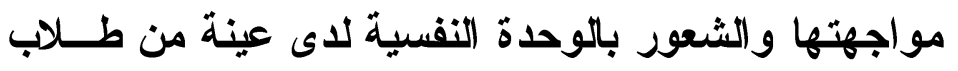


وطالبات الجامعة المصرية والسعودية ـ المؤتمر الســنوي

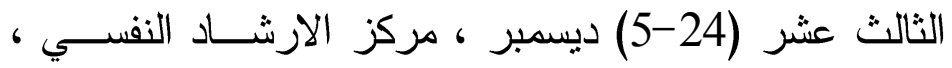

$$
\text { جامعة عين شمس . }
$$

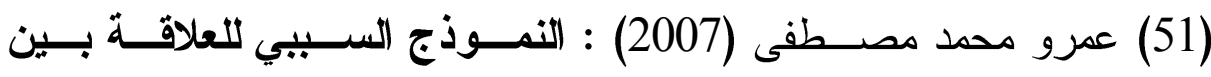
المتغيرات النفسية والاجتماعية وجودة أسلوب حياة الأسر

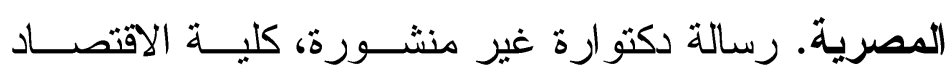

$$
\text { المنزلي، جامعة حلو ان. }
$$

(52) غالب محمد المشيخي (2009): قلث المستقبل وعلاقته بكل من فاعلية

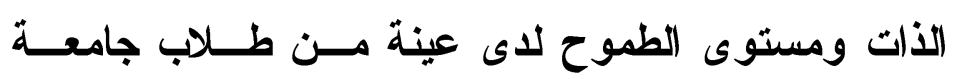

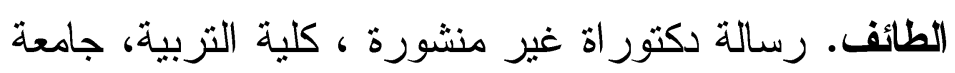
أم القرى المملكة العربية السعودية. (53) فاروق السيد عثان (2001): القلق وإدارة الضغوط النفسية.( القاهرة:

$$
\text { دار الفكر العربي) (عني) }
$$

(54 ) ليلي عبد اله المزروع (2009): أنماط التعلق وعلاقتها بالرضا عـن

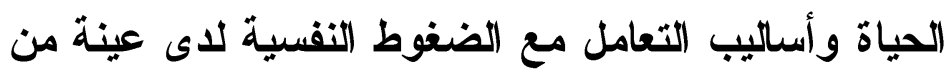
الزوجات في منتصف العمر • رسالة ماجستير غير منشورة،

كلية التزبية، جامعة أم القرى، المملكة العربية السعودية.

محمد إبر اهيم عيد (2005): مقدمة في الإرشاد النفسي. ( القـاهرة :

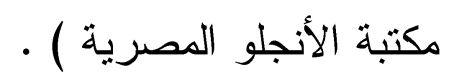

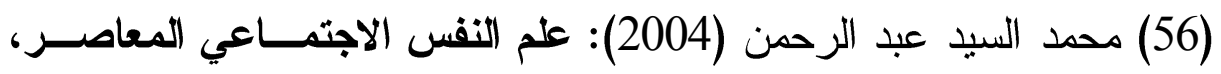

$$
\text { مدخل معرفي • ( القاهرة : دار الفكر العربي ). }
$$

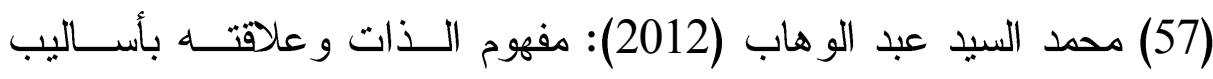

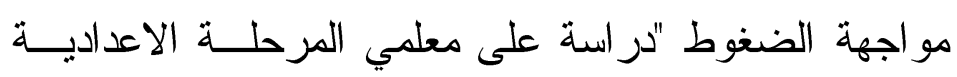


بمحافظة قنا" مجلة دراسات نفسية المجلـــ (22)، ع (1)،

$$
.148-105
$$

(58) محمد الصافي عبد الكريم (2010): أحداث الحياة الضاغطة وعلاقتهــا بالإغتراب النفسي لطلاب الجامعة المؤتمر السنوي الخامس

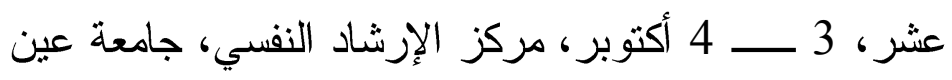

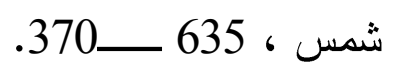

(59) محمد حسن أبو رأسين (2012): فعالية برنامج تدريبي مقترح لتحسين

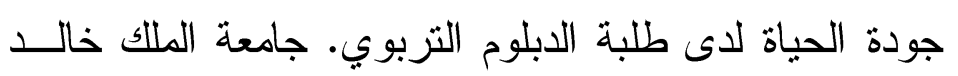

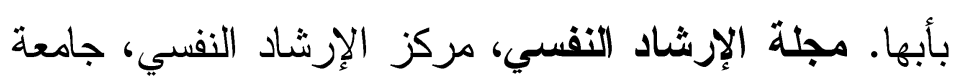

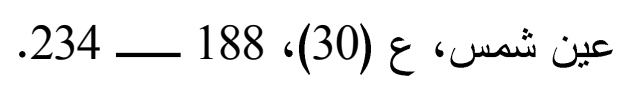

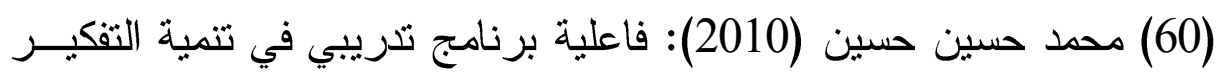

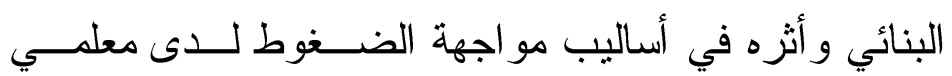
المرحلة الابتدائية. مجلة دراسات تربوية و إجتماعية، مصر ،

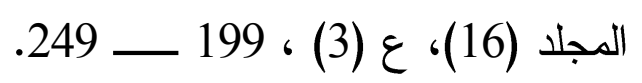

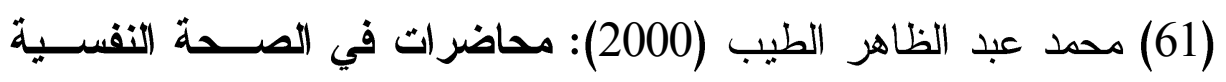

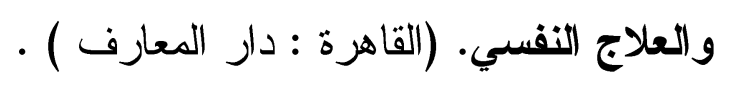

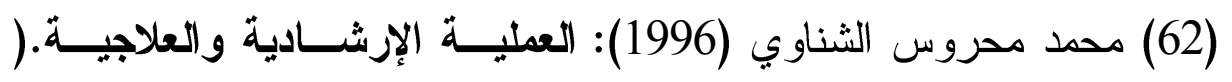

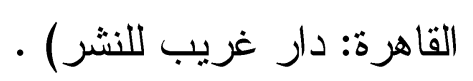

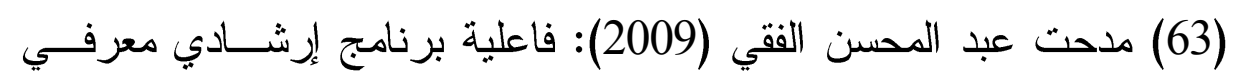

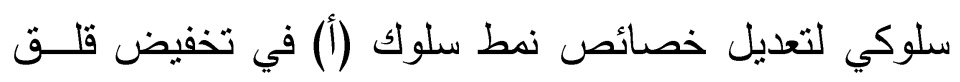

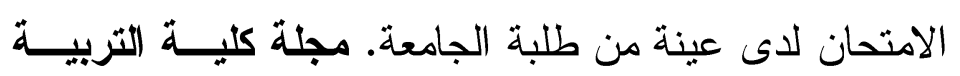

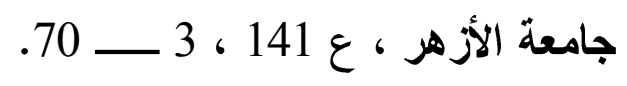


(64) محمود عبد الحليم منسي و علي مهذي كاظم (2006): مقيــاس جــودة الحياة لطلبة الجامعة ، ندوة علم النفس وجودة الحياة، جامعة

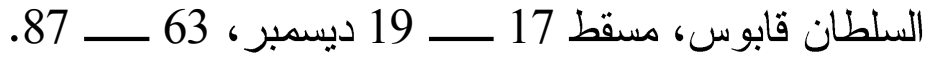
(2010): تطوير وتقنين مقياس جودة الحياة لدى طلبة الجامعة مابطة

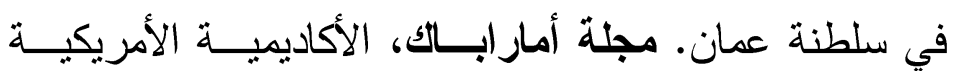

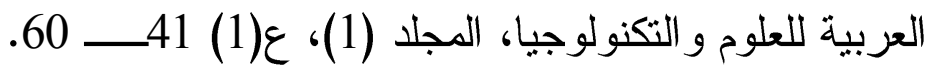

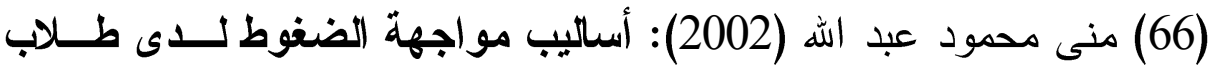

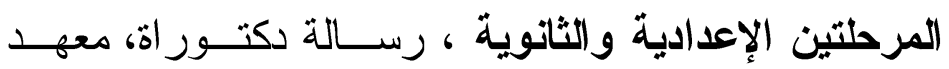
الدر اسات و الطفولة، جامعة عين شمس، القاهرة.

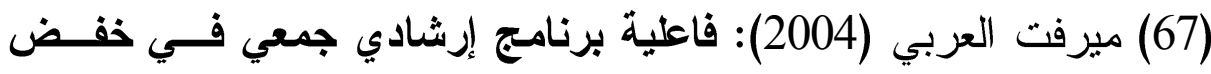

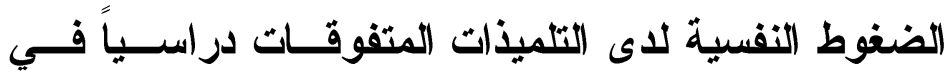
الصف التاسع من التعليم الأساسي في مدينة تعز ـ اليمن. (68) نايف فدعوس حمد (2012): فاعلية برنامج إرشادي جماعي في مو اجهة

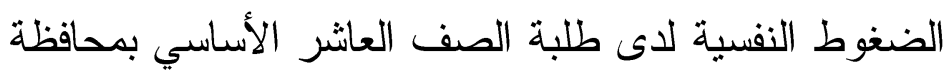
المفرق في الأردن. مجلة جامعة القدس المفتوحة للأبحاث

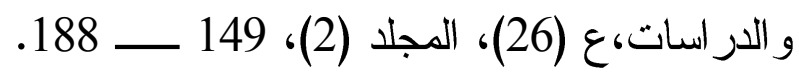
(69) نظمي أبو مصطفى ونجاح السميري (2007): علاقة الأحداث الضاغطة

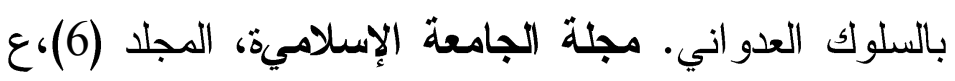

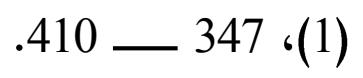

(70) نعيمة جمال الرفاعي (2004): مستوى تحقيق الذات في علاقته بأساليب

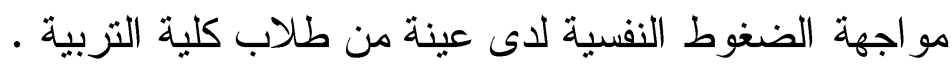

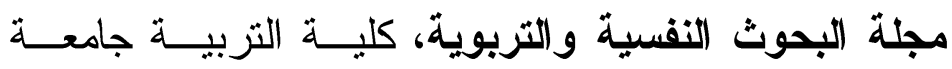

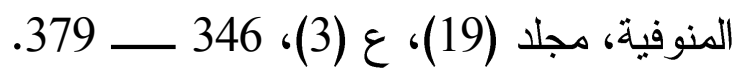


(71) نو ال عبد اللطيف يس (2001): الضغوط النفسية وعلاقتها بالتحصيل

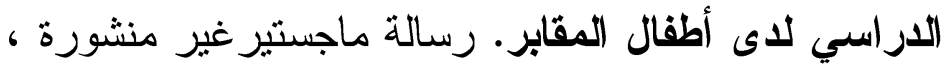

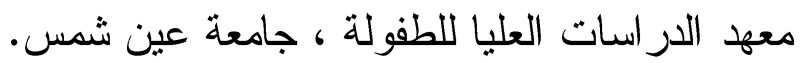

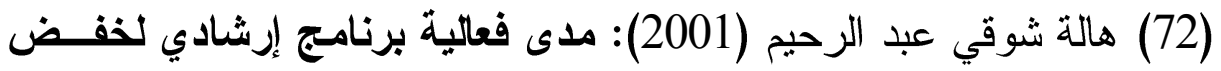

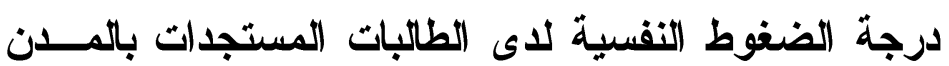

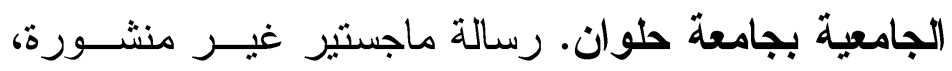
معهر الدر اسات العليا للطفولة، جامعة عين شمس. (73) هانم مصطفى محمد (2009): تحسين جودة حياة الطالــب بإســتخدام برنامج إرشادي قائم على نظرية الإختيار ـ مجلة كلية التربية

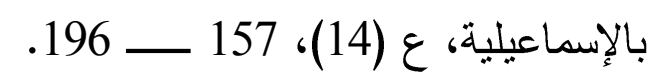
(74) هشام إير اهيم عبد الله (2008): جودة الحياة لاى عينة من الراشــدين

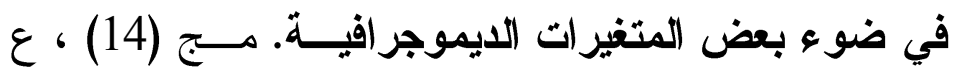
180 - 139 ـ 180

(75) هناء أحمد محمد (2011): العلاقة بين ممارسة نموذج الحياة في خدمسـة

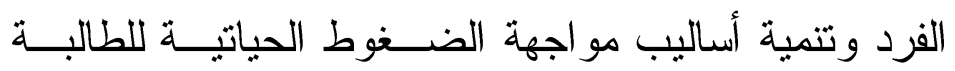

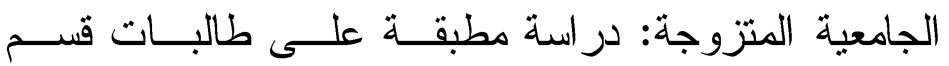

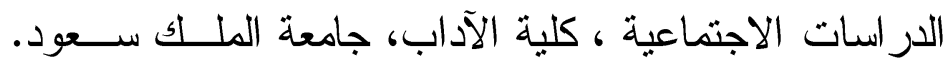
مجلة دراسات في الخدمة الاجتماعية والعظوم الأســانية،

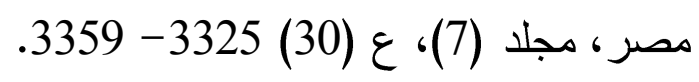

(76) هند سليم محمد (2008): جودة الحياة وعلاقتها بالرهاب الإجتمــاعي

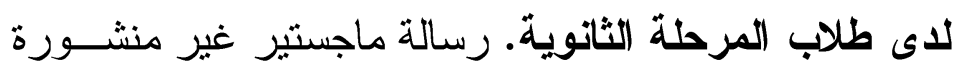
كلية التزبية، جامعة حلو ان.

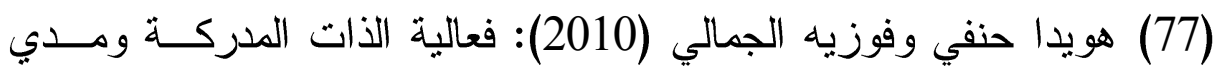
تأثثير ها علي جودة الحياة لدي طلبة الجامعة من المتفــوقين 
و المتعثرين در اسياً . مجلة أمار اباك ، الأكاديمية الأمريكيــة

العربية للعلوم و التكنولوجيا، المجلد الأول ، ع (1) ، 61 -

.115

(78) وحيد مصطفى كامل (2005): فعالية برنامج إرشادي عقلاني في خفض

أحداث الحياة الضاغطة لاى عينة من طلبة الجامعة. مجلــة

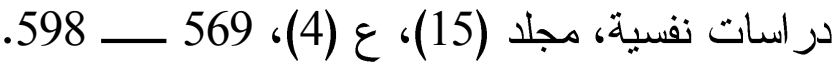

(79) وصل الله عبداله السواطـو غالب المشـيخي (2011) : أثـــر برنــامج

إرشادي في التكيف مس الحياة الجامعية لدي الطلاب المســتجدين

بجامعة الطائف ـ مجلة كلية التربية ، جامعة الأزهر ، ع ع ( 145 ،

$$
\begin{aligned}
& \text {.569- } 515 \text { ، ( } \\
& \text { ثانياً : المراجع الاجنبية }
\end{aligned}
$$

(80) Anctil, T., Mccubbin, L., O`Brien, K., Pecora, P.\& Anderson, H. (2007): Predictors of adult quality of life for foster care alumni with physical and or Psychiatric disabilities child abuse \& Neglect: The internatronal journal,Vol. (31), (10), 1078 - 1100.

( 81 ) Beasley, M., Thompson, T. \& Davidson, J. (2003): Resilience in res ponse to life stress: The effects of coping style and cognitive hardiness. Journal of personality and individanl differences. Vol. 36, 1387-1402.

(82) Berry, L.M. (1998): Psychology at work, an introduction to indnstrial and organizational psychology. $2^{\text {nd }}($ Ed). MebrawHill, New yourk.

(83) Chan, D. (2003): Hardiness and its role in stress - burnout relationship among prespective chinese teachers in Hong Kong. Journal of teaching and teacher education.vol .(2), 3 .

(84) Chen, L. \& Kennedy,C. (2005): culfural variations in children's coping behavior, T.V. viewing Times-and family functioning. Journal of international nursing Keview, vol (52) (3).

(85) Constance, H. (2004): Intergenerational trans mission of depression test of an interpersonal s tress model in a community sample. Journal of counseling and clinical Psychology, vol. 72 (3), 511-522. 
(86) Corey, C. (2000): Groups: Process and practice. Cali for Brook publis hing company.

(87) Corey, G. (2008): Therapy and practice of Group counseling Australia, Thomson. Brooks Company.

(88) Edwards, L. \& Romero, A. (2008): coping with discrimina among Mexican descent adolescents. His panic . journal of behavioural science, vol. (30) (1),145 .

(89) Eliss, A. (2000): Rational-Emotive behavior the ropy in R.J. corsini and D. wedding, edcurrent. Journal of counsel and de velopment, vol. 71, 222-320.

(90) Fortes, L., et, al. (2006): Health and disability work -re late stress and wellbeing, The roles of direct action coping and palliative Coping . scandinavian Journal of psychology, vol. (47) (4), 293.

(91) Folkman, s.s. (1998): Positive psychological states and coping with se vere stress. journal of Psychology, Starn, vol.(45) 68 .

(92) Gavala, J. (2005): Influe ntial factors moderating acade mia enjoyment and psychological well-being for Moon university students at Masses university New Zeland. Jouranal of ps ychology, 34 (1), 52-65.

(93) geffery, P. (2007): Negative life events, patterns of positive and negative religious coping, and psychological functioning. Journal of the scientific study of religion, vol. (46) (2), 159-167.

(94) Giradano, D., Everly, G.\& Duesk, D. (1997): controfing stress and tension. Allyn and Bacon, $5^{\text {th }}$ Ed, Boston.

(95) Glasser, w. (1997): A new look at school failure and school success (cover story). Phi Delta Kappan, Jouranal of psychology, vol. (78) (8), 596-603.

(96) Glasser, w. (1998): choice theory: A new psychology of personal free dom. New york, Harper Collins.

(97) Goode, D. (1994): Quality of life for Persons with disabilikes International prespectives and iss ues in Mitchel. $D$. (1997): Book Review: Journal of International \& de velopment disability.

(98) Heiman, T. (2004): Examination of the salutogenice model, support resources, coping style, and stress among Israeli unive rsity students. Journal of psychology, vol. (138) (6), 505-520.

(99) Jia, H., uphold, C.R., Wu, S., Reid, K., Findley, K.\& D. W. (2004): Health-Related. Quality of life among men with Hiv infection: Effects of social support, coping and 
depperssion AIDS patient care \& STDS, Jouranal of psychology, vol. (18) (10), 594-603.

(100) Kao, C. (2005): Reaction to stress: social support and coping startgies of early childhood teacher.Spalding University.

(101) Lawler, C., ouime tte, P. \& Dahlstedt, D. (2005): posttraumatic stress symptoms, coping, and physical health status among university students seeking health care, Journal of traumatic stress, vol. (6), 741-750.

(102) Lawaski, Y. (2007): leisure and quality of life in an international and multicultural context: what are major path ways link leisure to quality of life, social Indicators research, vol. (82) (2) 233-264.

(103) Litman, J. (2006): The cope inventory: Dimensionality and relationships with approach and avoidance - motives and positive negative traits. Journal of Personality and individual differences ,vol. 41, 273-284.

(104) Longest, J. (2008): Quality of life impact on mental health needs. New York, Institute of education science.

(105) Mac Namara, S. (2000): stress in young people- what It's new and what can we do?. London: continuum.

(106) Marc, D. (2000): Health ps ychology. Theory, Research and practice. London: sage publication.

(107) Mark, v., chery L, G., Cheryl, K., carl, T. \& John, K. (2002): Maladaptive coping strategies in relation to quality of life among HIV+Adults, Aids and Behaviour, Jouranal of psychology, vol. (6) (1), 97-106.

(108) Moeini, B., shafii, F., Hidarnia, A., Baboif, G., Birashk, B.\& Alleh Verdi pour, H. (2008): perceived stress, self-efficacy and its relations to psychologyical well-being status in Iranian male high school students. Social behavior and pe rs onality, vol. (36) (2), 257-266.

(109) Moran, C. \& Hughes, L. (2006): coping with stress: social work student and Humour. Journal of social work education, vol. (25) (5), 501-517.

(110) Murphy, H. \& Murphy, E. (2006): comparing quality of life using the world health organization quality of life measure ( wHo)

(1-100) in a clinical and social functioning, journal of mental health, vol. 15 (3): 289-300.

(111) Oleakan, M. (2004): stress management strategies of secondary school principals in Uige ria. Educational Research, vol. (46) (2), 105-207.

(112) Orte, C., March, M. \& vives, M., (2007): social support Quality of life, and university Programs for seniors. Journal of Education ge rontology, vol. (33) (11), 995-1013.

doi : $10.12816 / 0001050$ 
مجلة (الدراسات التربوية و الاسنية ـ كلية التربية ـ جامعة دمنهور - المجلد الذامس العدد (1) لسنة 2013

(113) Patterson, C. H (1997): psychology abiopsychosocial approach Addison Wesley. Educational publisher Inc., New York.

(114) Ring, L., Hofer, s., Mcgee, H., Hickey, A. \& o boyle c , (2007): Individual quality of life: can it be accounted for by psychological or subjective well-being. Social Indicoors Research, vol. (82) (3) 443-461.

(115) Rogerson, R.J. (1999): Quality of life and city compe titveness: urban studies, Social Indicoors Research, vol. 36, 969-986.

(116) Sarafrino, E.P. (1994): Health psychology: Biopsy chological Inte raction. $2^{\text {nd }}$ Ed, New York: John willy and Sons.

(117) Shalock, R., L. (2004): The concept of quality of life: what we know and do not know. Journal of Intellectual disability research, vol. (48) (3), 203-216.

(118) Schmidt, S. \& Power, M., (2006): cross-cultural analyses of determinants of quality and mental health, Results from the eurohis study, Social Indicators Research, vol. (77) (1), 95-138.

(119) Shek, D., lee, T. (2007): family life quality and emotional quality of life in chinese adolescents with and without economic disadvantage, Social Indicators Research, vol. (80) (2), 393-410.

(120) Sirgy, M., J., Dennis cole, Rustan, H., lee meadw, D., Regt Z, M. your surat, D. (1995): A life satisfaction measure. New Jersey, Percent.Ue-Hall.

(121) Speck, B. (1999): defining stress as ethical conflict. Bullet in of the Association for business communication. Vol. (56) (1), 34-37.

(122) Teichmann , M., (2006) : Spiritualneeds and Quality of life in Estonia. Social Indicators Research, vol. ( 76) , 147163.

(123) Ventegodt, S., Andersen, N.J. (2003): quality of life theory I.

The IQ OL theory: An Integrative theory of the global quality of life concept. The scientific: world Journal 3: 1030-1040.

(124) Wang, J. (2010) : Quality of life associacted with perceived stigma and discrimination amang the floating population in Shang hai- china : A Qualitative study, Oxford university press .

(125) Yu, Grace, B. \& Lee, D. (2008): A model of quality of college life of students in korea, Social Indicators Research, vol. (87) (2), 269-285. 


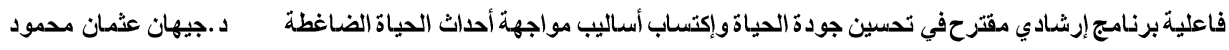

(126) Zhang, L. (2007): Teaching styles and occupational among chinese university faculty members. Journal of Educational Psychology, vol. (27) (6), 823-837. 